\title{
14 Ekphrasis of a manuscript (MS London, British Library, Or. 12070). Is the "London Physiognomy" a fake or a "semi-fake," and is it a witness to the Secret of Secrets (Sirr al-Asrār) or to one of its sources?
}

The London Physiognomy, purportedly the oldest written witness of the Physiognomy chapter of the Sirr al-Asrār, entered the collections of the British Museum in 1954. ${ }^{1}$ Lacking any explicit reference to a wider text bearing the title Sirr al-Asrār, it was nevertheless later regarded by Manzalaoui as a witness of a 'mixed recension' of the Sirr al-Asrār, showing features of both the two main recensions preserved today. ${ }^{2}$ Grignaschi on his side regarded the London manuscript as a valuable witness, placing it higher in his own reconstruction of the transmission than Manzalaoui. ${ }^{3}$ The colophon which concludes that text indicates that the copy was made during the first half of the tenth-century, implying that the London Physiognomy may be the oldest preserved witness of a chapter of the Sirr al-Asrār.

To this day, the London manuscript has never been described in any of the British Library catalogues (the British Library is where the collections of the British Museum were relocated in 1982), and the so-called recent acquisitions are merely listed in a register available to the public in the Oriental Manuscripts reading room. After Meredith-Owens's initial enthusiasm regarding the acquisition of what would have been one of the oldest Arabic manuscripts on paper in the United Kingdom, specialists started to raise suspicion as to the actual date of the manuscript. ${ }^{4}$ Curators at the British Library now consider the manuscript to be a "fake, stemming from a famous forgers' atelier active in Tehran in the 1940s," according

1 Meredith-Owens 1955-1956, 33-34. Foster 2006, 14-16.

2 Manzalaoui 1974, 147-257; on the London Physiognomy, see esp. 155, 187 and 233-234. Manzalaoui distinguishes a Short Form (SF) in seven or eight books (SF7 and SF8) and a Long Form (LF) in ten books where Steele had used the designation of 'Western version' for SF and 'Eastern version' for LF (Steele, Secretum Secretorum, p. xiv, explaining that he did not believe in a Western origin for the composition of the text but wanted to underline the fact that the version was available in the West, as witnessed by the excerpts translated into Latin by John of Sevilla as well as by the Hebrew and Spanish translations).

3 Grignaschi 1976, 14.

4 Walzer 1985, 26, expressed the strongest judgement of the London manuscript, which he considered a forgery, in a very brief remark. However, the articles of Stern which Walzer quotes to support his assertion (loc. cit., 25, n.50) are wrongly designated (read Stern [9] and [10] instead of [8] and [9]) and nowhere do we find in them Stern expressing the positions ascribed to him by Walzer. 
to the hand-written note on the list of acquisitions found in the margin of the entry "Or. 12070." 5 This unsupported remark is based on the assumption that the paper is younger than the purported date of the copy. Nonetheless, as the detailed investigation in this essay will seek to establish, a number of details seem to point to the manuscript as a 'semi-fake' rather than a 'fake'. ${ }^{6}$

\title{
Codicology to the rescue of text-analysis?
}

The manuscript and its contents were briefly described by Manzalaoui in his 1974 study of the manuscripts and sources of the Sirr al-asrār as follows:

\begin{abstract}
Angular naskhī, extremely reminiscent of Kufic, with idiosyncratic forms to certain letters. Dated, in the scribe's own hand, 330 A.H., i.e. 941 A.D. Thick pinkish paper. A 43 fol. octavo-sized manuscript. Our text is the last of six short tracts; fols. 39v-43; 18 1l. [...] Other contents: (1) Epistle of Fārābī in comment upon epistle of Zeno (this manuscript antedates Fārābī’s death by nine years). (2) Miscellaneous extracts from the pseudo-Aristotelian Problemata. (3) Treatise by the grammarian al-Kisā'ī on common blunders in speaking Arabic. (4) Epitome of Plato's De legibus, made by Ḥunayn ibn Isḥāq. (5) Minor items from the Hippocratic collection, including the letter of Artaxerxes to Hippocrates. ${ }^{7}$
\end{abstract}

5 Grignaschi's correspondent at the British Museum, whom he quotes as "E. Anderson” expressed his doubts on the paper and the writing already in 1976 (see Grignaschi 1976, 14). The register's note was communicated to me by the curator of Arabic manuscripts at the British Library, Colin Baker, when I started working on the manuscript in 2009 and whom I thank here wholeheartedly. Further details were added in an e-mail (dated November, 23rd, 2009) by David Jacobs, an expert on Arabic papers at the British Library, who stated that the Or. 12070 is written on "an Indian dyed paper, common in the 19th and 20th c."; Savage-Smith 2003, introd. xli-xlii, n. 123, refers to the origins of the London manuscript as a fake produced in Tehran in the 1940s, without explicit reference to the register.

6 This notion is developed, in relation to Arabic and Persian manuscripts, in Soudavar 1999, 255-273. 7 Manzalaoui 1974, 155-156, to which should be added the following: modern binding added at the British Museum, traces of restauration; size 27, 5 by $18 \mathrm{~cm}$; writing surface 23 by $14 \mathrm{~cm}$; 18 lines per page. Manzalaoui was almost correct in his description, but for the qualification of 'minor' item he gave to the Pseudo-Hippocratic Letters, here extant in a unique complete Arabic translation and followed by two Hippocratic short pieces known to have been translated by Hunayn b. Ishāq (see E. Cottrell, "An Arabic Manuscript of the Pseudo-Hippocratic Letters," forthcoming in the proceedings of the XXIXth International Conference on the History of Arabic Sciences [University of Aleppo, $3^{\text {rd }}-5$ th Nov. 2009], in press and available on http://fu-berlin.academia.edu/EmilyCottrell). As to the Platonic "Laws" which are here stated to be given according to a translation by Ḥunayn ibn Ishāâ, they should rather be called pseudo-Platonic, see Gutas 2012, 852-853 and the edition of the text by G. Tamer (see infra fn. 22). 
According to a brief remark by Manzalaoui, the seller was a man named "P. Khonsavi". 8 This scholar is likely to be the same person who sold a copy of the Druze epistles to the Bodleian library in 1956 (Oxford, Bodleian, MS Arab. e. 213), the writing of which closely resembles the London manuscript as was remarked by Alfred Felix Landon Beeston, then curator of Arabic manuscripts at the Bodleian. ${ }^{9}$ The London and Oxford manuscripts show a number of common features, not limited to their script. They both betray the use of Eastern Kufic headings and the claim that they were copied during the lifetime of the main author - Fārābī in the case of London manuscript and Hamza b. 'Ali, the supposed founder of the Druze religion, in the case of the Oxford codex, which purports to be an autograph. ${ }^{10}$ Claims like this would have enhanced the price of the manuscripts and they may raise suspicions.

More problematic is the time span between the dates of the two manuscripts as given in their colophons: $330 \mathrm{AH} / 941-942 \mathrm{CE}$ for the London specimen; 408 AH/1017-18 CE for the Oxford one, making the possibility of an autograph, or that of a single copyist for both manuscripts, very unlikely. ${ }^{11}$ Be that as it may, Beeston seemed convinced of the authenticity of the Druze manuscript after he compared the supposed signature, on the top of the first folio, allegedly that of the famous Abbasid vizier, Muhammad Ibn al-'Alqamī (d. $656 \mathrm{AH} / 1258 \mathrm{CE}$ ), with the identical mark preserved on an Istanbul manuscript of Marzūbānī's Kitāb al-Muwashsha. ${ }^{12}$ The vizier

8 Manzalaoui 1974, 155. The spelling 'Khonsavi' should certainly be corrected into Khonsari.

9 Beeston 1954-1956, 285-290, see 287. I am extremely grateful to the authorities of the Bodleian Library in Oxford for providing researchers the precise conditions of acquisitions of the manuscripts in their possession and in particular to Alasdair Watson (Bodleian Library) for having checked the acquisitions register. The sale was concluded by "S. Khonsari, from Dublin, on the 13th of February, 1956."

10 The Oxford copy was used by De Smet for his critical edition of the Druze epistles (De Smet 2012). On the complex issue of the beginnings of the Druze religion, see De Smet 2012, 19-30. A number of the folios carrying the Eastern Kufic headings at the beginning of treatises in the Oxford manuscript have disappeared and were probably sold independently.

11 For the little we know about him, Hamza ibn 'Ali was not yet born in 330/941-2. De Smet makes the following remarks about the Oxford manuscript: (1) the date appears in a note by a later hand, (2) the text is generally faulty, (3) many folios are missing and (4) that the existing folios have been bound with some disorder (cf. De Smet, loc. cit., pp. 115-116 and p. 550, n. 37). He adds that the Oxford manuscript shares some of its readings with a manuscript of the Druze epistles now preserved in Saint-Petersburg (a facsimile edition of which was produced by Rodionov 1995) which is believed to be from the 16th century. This latter manuscript was offered by the French physician Clot Bey to the tsar Nicolas I in 1839 (De Smet 2012, 115). Clot Bey was attached to the khedive Muhammad 'Alī and he had come into possession of dozens of Druze manuscripts after the Druze revolt of 1838 was put to an end by the Egyptian army (De Smet 2012, 12, 107-109).

12 Some folios of the Istanbul manuscript (MS Suleymaniyye, Cami 1012) were made available on a private website (of which screenshots can be sent on request to the author of this paper). The supposed signature of Muhammad ibn al-'Alqāmī seems at first sight close enough to the one appearing on the Oxford manuscript, but we may wonder why a vizier would not rather have a seal or a more calligraphic ex-libris, and why the honorific name (laqab) bestowed on him by the caliph, namely 
al-'Alqāmī (or Ibn al-'Alqāmī, but the first form is the one used by his contemporary and colleague Nașīr al-Dīn Tūsī) survived the death of the last Abbasid caliph and entered the service of the Mongols. The existence of his books in a Turkish library would imply that an Ottoman librarian knew the provenance of the book (possibly as part of a group of books), or that we are dealing with a facsimile of a work once possessed by al-'Alqāmī. Needless to say, the possibility that the signature of the famous vizier was added by a clever book-seller at any stage of the history of the manuscript should also be taken into consideration. All things considered, too little is known of the Istanbul manuscript to take it as evidence for the date of the Oxford manuscript.

Returning to the London manuscript, the semi-Kufic script and Eastern Kufic headings may agree with a reference to Mashhad on the end fly-leaf of the original binding (now fol. 43r), pointing to a provenance from the Eastern part of the Abbasid empire, as will be discussed more extensively in the next section. This was indeed the period during which semi-Kufic evolved towards a formalized form of Naskh script, the characteristics of which were codified by Ibn Muqla (d. 940 CE). ${ }^{13}$ But as already emphasized above, the script of the London and Oxford manuscripts being so peculiar and apparently related, it seems unlikely that one text could have been copied in Mashhad or elsewhere in Iran by Muhammad ibn 'Alī ibn Durustawayh al-Isbāhānī ("of Isfahan") while the other could be the work of the sketchy figure of Hamza ibn 'Ali b. Aḥmad al-Zawzānī at the Fatimid court in Cairo some seventy years later. ${ }^{14}$ Interestingly, the London manuscript collection bears the title Epistles of the Sages (Rasẩ $i l$ al-hukamā'), using the title of the Pseudo-Hippocratic Letters as a generic title for the whole volume. ${ }^{15}$ This title is reminiscent of the way the Druze epistles are usually designated, as Epistles of Wisdom (Rasâ'il al-ḥikma), although the Oxford manuscript lacks the title, which De Smet believes was only later attached to the Druze epistles.

\footnotetext{
“Mu’ayyid al-Dīn,” i.e. 'Supporter of Religion,' was not used. According to De Smet (2012, 116, n. 501), the Istanbul manuscript was copied in 637/1239 for the vizier's library (as stated on the title page). De Smet seems to be willing to give some credit to the signature of al-'Alqamī, making the Oxford copy the oldest known manuscript of the Druze epistles. However, the late hand who added on the first folio the mention that the copy was "made" for the vizier's library must be mistaken: al-Alqami's was named vizier in 639/1242, three years after after the purported copy of the Istanbul manuscript. For a full discussion of the relevant sources, cf. Jorati 2014 and Wickens 1962, 23-35. On a closer examination, the hand which wrote "Muhammad ibn al-Alqāmī" on two folios of the Druze manuscript (at the beginning of two epistles, on fol. $1 \mathrm{r}$ and 44r) seems to differ slightly from the one responsible for the signature on the front page of the Istanbul manuscript, but this point should be ascertained by an expert in paleography.

13 Tabbaa 1991, 119-148. The Niffarī Eastern Kufic manuscript dated 344/955-6, in Arberry 1953, 29-42, is also discussed by George 2010, 126.

14 Hamza b. 'Alī purportedly wrote his treatises and letters at the Fatimid court in Cairo, although he supposedly stemmed from far-away Sijistān (modern Baluchestan).

15 I am currently working at an edition and translation of this important text with the collaboration of Prof. Sayyed Gad (Tanta University).
} 
In regard to the reference to the city of Mashhad in Khorasan (here given its honorific name Mashhad al-Riḍā from its association with the Twelver Shiite imam al-Riḍā), ${ }^{16}$ the London manuscript seems to present two stages of completion. In one colophon, corresponding to the treatises copied in the angular Naskh script inspired from semi-Kufic and coming at the end of the Physiognomy (the last in the collection of treatises in the manuscript), we read: "Muhammad ibn 'Ali ibn Durustawayh of Isfahan has achieved this copy in 330 [AH. i.e. 941-942 CE], praise be to God for his blessings and the prayer on [the prophet] Muhammad and his pure family (farigha min ta'līqihi Muhammad ibn 'Alì ibn Durustawayh al-Ișbāhānī sanat thalathīn wa thalathimi'a, wa-l-ḥamdu li-Llāhi 'alā ni'amihi wa-l- șalūt ${ }^{17}$ 'alā Muhammad wa-ālihi al-țāhirinn)" (Or. 12070, fol. 43r). But on the verso of the same folio, we find in what seems to be a different and later hand using the Muhaqqaq script an indication as to the location of the copy of a poem ${ }^{18}$ written on what was probably the cover of the quire or booklet before it was rebound in London: "It was written as a memory for the owner of the book, Muhammad ibn Ibrāhīm the Persian, in [the city] of Mashhad al-Rị̣ā (katabahu tadhkiratan li-șāhib al-kitāb Muhammad ibn Ibrāhīm al-Fārisī fī Mashhad al-Ridīa)" (Or. 12070, fol. 43v). ${ }^{19}$ The script of the poem, like that of the table of contents (in Persian) on fol. 1r, by an even later hand, does not seem to claim any old age, two points which tend to oppose the idea of a forgery. The copyist of the poem points to the otherwise unknown Muhammad ibn Ibrāhīm al-Fārisī as the owner, possibly the commissioner of the book.

More intriguing though are the reader marks left by an owner of the London manuscript on fol. 2r and 16r. The man, whose name could be read Abū al-Hasan 'Alī b. Muhammad al-Farā’inī/al-Qarā'inī/al-Qarānsī/al-Qurāshī, gives the date of $650(\mathrm{AH}$, equivalent to 1252-53 CE) in the top left corner of fol. 2 r. This would contradict the informed view of Dr David Jacobs (British Library) who estimated that the "Indian dyed" paper on which the London Physiognomy is copied belongs to the common

16 Al-Ridā died in Mashhad in 808. It is unclear to me when exactly the Shiite imam's name came to be attached to the city.

17 The use of the old orthography for șalāt is common in religious formulas, including in later or modern manuscripts. But the London manuscrit displays the use of old orthography in several places throughout its texts and not solely in religious formulas (cf. infra Table 1, especially fn. 2). This feature adds some credit to the age of the texts copied in the London collection.

18 The verses belong to a poem composed while in prison by 'Alī ibn Jahm (whose name is given on the top of the page) in honour of the caliph al-Mutawakkil (r. 847-861). It appears in the collection of his poems as edited by Mardam Bak, Dīwān 'Alī ibn al-Jahm, 43-45.

19 Pointing to the possibility that the London manuscript is a recent copy of an older artefact, the ink of fol. 43r (and 42r) has transperced through fol. 43 and left a reddish trace of the text on the modern binding folio 44r, otherwise left blank. The (metallic?) ink of the poem on fol. 43v seems to have hindered the chemical reaction: the text of $43 \mathrm{v}$ appears as a shadow within the reddish trace of $42 \mathrm{r}$ and 43r on 44r. Dating the ink used for the manuscript would certainly help piercing the mysteries of the London manuscript. 


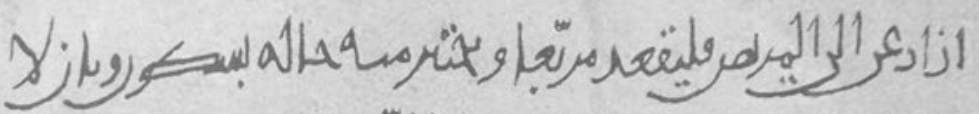

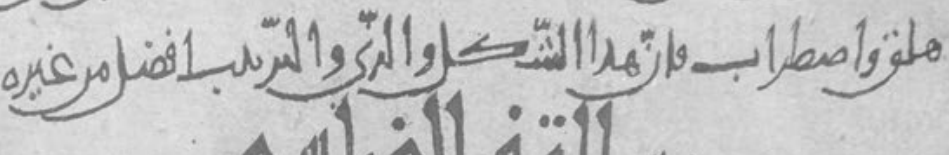
sill

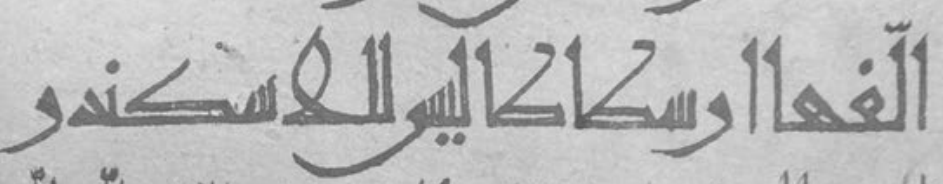

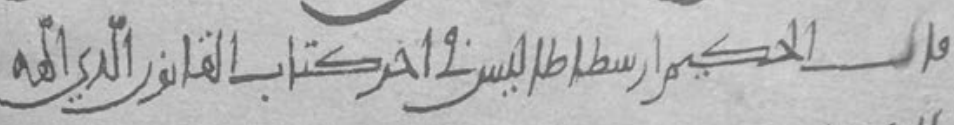
isiols

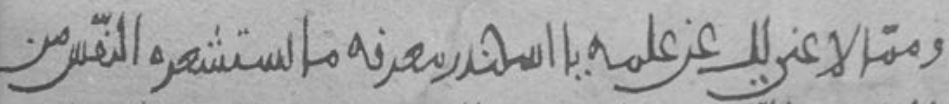
-

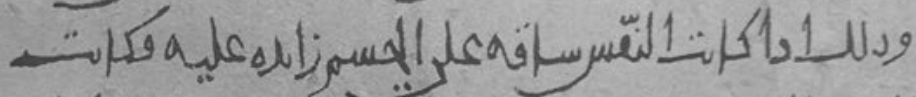

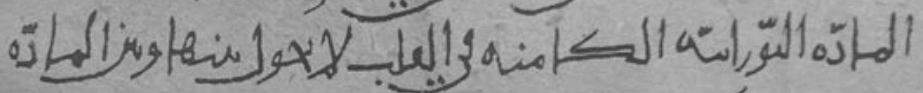

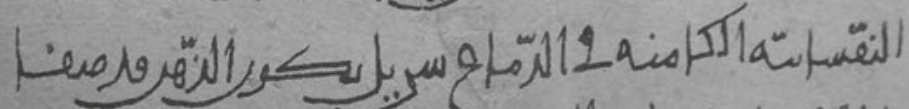

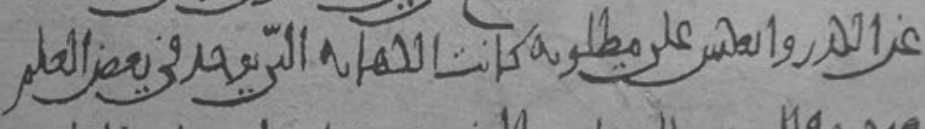

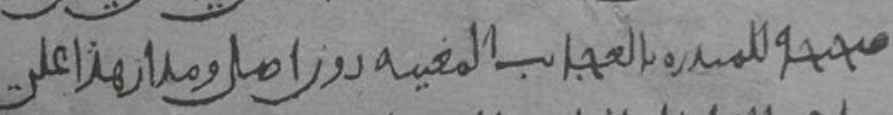

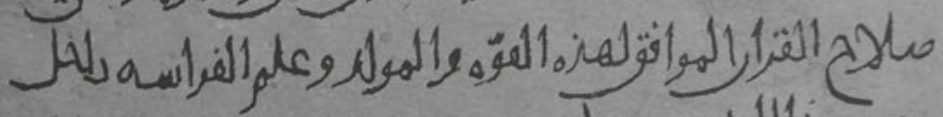

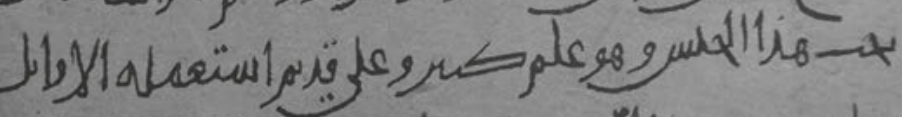

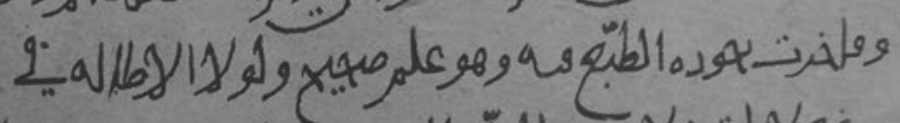

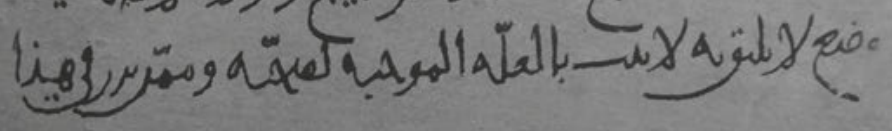

First page of the Treatise on Physiognomy (London, BL, Or. 12070, fol. 39b). Courtesy of the British Library. 
type of these papers known for the 19th and 20th c. dyed papers. ${ }^{20}$ The (purported) thirteenth-century reader's mark, as well as others readers' marks in the manuscript, seem influenced by the Nasta'liq type of script, which did not develop until the 13th14th century. ${ }^{21}$ The great diversity of scripts displayed in the London manuscript is among the reasons why it can be suspected of being a forgery.

Inconclusive as the evidence is, the above description offers a number of hints which specialists will have to examine in order to establish a history of the London manuscript (and possibly that of the Oxford Druze epistles). The question of the authenticity of the London manuscript can be reduced to three alternatives:

1) The London manuscript was copied by the same hand as the Oxford manuscript, and the papers and inks should be analyzed with radiocarbon dating and multispectral imaging in order to determine their age more precisely. It should nevertheless be remarked that in the case of a forgery, both manuscripts could well have been copied on sheets of paper of a respectable age to enhance the value of the manuscript.

2) The London manuscript was copied by someone who made use of the Oxford manuscript, with the intention of imitating the hand.

3) The London manuscript is a facsimile of an original copied by the same hand as the Oxford manuscript.

Whichever of these three hypotheses is the correct answer, it seems clear that the London and the Oxford manuscripts were once part of a unique collection, remembering that they were obtained from a unique seller. The presence of a Druze manuscript in this collection is a significant hint that a Druze or someone interested in Druze writings has shown interest in the texts assembled in the London manuscript. A cursory presentation of the contents of the manuscript will confirm that the pieces in the manuscript were in all probability not assembled randomly.

\section{An overview of the contents of the London manuscript}

The epistles included in the London manuscript are all known, though only partially in a number of cases, from other manuscripts. They can generally be said to offer a fairly correct text, albeit often an abbreviated or fragmentary one. ${ }^{22}$ The main title given to the

20 As was kindly pointed out to me by Dr Jacobs (cf. supra fn. 5), Indian papers go back to earlier times, with the earliest known dated specimen fabricated in Nepal in 1105 CE.

21 See the reproduction in Beeston, (supra fn. 9), plate XVII.

22 Apart from Manzalaoui's description quoted above, the London manuscript was described with more detailed identifications by Daiber (2009, 163-165). The Fārābī treatise was first edited in Hyderabad 
booklet, appearing on folio 2r, refers to two distinct items: "Epistle of the shaykh, the ascetic, Abū Nașr Muḥammad ibn Ṭarkhān al-Fārābī may God prolong his life and Epistles of the Sages (Risālat al-shaykh al-zāhid Abū Nașr Muhammad ibn Tarkhān al-Fārābī ațāla Llāhu baqā'ahu wa-Rasā'il al-hukamā')". The Farabian epistle (dealing with the definition of the "Necessary Being") is clearly seen as the most valuable piece in the collection, and the claim that the text was copied during the author's life-time gives an added value to the text. The absence of a more elaborate title might be explained by the fact that the Fārābī's treatise opening the collection on the next folio starts abruptly, in a manner not uncommon in the Middle Ages where books' titles were often deduced from the first lines of the text. The minor treatises are not mentioned on the title page, but strangely enough the little-known work here designated as Epistles of the Sages (i.e. the title given here to the Pseudo-Hippocratic Letters) is mentioned, following the form we find at the beginning of the text on fol. 33r. This, as was suggested earlier, might be related with the buyer or commissioner's interest for some epistles on "wisdom (hikma)."

Because of the parallels which have been noticed between Fārābī's works and the Sirr al-Asrār, we should probably give a short overview of the Farabian material in the London manuscript. ${ }^{23}$ As was mentioned above, the formula attached to Fārābī's name implies that the copyist knew he was alive at the time he completed his work (some eight years before Fārābī's supposed death in Syria in 339 AH/950 CE). Even if such a note could also have been added to enhance the price of a manuscript, the existence of al-Fārābī's Commentary on Zeno's Epistle happens to be attested in twelfth-century Khorasan by the second-generation Avicennian philosopher Zahīr al-Dīn al-Bayhaqī (d. $1165 \mathrm{CE}$ ), the author of one of the earliest biographies of al-Fārābì that includes a bibliography. ${ }^{24}$ This might in turn point to the text as having been written by Fārābì

(1349/1930) and reprinted several times, including Sezgin 1999, 225-234. The lexicographical treatise of al-Kisā̄î (d. 189/805) was published by Brockelmann 1898, 29-46. For the partly pseudepigraphous Aristotelian questions and answers on the model "Why is it that? (li-mā șāra)" see Filius 1999, esp. xliii-xliv where the author gives a number of parallels from Abū Bakr al-Rāzī's Kitāb al-Hiāwĩ (whose influence on the Sirr al-Asrār's Physiognomy chapter is addressed in R. Forster's paper in this volume). For more Problemata including literal parallels to the London manuscript, in a version ascribed to Rāzī under the title "Medical questions (masāil țibbiyya)" see the MS Leiden, Or. 958, foll. 39r-45v, where the set of questions follows directly a chapter on onomancy known from the Sirr al-Asrār (see infra part II.3). For the Pseudo-Platonic Laws, cf. Tamer 2001, 68, n. 27 and 290; 2004, 303-335 (using the London Manuscript). 23 These parallels remain one of the most difficult issues in adressing the Sirr. The date of the Sirr is usually established on the basis of the parallels with the Brethren of Purity, but the date of their Epistles is still debated, and so is the nature of their relation to both Fārābī's writings and to the Sirr al-Asrār. See Forster 2006,18, and 22; Manzalaoui 1974, 175-184; Grignaschi 1976, 15-23; Walzer 1985, 11-12; . The treatise, which starts on fol. $3 r$ with a repetition of the name of al-Fārābī adds one name attested elsewhere in his biographies - to his genealogy (...ibn Ṭarkhān ibn Awzalagh...).

24 Bayhaqī's Tatimmat Șiwān al-ḥikma was edited by Shafī' 1935, by Kurd 'Alī 1946 and by R. 'Ajam 1994; partial transl. by Meyerhof 1948, 122-217. The Fārābī entry is number 17 in Bayhaqi's collection of biographies. Kurd 'Alī's edition, based on a different manuscript than 'Ajam, is lacking the reference to the "commentary on Zeno and on the Greek Sage” (41 'Ajam). 'Ajam's text (which reflects the 
before his departure to Egypt and Syria, since Bayhaqī states that not all of his works were available in Khorasan. In the introductory lines of the Epistle, Fārābī states that he decided to comment on the epistles of "Zeno the Ancient" or "the Great Zeno" (two valid translations for Zaynūn al-kabïr), a disciple of "Aristotle the Greek Sage (al-Shaykh al-Yūnānì)," epistles that were in circulation among the Christians. ${ }^{25}$ That Fārābī studied with some important transmitters of the Syriac Aristotelian tradition in Baghdad is a well-established fact and this reference to his Christian contemporaries should be accepted as a token of authenticity. However, Aristotle wrote refutations of Zeno's paradoxes and the chronological inversion between the two is almost certainly the result of the former's prestige in ninth-century Baghdad.

In comparison to the text edited in Hyderabad, the London text seems to be abbreviated. The Zeno commentary makes use of philosophical terminology, in particular of the concept of the Necessary Being (al-wājib al-wujūd). It lays out the emanation of the ten spheres and the degrees of reality, including the intelligibles and the sublunar world, in a way which lines up with Fārābī's presentation in the Political Regime (alSiyāsa al-madaniyya) but differs slightly from the one laid out in his most famous work, The Opinions of the People of the Virtuous City (Mabādi' ārā' ahl al-madina al-fādilā), to the effect that the Originator remains "beyond being" in a more radical way. The Virtuous City is considered to be of a later date. ${ }^{26}$ The tonality of the Commentary on Zeno's Epistle, its vocabulary and themes (God's existence, its unicity, its attributes, the emanation of the intellects and that of the sublunar world, prophecy and the religious law...) echoes both the Pseudo-Aristotelian Theology and Pseudo-Ammonius' Opinions of the Philosophers, two works widely quoted by the early Ismaili missionaries at a time when Fārābī was still residing in the eastern Abbasid empire. This type of literature, where a monotheist and creationist inflexion was given to the ideas of

13th-century rendering of the Tatimmat by the anonymous author of the Muntakhab Siwan al-hikma) agrees with the reading of the Hyderabad edition (with additional "and"). Hans Daiber has discovered a number of new manuscripts of Fārābī’s Commentary on Zeno's Epistle, the study of which will help decide for the better reading, see Daiber 2009), $\mathrm{nn}^{\circ}$ 597; 617; 647; 897.

25 The "Greek Sage" usually refers to Plotinus, whose Enneads are often quoted in Arabic under the authority of a "Greek Sage (al-shaykh al-yūnānī)", although Porphyry, his disciple and the ultimate editor of the Plotinian writings, is known to have been nicknamed "the old man of Tyre" by Themistius, see Rosenthal 1974, 437-46; Aouad 1989; Zimmermann 1986, 110-240. The formulation of the London manuscript differs from the one we read in the Hyderabad edition (see supra fn. 22) of Fārābī's Commentary on Zeno's Epistle, p. 3 ("to comment on the epistles of Zeno the Ancient/the Great Zeno and on those of the Greek Sage...”).

26 A summary of the Opinions of the Inhabitants of the Virtuous City was edited by Walzer in his introduction to his edition and translation of the Virtuous City (Walzer 1985, 20-21, 38-49. Summaries like this allowed booksellers and scholars to offer items they had in stock for copy to distant customers or colleagues. According to Grignaschi 1976, 64, Fārābī completed chapter 28 of his Virtuous City in 331/942-943 - that is to say within a year after the completion of the model from which the London manuscript was copied, considering that the quality of the paper is a strong indication that the manuscript we possess today is a copy of an older original. 
ancient Greek philosophers, seems to have played a certain role in the diffusion of Islam in regions that were not yet entirely Islamized. ${ }^{27}$

If the attribution of the commentary to Zeno's epistle to al-Fārābī remains to be demonstrated, his influence on the Fatimid Ismaili theologians and their Druze rivals needs to be further investigated. The Druze epistles are believed to have been written during the Fatimid caliphate in Egypt and Syria, two regions in which al-Fārābì had stayed during the last years of his life, more than seventy years before the supposed date of their composition. Al-Fārābī might, in turn, have been influenced during his youth in Khorasan by the intellectual activity of the Ismaili propagandists, as has been suggested by Hans Daiber. ${ }^{28}$ The Sirr al-Asrār itself could well have been in circulation among the Shiite Zaydites and their Ismaili rivals in northern Khorasan and Tabaristan. ${ }^{29}$ Concurrently, or shortly after the Druze epistles started to be put in circulation, the Ismaili theologian Ḥamīd al-Dīn al-Kirmānī was adapting Fārābī's theory of the ten intellects (which appears in a summarized way in the Comm. in Zeno) into the Ismaili doctrine. ${ }^{30}$ The Brethren of Purity, whose relation with the Sirr al-Asrār and with Fārābī has long been noticed but remains to be studied, were among the Ismaili predecessors of Kirmānī who perused al-Fārābī's writings. ${ }^{31}$ Parallels between the portrait of the ideal vizier according to Book IV of the Sirr al-Asrār (in both the Short and the Long Forms) and the portrait of the "imam-philosopher" in Fārābì, which in turn closely resembles the one we find in the epistle of the Brethren of Purity, has puzzled researchers since the very beginning of the Sirr al-Asrār studies. ${ }^{32}$

If the London manuscript or its archetype was once in the collection of Druze scholars, the subjects dealt with in its different epistles would have been familiar topics. The themes represented in the London manuscript would have been of interest

27 This was certainly the case of most regions administered by the Samanids, Ziyarids, Buyids, and Saffarids at the time al-Fārābī was alive.

28 Daiber 1991, 143-150; on a similar line but adding the Brethren to the picture and pointing to Fārābī as possibly more than just influenced by Ismailism, Steigerwald 1999, 455-476.

29 Manzalaoui 1974, 152-153, nn²5-26, points at two manuscripts (= Badawī’s edition w and g) as possibly being dedicated to a Zaydi imam of Yemen. Several manuscripts (both Short and Long Form) stem from Yemen (see Manzalaoui, $n^{\circ}$ 5, 25, 26), however, the prince mentioned in the dedication of $n^{\circ} 25$ is not a "Zaydi imam" but the son of a famous 16th c. Yemeni Tahirid vizier of the king 'Āmir 'Abd al-Wahhāb [r. 1489-1517], whose court was based in Ibb. In the Sprenger manuscript preserved in Berlin (Sprenger 943, 16th c., on which see infra part IV.3), the copyist gives his name as Ibrāhīm b. Yaḥyā b. Qāsim b. Aḥmad b. al-Mahdī b. Yaḥyā b. Manșūr b. Yaḥyā b. Manșūr b. al-Mufaḍ̣al al-Hādī, which seems likely to be a Yemenite Zaydite name.

30 De Smet 1995, 272-284.

31 Ahmad Triki (al-Turaykī), author of a thesis on the Brethren of Purity, produced an edition of the Sirr al-asrār, in which he claimed that the Epistles of the Brethren and the Sirr share a single author. Cf. Turaykī 1983 ( $2^{\text {nd }}$ ed.).

32 These parallels were first listed by Verdenius 1917, 28-39, using Dieterici's partial translation of the Brethren of Purity. See further Manzalaoui 1974, 175-184 and 196-198 adding further parallels with al-Fārābī and the text and translation in Walzer 1985, 230-241, 246-249. 
to any philosophically inclined mind in the tenth-century, and the insertion of al-Kisā'î's lexicographical treatise on common mistakes further places the collection within a milieu of Arabized Persians. This would apply to Samanid Mashhad, as much as to the intellectual circles in which al-Fārābī evolved and to the use by the copyist "Muhammad ibn 'Alī ibn Durustawayh al-Isbāhānī” of the Arabic pronunciation of Isfahan's name rather than the Persian one ("al-Isfāhānī”). As to the yet unpublished Arabic translation of the Pseudo-Hippocratic Letters preserved in the London manuscript, it transmits the Stoic vision of the philosopher as best ruler and should therefore be compared with Fārābī's conceptions of the philosopher-king, alongside the Platonic and (Pseudo-)Aristotelian political treatises available to him. ${ }^{33}$ Finally, most of the treatises preserved in the London manuscript, for which a date or an author is known, were extant before the supposed date of the copy (330/941-2). These elements form a strong indication that the texts preserved, if not the actual artefact we possess, should be considered as 'genuine,' i.e. are the witnesses of a classical transmission. ${ }^{34}$ Further analysis of the Physiognomy text (in the second part of this paper), as preserved in the London manuscript, will help us establish this point.

\section{The title of the Physiognomy chapter in the London manuscript}

As was already noted by Manzalaoui, the London Physiognomy provides in its first section (see infra, Table 1, for the text and translation of the full chapter) the title of a book from which it would constitute an excerpt. Furthermore, the introductory lines of the London text allude to the position of the Physiognomy chapter within a wider "Aristotelian" treatise. ${ }^{35}$

Epistle on Physiognomy composed by Aristotle for Alexander. Aristotle the philosopher said at the end of his Book of Rules [lit. Book of the Law], which he composed for Alexander... (Risāla fi

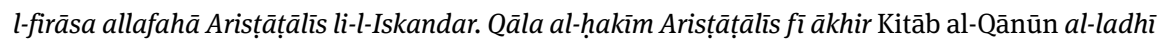
allafahu li-l-Iskandar...). [MS London, Or. 12070, fol. 39v]

This title points to the treatise as having been extracted from a larger collection circulating under the title Kitāb al-Qānūn. Trying to make sense of this title, with no

33 Cottrell 2016, 136, n. 22 and the edition of the text in Cottrell, The Pseudo-Hippocratic Letters in Arabic, forthcoming.

34 Grignaschi, who had been informed by a British Museum curator that the London manuscript was raising suspicions, thought that the texts preserved therein were too rare to accept the idea of a simple forgery, cf. Grignaschi 1976, 14.

35 Manzalaoui 1974, 156. Cf. Grignaschi 1976, 14; Forster 2006, 15. 
additional information on a context or other contents, is no easy task. Moreover, qānūn is a loanword in Arabic, and it inherited the polysemy it had in Greek. Arabic qānūn is

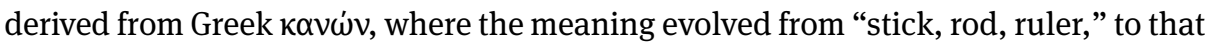
of "list, table, chart," and consequently "rule, law." It is unclear whether it entered Arabic directly from Greek or via Syriac, where the Greek loanword is used for both grammar and ecclesiastical "rules" and "precepts," but also for "lists” or "tables," as in Greek. Further meanings derived from the preceding ones are attested in Syriac, such as "hymns" and "penalties." 36 The polysemy of qānūn makes it impossible to give an exact translation, even more so when the reference is made to a supposedly lost book. The comparison of the Physiognomy chapter of the London manuscript with the versions we have in the Short and the Long Forms of the Sirr al-Asrār led Grignaschi to consider the Qānūn as an ancestor of the versions we possess today. ${ }^{37}$ Anticipating the argumentation which will follow here and in the rest of this paper, we will assume that the London Physiognomy was once part of a text identical or partly similar to the Sirr, and we suggest rendering the title Kitāb al-Qānūn as "The Book of Rules." This translation highlights the role of "rules" or "principles" (of organization of the government and the army, of astrology, physiognomy, hygiene, diets, remedies, magical calculations or the use of talismans...) in the Sirr al-Asrār.

The possibility that the Sirr al-Asrār or parts of it was known as the Qānūn (at least by the copyist of the London manuscript) is made evident by a reference to a qānūn in the introduction of the Sirr, where "Aristotle" states:

\footnotetext{
"I wished to make for you [a set of] rules ( $q \bar{a} n u \bar{n}$ ) that you will use to ponder all your requirements, in replacement of me and as a substitute advising you in the totality of your affairs (raghibtu an aj'ala laka qānūnan taj'aluhu li-jamī ma'āribika mīzānan tuqīmuhu maqāmī fa-yanūbu fī jamī umūrika manābì)".38
}

Deducing the title from the first lines of the text would again support the supposed date of the original from which the London manuscript was copied. But it also seems

36 Liddell and Scott's Greek-English Lexicon, Oxford 1940, s.v. kavúv; Lampe, A Patristic Greek Lexicon, Oxford 1969, s.v. kavẃv; Payne-Smith, Thesaurus Syriacus, Oxford 1879, vol. 2, col. 3660-3661. The early history of the word is summarized by Gorak 1991, 9-31.

37 Grignaschi 1976, 35, 39-47.

38 Pseudo-Aristotle, Sirr al-Asrār, 70 (ed. Badawī), already noted by Manzalaoui 1974, 158. The text of the Short Form, as in MS Leiden, Or. 749, fol. 78r, differs slightly but already has the reference to the qānūn: “...to set for you [a set of] rules you can use for all your decisions... (fì an uqīma laka qānūnan taj'aluhu li-jamī tadābirika)". As a rule, the Leiden Short Form reflects a poorer command of written Arabic than the Long Form versions. This is certainly one of the reasons why the text underwent several revisions. The use of $q \bar{a} \bar{n} \bar{n} n$ here, with Aristotle telling Alexander that he composed the $q \bar{a} n u \bar{n}$ for him so that he can carry it in place of his aging master could be a pun, playing on a double-entendre of Greek кavív. The author of these lines may have had in mind Aristotle's Nicomachean Ethics (III.iv.5), where we find that "the good man ... is the standard and measure (kanôn kai metron) of the noble and pleasant” (transl. Rackham in the Loeb collection, 142 (Gr.)/143(tr.), quoted by Gorak 1991, 17-18). 
possible to say that the semantic value given to the word qānūn corresponds with a date towards the early ninth-century. The Greek loanword seems to have been used with the same sense it carries in Avicenna's Canon of Medicine (al-Qānūn fì al-țibb), written less than a century after the purported date of the London manuscript and where the title is defined in the first lines of the medical encyclopedia as "the exposition of the general and particular principles [using the plural qawānīn] of medicine." ${ }^{39}$ Before Avicenna's Canon of Medicine, qānūn appears mainly in Arabic titles referring to astronomical tables. The most famous of these tables were Ptolemy's Handy-Tables, which circulated in Arabic under different titles but were commonly referred to as Ptolemy's Qānūn, i.e. his astronomical tables. The success of Avicenna's Canon led to the gradual abandonment of this early use of the term. ${ }^{40}$

Considering the full contents of the Sirr al-Asrār, it would be tempting to see in the indication given by the London manuscript a trace of the existence of a corpus of Pseudo-Aristotelian treatises once gathered as his "Canon." After all, a Physiognomy ascribed to Aristotle was translated into Arabic. ${ }^{41}$ But in order to verify this hypothesis, other attestations of the Sirr under alternative titles would have to be identified, which the current state of research in the field of Arabic manuscripts and the very low number of scientifically published material does not allow. Looking for other titles under which the Sirr al-Asrār has been in circulation, we find in the Chester Beatty manuscript (Arabic 4183), copied in 829/1425-6 and studied by Gätje and Daiber, the title Pieces of Advice for Alexander (Nașā’ih Iskandar). However, we would expect to find Nașāih al-Iskandar in proper Arabic so that the title of the Dublin manuscript should be considered as somehow Persianized, and although the

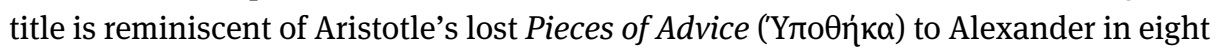
books, no conclusion can be reached. ${ }^{42}$ Additionally, we should mention a note by the

39 We have verified the Leiden manuscript (MS Leiden, Or. 63, 13th c.) of Book I of the Qanūn as well as the English translation published in India, Al-Shaikh al-Ra'is Abu Ali Al-Husain Bin 'Abdullah Bin Sina [i.e. Avicenna] 1982, 31.

40 The polysemy of $q \bar{a} n u \bar{n}$ seems to have led it to be superseded by zìj, a word of Indian origin, commonly used in both Arabic and Persian. Al-Bīrūni's astronomical tables for Mas'ūd of Ghazna, the Qānūn al-Mas'ū ūi, figures as an exception. Ibn al-Nadīm, a Baghdadian bookseller who wrote a catalogue of all the books known to him by the end of the tenth century, mentions only one book under the title of Qānūn, namely a treatise on harmonics ascribed to Euclides. Cf. Ibn al-Nadīm, Fihrist, 206 (ed. A.F. Sayyid)/326 (ed. Tajaddod) and GAS V, 120; 400 (Euclides) and VI, p. 102 (Ptolemy).

41 Edition and Italian translation of the Arabic text by Ghersetti 1999. Edition of the Greek text and English translation by Swain in Swain 2007, 637-661.

42 Gätje and Daiber 1965, 71-78. The Dublin Chester Beatty manuscript is a representative of the Short Form of the Sirr (in eight books), which Manzalaoui considers older than the Long Form and to which we will turn in the next section. Needless to say, such a title might have been on the mind of the forger of a PseudoAristotelian collection (if such a collection indeed existed prior to the compilation of the Sirr al-Asrär). The Pieces of Advice are mentioned in the anonymous catalogue of Aristotle's works (Anonymus Menagii) but Moraux sees it as apocryphal, cf. Moraux 1951, 258-259. The Chester Beatty is listed and briefly described by Manzalaoui 1974, 150; for a wider presentation, see the tables of contents in Forster 2006, 24-29. 
thirteenth-century philosopher Shams al-Dīn al-Shahrazūrī (d. after 1304) where we read that Ibn al-Bitrīq had translated Aristotle's Book of the Politics of the Kings (Kitāb Siyāsāt al-Mulūk) for al-Ma'mūn..$^{43}$ More obscure still is the reference by Manzalaoui to the title Book of the Crown (Kitāb al-Iklīl) under which Hajji Khalifa seems to refer to the Sirr al-Asrār. The title appears in the list of Abū Bakr al-Rāzì's work by al-Bīrūnī, in the section on medical books, as "ascribed to Rāzī," but unfortunately we do not know anything about its contents.

Another title was noticed by Steele in the parallel excerpt he discovered in the universal history of the Christian Egyptian historian Ibn al-'Amīd al-Makin (1205-1273). Al-Makin's work is only partially edited but a number of manuscripts of its (original) Arabic version (extant in two recensions) have been known for centuries. Unfortunately, Steele and Manzalaoui relied on Wallis Budge's English translation of an Ethiopic translation of the Arabic, so that the precise wording of the title in Arabic remained unknown to them and to their readers. What they read in Budge's translation gave them the impression that the title under which al-Makin was providing a short description of the contents of the Sirr could initially be seen as somehow close to a Book of Law/Rules/Principles (i.e. "qānūn") as found in the London manuscript:

\begin{abstract}
"Now there are some who say that Aristotle the sage, the teacher of Alexander, taught the ten sciences of the earth [i.e. universal sciences] and established them, and that he composed many treatises on the healing of the body besides other well-known books. And he compiled for Alexander a work, which we have mentioned in a previous place, and entitled it 'The Book of the Knowledge of the Laws of Destiny,' and in it the science of talismans and the art of astrology, and he drew therein magical figures which were to be used for frightening and terrifying men and he further gave instructions...". ${ }^{4}$
\end{abstract}

After verifying the Arabic text of al-Makin, we can ascertain that the Ethiopic rendering of the title was misleading, and that the Egyptian historian certainly knew the Sirr al-Asrār, which is referred to as "Book of Politics in the Organisation of the Government (Kitāb al-Siyāsa fì tadbīr al-riyāsa)," a title which appears at the beginning of the Sirr (and is repeated at the end of the book in a slightly different form). ${ }^{45}$ This

43 al-Shahrazūrì 1976, 197, 1l. 1-6 (this gloss appears solely in the Short Recension of the Nuzhat). If the lost archetype of the Sirr al-Asrār (as presupposed by Grignaschi and Manzalaoui) could be identified with this work, Grignaschi's hypothesis of the existence of a lost Kitāb al-Siyāsa among the ancestors of the Sirr would find an unexpected confirmation. The paragraph quoted makes a number of references to the Sirr al-Asrar's contents and could confirm Ibn al-Bitriq's authority on the Ur-Sirr. 44 Steele, loc. cit., xxiii, quoting Wallis Budge 1896, II, 382. Cf. Manzalaoui 1974, 244. Al-Makīn further summarizes the "Circle" or "Octagon" of Justice (cf. Steele 1920, lii-liii) although he could have read it in a number of authors such as Ibn Juljul, al-Mubashshir ibn Fātik, Ibn Abī Ușaybi 'a, etc. Steele’s reference to the Octagon as part of Hiunayn's Aphorisms of philosophers and physicians (loc. cit., lii) is erroneous. It corresponds in Ibn Abī Ușaybi a's text to a quotation of Ibn Fātik, following an excerpt from Hiunayn (cf. vol. I, 66-67 of the Müller edition).

45 Al-Makin, al-Majmü' al-Mubarak, MS Paris, BNF, Ar. 294, fol. 129v. The title and a shorter description of the contents are repeated on fol. 136r before a summary of the Octagon of Justice (fol. 136v), to 
title was also known to Ibn Juljul (944-994), an Andalusian court physician in whose History of Physicians (composed in 975) ${ }^{46}$ we find the first reference to the title Sirr al-Asrār known to us, in addition to a number of quotations said to be copied from "the Kitāb al-Siyāsa fì tadbīr al-riyāsa known as the Sirr al-Asrār."

Commenting on the citation of al-Makin, Steele remarked that Roger Bacon used the title "Book of the Ten Sciences (Liber Decem Scienciarum)" and believed Bacon might have been under the influence of the ten-book version of the Sirr al-Asrār (i.e. Steele's "Eastern Version" and Manzalaoui's “Long Form”). ${ }^{48}$ But the ten chapters of the Long Form do not show any attempt to present a division of the text in ten sciences or thematics..$^{49}$ Beyond that, the reference comes somewhat earlier than the description of the Sirr's contents. If the Sirr al-Asrār does have a reference to the quadrivium (p. 116 Badawī, where we read that "music is one of the four sciences which are the pillars of the world") shortly before the chapter on physiognomy in Badawì's edition, no reference to a curriculum of ten sciences can be found in the book. However, such a reference appears in the widely read Aphorisms of the Philosophers (Ādāb al-falāsifa) by Ḥunayn ibn Ishāq, where a curriculum of ten sciences is ascribed to Aristotle. Hugo Bizzari discovered that some of the versions available in medieval al-Andalus had Hunayn's work together with the Sirr al-Asrār, possibly because of some parallels in the Alexander material. ${ }^{50} \mathrm{Be}$ that as it may, the ten sciences of the curriculum have little to do with the structure of the ten-book version of the Sirr and Steele's hypothesis can be safely abandoned.

Turning finally to the purported author of this Qānūn, and looking at the Greek

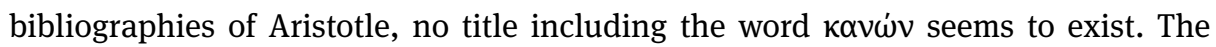

which we will return at the end of this paper. For the titles, different at the beginning and the end of the text, see Pseudo-Aristotle, Sirr al-Asrār, 67 Badawī: Kitāb al-Siyāsa fī tadbīr al-riyāsa al ma- 'rūf biSirr al-Asrār, and loc. cit. 171: Kitāb Sirr al-Asrār li-ta'sīs al-siyāsa wa tartīb al-riyāsa which translates as Book of the 'Highest Secret' [or 'Secret of Secrets'] for the Establishment of Politics and the System of Government.

46 Grignaschi $(1976,12)$ mentions the date after Ibn al-'Abbār (d. 1260).

47 Ibn Juljul, Țabaqāt al-ațibbā' wa-l-ḥukamā', ed. Sayyid 1955, 26. The Kitāb al-Siyāsa fī tadbīr al-riyāsa (i.e. the Sirr al-Asrār) should not be confused with the related treatise titled Kitāb al-Siyāsa al-Ammiyya, which constitutes "Letter VIII" of the Pseudo-Aristotelian Epistolary Novel, a purported correpondance between Aristotle, Philip of Macedonia and Alexander the Great culminating in a famous Aristotelian apocryph, the De Mundo. Grignaschi suggested that the Sirr al-Asrār was an 11th-c. rearrangement of the Siyasa al-'Ammiyya ultimately based on a lost Book of Politics (Kitāb al-Siyāsa) (Grignaschi 1967, 212).

48 Steele 1920, xxiii, referring to his edition of Roger Bacon's commentary to the Sirr (loc. cit., 25, 172). Manzalaoui 1974, 244, on al-Makin's references to the Sirr.

49 For a short description of the ten books see Anawati 1955, 60-70 (often based on Steele 1920, xxxvii-lxiii).

50 Ḥunayn ibn Ishāâ, Ādāb al-falāsifa, 55 (ed. Badawi); Ḥunayn ibn Ishāq, Libro de los Buenos Proverbios, 62 (ed. Sturm 1970). For versions where the Ādāb al-falāsifa and the Sirr are found attached, see Bizzarri 2010, 36-54; cf. Salvador Martínez 2010, 69. 
closest in meaning would be the lost Aristotle's Laws (Nó $\mu \omega v$ ) in four books (Diogenes Laertius, Lives and Opinions of the Philosophers, 5.26.29) but little can be said of this lost work. ${ }^{51}$ Nor do we find in the Arabic bibliographies of Aristotle any item under this title apart from al-Fārābī's description of each one of the eight books of Aristotle's Organon as a set of 'rules' or 'principles' (qawānīn....). ${ }^{52}$ As to the expression 'Aristotelian canon,' which naturally comes to mind when inquiring into the existence of a Pseudo-Aristotelian $q \bar{a} n \bar{u} n$, it seems to appear at a rather late date, under the influence of Christian scholasticism. In Christian writings and mainly after Eusebius

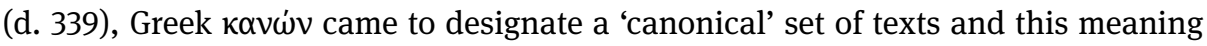
has remained prevalent in Latin and in the languages derived from it. ${ }^{53}$ However, if Ibn al-Bitrīq (fl. first half of the ninth-century) ${ }^{54}$ is indeed the actual author of some of the translated material compiled in the Sirr, as will be suggested in the conclusion of this paper, and if indeed he was the one to designate the collection as a qānūnsomething impossible to prove unless new manuscripts are discovered - he might have used the word with its late and largely Christian semantic value of "authoritative collection of texts." Such a title would certainly fit into the compendial character of the scientific and pseudo-scientific tractates aggregated in those parts of the Sirr that do not deal with politics. ${ }^{55}$

\section{The position of the Physiognomy in the different versions of the Sirr al-Asrār}

According to the few lines introducing the Physiognomy in the London manuscript (Table 1, section [A.] infra), the chapter was located somewhere near the end of the Qānūn. ${ }^{56}$ This corresponds to the position of the Physiognomy chapter in the Short Form $(=\mathrm{SF})$ of the Sirr al-Asrār rather than to its position in the Long Form (= LF). ${ }^{57}$

51 Moraux 1951, 130-131, esp. 130, n. 44, suggests correcting the reading of the title in Diogenes Laertius with the help of the anonymous catalogue of Aristotle's works (Anonymus Menagii) and identifying the Laws with a treatise on Greek and Barbarian 'Customs (Nó $\mu \mu \alpha)$ ', known from a number of quotations.

52 The Fārābī excerpt appears in Ibn Abī Ușaybi'a's bibliography of Aristotle ('Uyūn al-anbā fì tabaqāt al-ațibbä', vol. I, 58-59, ed. Müller).

53 Ulrich 2002, 22-28.

54 On him, see Forster 2006, 52-54.

55 According to Ibn Abī Ușaybi'a ('Uyūn al-anbä’, I, 205 Müller), Ibn al-Biṭrīq was a weak translator because of his western background (lāțīnī).

56 Grignaschi, "Les Métamorphoses," 44-46, developed a number of hypotheses about the relation of the Qānūn and the two versions of the Sirr we possess today, but as will be developed in this section and in the third part of this paper, the evidence given by Grignaschi appears to be weak in a number of cases. 57 In the following footnotes we will often use Manzalaoui reference system: SF for Short Form, SF7 for the seven-book form, SF8 for the eight-book form, LF for Long Form (usually in ten books). 
In the Berlin Sprenger manuscript (an SF7), the table of contents decribes the last chapter of the book on the "occult sciences (ulüm khașsiyya)" as including the secrets of talismans (țilsamāt), theurgy (istimālat al-nufūs), the properties of stones, plants and animals, "and [some] wonderous issues among the secrets of medicine (wa-nukat gharība min asrār al-țibb)" seemingly leaving aside onomancy and physiognomy, unless the former was considered to be part of theurgy and the latter part of the secrets of medicine. The same reference to the "wonderous issues among the secrets of medicine" is repeated in the first lines of the section on Hygiene in the Paris SF8 (Paris, BNF 2421) that is to say after the Onomancy and Physiognomy, which precede in this witness the section on Hygiene, the Lapidary and the section on Talismans. The Leiden manuscript (an SF8), usually considered to be one of the best preserved representatives of the Short Form, ${ }^{58}$ displays the Physiognomy in its eighth and last book. ${ }^{59}$ The floating position of the Physiognomy, from one manuscript to the other, points to the section as having been added at some point in the transmission, but its inclusion in all the SF7 and SF8 witnesses - as well as in the Long Form - implies that the insertion happened at an early stage. Yet another indication that a position near the end of the text rather than at the end of Book II (as in the Long Form) must have been the original position is the place occupied by the Physiognomy chapter in the undated, but medieval, Hebrew and Spanish versions, as well as in Roger Bacon's commentary. ${ }^{60}$ In contrast, the position of the Physiognomy at the end of Book II in most of the Long Form manuscripts that are available to us gives the impression of an interruption in the themes of Books II and III. ${ }^{61}$

Manzalaoui, “The Pseudo-Aristotelian,” 229, suspected Badawi's edition - in the absence of any clear indication by Badawi - to be based on the Long Form manuscript MS Cambridge Arabic 899 as a primary witness; see Sirr-Badawī, introd. 42 for its date and the anteriority of the Berlin 5604 among the manuscripts he used. The English translation realised for Steele by Ali and Fulton is based on a LF Gotha manuscript (with variants from other SF and LF manuscripts given in the notes), in Steele, Secretum Secretorum, 176-266.

58 On the superiority of the Leiden manuscript among the SF8 versions, cf. Grignaschi 1982, 7. The order of the books in the Short Form would also be closer to the one it had in the lost archetype of SF and LF (loc. cit., 6). Grignaschi 1976, 65) is erroneous in believing the Leiden manuscript can be dated of the 15th century. It belongs rather to the 17th century and was probably copied at the request of Levinus Warner (1616-1665), judging from the paper and its watermarks. For the position of the section in the different witnesses of the Short Form, see the comparison of the manuscripts in Forster 2006, 25. A description of the table of contents in a sample of Short Form manuscripts is given by Grignaschi 1976, 97-101.

59 The Leiden manuscript has a binding mistake which resulted in part of the Physiognomy section appearing in Book IV (cf. Forster 2006, 25, n. 111). A better understanding of the stemma would help us to know if this error was caused by the model used by the Leiden manuscripty's scribe and/or if it resulted in the displacement of the chapter in later copies.

60 Forster 2006, 25. Cf. Gaster 1908, 111-162, where the Physiognomy appears at 148-152. On the Hebrew version(s), see the important remarks of Spitzer 1982, 34-54 esp. 37-45 and Grignaschi 1982, 20. For the medieval Spanish version, see the edition by Kasten 1957, 62-66.

61 The thematic continuity between Book II and Book III is interrupted by a series of unrelated medical and pseudo-scientific sections, as pointed out already by Steele 1920, xiv. Once the unrelated 
The inclusion of the Physiognomy section at the end of Book II gives it, nevertheless, a more prominent place than the one it received in the Short Form. Possibly, the person who added to Book II a number of tracts missing in the Short Form used the opportunity made available by his new edition to give physiognomy - a "science" supposedly praised in a saying of the prophet Muhammad ${ }^{62}$ - a more prominent place, removing it simultaneously from the chapter on occult sciences. ${ }^{63}$ The insertion of the teachings on physiognomy at the end of Book II also moves the reference to this pseudo-science closer to both the portrait of the ideal sovereign (in Book II, 77-78 Sirr-Badawī) and to that of the ideal vizier (in Book IV, 138-139 Sirr-Badawī). These portraits, without focusing on the bodily characteristics, make reference to some of the features that will be found in the Physignomy, as will be shown in the third part of this paper. Finally, a last possible indication that the Long Form rearranged earlier materials is found in the table of contents in the introduction of the text, where the topics of Book II are described as the etiquette of the sovereign, his behaviour and his habits. ${ }^{64}$ The theme of the habits which the king should observe may have attracted the long medical developments resulting in the insertion of medical sections (diet, remedies, sleep, cupping and bidding, bath, etc.).

\section{The Onomancy chapter and its relation to the Physiognomy}

In most of the Short Form manuscripts, the Physiognomy usually comes directly before or after the Onomancy (or onomatomancy). Onomancy is a magical method based on numerical computations using the values given to letters. In Greek, Hebrew and Arabic (among others languages), numbers were written at some stage using

material is removed, Manzalaoui finds Platonic overtones in Book II and III, cf. Manzalaoui 1974, 208-209. The importance given to justice in the Sirr al-Asrār, more specifically in Book III, echoes Plato's Republic, Book IV, 444c-444e where the analogy is made between justice, health and virtue. 62 The wording of this saying, preserved in Bukhari’s collection of prophetic sayings (hadith-s) remains extremly obscure, see Ghaly 2009, 164-165; Fahd 1966, 379; De Smet 2012, 324-325 noticed the Druze interest for the pseudo-science.

63 On the composition of Book II, cf. Steele 1920, xiv. Grignaschi 1976, 51, admits that the original place of the Physiognomy in the (lost) archetype of SF and LF must have been somewhere at the end of the book. A reference to the "priests" (kahana) who practiced the art in the introductory paragraphs (cf. Table 1, section [B.2.]) would legitimate the insertion of the Physiognomy among the occult sciences.

64 As expressed in the title "On the behaviour of the king and his appearance and how he should control his person privately ( $f \grave{i}$ hal al-malik wa-hay'atihi wa-kayfa yajibu an yakūna ma'khadhuhu fi khașșati nafsihi) (Sirr, 77 Badawī). Manzalaoui gives numerous examples in which the Long Form seems based on the Short Form rather than the opposite (Manzalaoui 1974, 224-227; 229-232. Steele 1920, xiii, considered SF as the oldest version. Grignaschi 1976, 34, noticed that the Physiognomy, as part of medicine, is announced in the table of contents of the Short Form versions but is missing from the table of contents of the Long Form. 
the letters of the alphabet, so that each letter had a numerical value. The method explained by Aristotle to Alexander, based on what would today be called modular arithmetic, is said to help determine the name of the victor between two commanders. In the Short Form versions, Onomancy and Physiognomy usually appear in the last chapter or in the one before the last. In the seven-book version (SF7), the last chapter is most often titled "On medicine" while in the eight-book version (SF8), the last chapter is designated as addressing "occult sciences." In the case of the Berlin Sprenger manuscript, which according to Grignaschi preserves the fullest SF7 version and the most ancient readings, ${ }^{65}$ the contents announced for the seventh and last book are spread before and after the title, reduced to "Book VII, on medicine". ${ }^{66}$ These elements could confirm the possibility of an interpolation. In the Long Form, the Onomancy appears separately in the chapter on wars and soldiers, which corresponds to the theme of the treatise better than an insertion in the chapter on medicine. Nevertheless, the close relation of what might otherwise seem like two independent leaflets is betrayed by the common rhetorical admonition introducing both texts: "And as to what you really ought to know, O Alexander...”. But the comparison with the Short Form reveals that this is the result of a stylistic harmonization produced by one of the Sirr revisers. ${ }^{67}$

As was noted long ago, the Onomancy chapter appears to have circulated independently, in both Arabic and Syriac. ${ }^{68}$ Its first attestation in Arabic comes in an astrological treatise ascribed to Abū Ma'shar (ca. 787-886) which incidentally claims Greek influences, the Kitāb al-Muhaqqiq al-Mudaqqiq al-Yūnānī (lit. "The Greek Meticulous Investigator"). ${ }^{69}$ Abu Ma'shar's treatise remains unstudied until this day so

65 Grignaschi 1976, 83 (on the Sprenger Short Form); pp. 99-101 (on the table of contents of some representatives of the Short Form).

66 For the Onomancy and the Physiognomy attached to each other in the witnesses of the Short Form, cf. Forster 2006, 25 and 29. In Badawì's edition of the Long Form, the Physiognomy appears at 116-124, closing Chapter II, while the Onomancy appears at 152-155, closing Chapter IX (on wars and related techniques).

67 Physiognomy: wa-min jumla mā lā ghinā' bika 'an 'ilmihi yā Iskandar... (Sirr-Badawī, 116). Cf. Onomancy: wa-mimmā lā ghinā' bika 'anhu yā Iskandar... (Sirr-Badawī, 152). The introductory lines of both tractates differ in the Short Form. In the onomancy, Aristotle squarely claims divine revelation for his learning of the method: "....and it is among the divine secrets which God entrusted me with... (wa-huwa min al-asrār al-ilāhiyya al-latī awda'anī Allāh iyyahā...)” (MS Berlin, Sprenger 943, 14v). As to Alexander's use of physiognomy, instead of the exhortation found in the Long Form (Sirr-Badawī, 116), Aristotle tells his pupil about the need for the sovereign to evaluate the trustworthiness of people (MS Berlin, Sprenger 943, 16r/MS Dublin, Chester Beatty Ar. 4183, 28r/MS Leiden, Or. 749, 106v). I am extremely grateful to Regula Forster for sharing with me some of her material relevant to the study of the Short Form.

68 Steele 1920, lix-lx; cf. Plessner 1925, col. 917.

69 Abū Ma'shar, ca. 1920?. Pingree 1970, vol. I, 36-37, suggested identifying the Muhaqqiq with Abū Ma'shar's Kitāb al-Mawālìd al-Saghìr and states that the tract on onomancy is commonly ascribed to Pythagoras and to Petosiris in classical works. 
that the attribution is hard to confirm, but nothing really seems to prevent it. Dunlop pointed out the discovery by Paul Tannery of a number of Greek parallels to the tract, one of them explaining the very method which we find exposed systematically in Abū Ma'shar's chapter and in the Sirr's section, while the other versions give a direct application of the method in the form of tables of equivalences between letters and numbers so as to determine more quickly the "value" of a name and its strength against the adversary's name. ${ }^{70}$ Tannery further discovered that a systematic explanation of the method had been described in Hippolytus' Refutation of All Heresies, an early Christian haeresiological compendium in which Greek philosophers were blamed for their supposed dualism or magical beliefs. Tannery's findings proved the antiquity of the material that Hippolytus relied on and helped determine the dates of tracts which circulated among Roman astrologers such as the Letter of Pythagoras to Telauges or an epistle by the magician Petosiris, where similar methods as those used in the Sirr's Onomancy can be found..$^{71}$ Neither the Pseudo-Hippolytus nor Abū Ma'shar ascribes the method to Aristotle, a characteristic which may indicate its early date in contrast to the Sirr and its tendency to ascribe to Aristotle all sorts of scientific tracts. ${ }^{72}$

A later piece of evidence for the circulation of the Onomancy as an independent tract lies in the testimony of Ibn Abì Ușaybi'a, a thirteenth-century physician who had privileged access to some of the main libraries of his time. His mention of a Kitāb al-Ghālib wa-al-maghlūb ("The Victor and the Vanquished") in his bibliography of Aristotle is parallel to the title found in both $\mathrm{Abu} \mathrm{Ma}$ 'shar and the Sirr at the beginning of the treatise. The addition by Ibn Abī Ușaybi 'a of an alternative title (Kitāb al-Yatīm, i.e. "The Book of the Orphan"), unkown in the Sirr tradition, seems to be a definitive proof of an independent diffusion. ${ }^{73}$ Grignaschi - who elsewhere proved he was an outstanding philologist - oddly never identified this Kitāb al-Yatīm with the mean-

70 Dunlop 1959, 148 referring to Tannery 1844, 231-260.

71 Tannery 1844, 234 and 249, explains the various purposes of the Greek tracts as determining the victor in a trial, a fight, a competition, or a concourse. He notes a parallel in the Pseudo-Hippolytus' Philosophumena, where interestingly for future studies of the Sirr al-Asrār and its sources, the onomancy is followed by a section on astrological physiognomy derived from Ptolemy's Tetrabiblos, Book III. See the translation of Legge 1921, 83-87 and 87-92. Ibn al-Bițīq's father seems to have played a part in the translation of the Tetrabiblos, according to Ibn al-Nadìm. Dunlop was not aware that a number of excerpts of the Pseudo-Hippolytus' Refutation found their way into the Arabic Opinions of the Philosophers, ascribed to a certain Ammonius, as was discovered by Rudolph 1989, 23-25.

72 In addition to the witnesses listed by Forster 2006, 13-14, the chapter on onomancy is ascribed to Aristotle in the Syriac Book of Medicine, translated by Wallis Budge 1913, a late compilation of earlier tractates of Syriac and Arabic origin. A chapter titled Hisāb al-ghālib wa al-maghlūb appears in a miscellaneous collection preserved in Leiden (MS Or. 958, fol. 45v-46r, copied in the 16th c. and mainly preserving Iranian authors) where it figures directly after a series of Medical questions (As'ila min $a l-t ̦ i b b)$ taken from an unknown work by Abū Bakr al-Rāzī using the Problemata form, with questions starting with the formula "Why is it that (li-ma șāra)?" (loc. cit., 39r-45v).

73 The onomancy is mentioned by Ibn Abī Ușaybi'a, 'Uyūn al-anbā' fì Ṭabaqāt al-aṭibbā', vol. I, 69 Müller. 
ingless "Kitāb al-Nìm" (Book of Nim ?) he had discovered in an Istanbul manuscript (MS Aya Sofia 2843) of the Sirr and in an Ottoman treatise on politics, where he had found excerpts of a Kitāb al-Siyāsa (i.e. "Book of Politics") which he believed derived from an ancestor of the Sirr al-Asrār. ${ }^{74}$ Another piece of evidence that Grignaschi did not address is the fact that the beginning of the Onomancy in the Istanbul manuscript (MS Aya Sofya 2843), which he reproduces (and translates correctly) in his "Appendice III," states that the "Kitāb al-Siyāsa fĩ Tadbīr al-Riyāsa is completed" implying that what follows (the Onomancy) was considered to be independent material. ${ }^{75}$

Strikingly, both Aristotle and the magician Apollonius of Tyana (known in Arabic as "Balinas") are said in some of their Arabic biographies, or in their own purported works in Arabic, to have been orphans. In a spurious biography known to Hunayn ibn Ishāq sometime around the beginning or the middle of the ninth century, Aristotle was said to have met Plato while the latter was tutoring the son of a Greek king who showed no capacity whatsoever for learning. Aristotle, then a lad at the court and the companion of the king's son, secretly took this opportunity to learn and was finally given the occasion to demonstrate his intelligence, to the point that he became Plato's best student and successor. ${ }^{76}$ As for Balinas, whose largest work in Arabic is the Book of the Secret of Creation (Kitāb Sirr al-Khalīqa), which makes use of a variety of Late Antique Greek and Christian sources, he claims to have been an orphan (yatim) in the first lines of the book. ${ }^{77}$ The Sirr al-Khaliqa was composed during the reign of al-Ma'mūn (r. 813-833), in whose chancellery Ibn al-Bițīq, the purported translator of the Sirr al-Asrār, was practicing his activity. ${ }^{78}$ The Sirr al-Khaliqqa was shown to borrow

74 Grignaschi 1976, 28-29. In Arabic, النيم (al-nïm) are easily confused in a hasty scribal hand (as was already noted by Dunlop 150, n.1 and after him by Peeters 1968, 71). On the Kitāb al-Siyāsa and its relation to the Sirr al-Asrār and to the Kitāb al-Siyāsa al-'Ammiyya, see Grignaschi 1976, 9-12.

75 Grignaschi 1976, 93-95. In the Istanbul Aya Sofia 2843 version (a Long Form) the Onomancy follows a tract on botany. Example (c) in Grignaschi's comparison of three onomancy chapters (loc. cit., 93 and 96-97) is misleading: the Oxford manuscript (an SF7) has no reference to a Book or Calculation of the $\mathrm{Nim}$. It is designated there as "The section on the number deduced (i.e. the denominator) for the victor and the vanquished (al-qawl fi al-'adad al-kharj li-l-ghälib wa-l-maghlüb)," which Grignaschi translates rather vaguely as "Le Discours sur le Calcul. Les deux tableaux (lit. sacoches) du Victorieux et du Vaincu" (loc. cit., 96). His reading should be corrected with the identical title preserved in the Berlin Sprenger manuscript (Berlin, Sprenger 943, fol. 14v): al-qawl fi al-'adad al-makhraj li-l-ghālib wa-l-maghlūb.

76 Ḥunayn ibn Isḥāq, Ādāb al-falāsifa, 51 Badawī. On the possible Alexandrian origins of the story, see Gutas 1986, 30-31.

77 Balīnas al-Ḥakīm 1979, 5. Weisser 1980, 24.

78 Forster 2006, 50-53 and 12, n. 10 pointing to Badawī and Van Ess as accepting Ibn al-Bițrīq's attribution. Plessner also admits Ibn al-Bițrīq's role (Plessner 1925, coll. 912-920). Badawī, al-Ușūl al-Yūnāniyya 33-35, provides details on the identification of the caliph to whom the work was dedicated, namely al-Ma'mūn [r. 813-833]. Al-Ma'mūn's interest in a Persian text known as the Testament of Ardashir, and his own background, (his mother was of Persian extraction), in addition to his long stay in Merv during the years preceding his accession to the caliphate, agree particularly well with the contents of the Sirr al-Asrär. 
large extracts from the Problemata tradition in a similar way as Job of Edessa (d. ca 835) in his Book of Treasures (composed 817), where a number of parallels to the Sirr al-Khaliqa can be found. ${ }^{79}$ The fact that Job of Edessa and Ibn al-Bitrīq were close colleagues at the Abbasid court under al-Ma'mūn points to the fact they almost certainly knew the onomancy of the Sirr or Kitāb al-Yatīm, as did their colleague Abū Ma'shar, but we cannot know for sure if they knew it under the title Book of the Orphan.

With this fragmentary view of a complex textual tradition in mind, we can now turn to the comparison of the text proper. This will help us determine the quality of the text preserved in the London manuscript.

\section{Table 1: Comparison of the London Physiognomy and the Long Form version of the Sirr al-Asrar}

For the comparison of the London Physiognomy with the Physiognomy chapter preserved in the Sirr al-asrār as edited by Badawi in Table 1 the following codification was used: (1) Italic for minor differences that can be explained by common scribal mistakes and rewriting (including paleographic confusion; use of a synonym; modernisation of the vocabulary and minor changes in grammar or syntax). ${ }^{80}$ (2) Bold for differences in the order of the elements (more significant than simple inversions) within a section. (3) Underlined for original elements in one version or the other. Some original elements might be italic and underlined where synonymy or paleographic proximity might have been involved. For the religious formulas, differences have been highlighted as underlined, although they depend very much of the tastes of copyists and might as well have been rendered with italics. A hash mark (\#) is used to indicate a different order for a whole section. A number of rather small additions in the Long Form, in comparison to the London text, have not been reproduced due to the lack of parallel between the two texts and they are represented in our table with parentheses and ellipsis. The full text of LF can nevertheless be found in the table of comparison for LF and Abū Bakr al-Rāzī’s Ṭibb al-Manșūrī in Regula Forster's paper in this volume.

Commenting on Table 1 is not an easy task: Badawì's edition should be considered as yet another "mixed version" of the text, since the late Egyptian scholar used manuscripts of the three main versions of the text (SF7, SF8 and LF) without chosing one as a base text. Nor did he provide a full apparatus indicating the variants, omissions,

79 Montgomery 2013, 307. Weisser 55-68. Moreover, the alchemical Tabula Smaragdina appears in both the Sirr al-Asrār and in the Sirr al-Khaliqa, see Forster 2006, 104.

80 Minor semantic and syntaxic changes are part of scribal work. These are most often based on local tastes or on the lingustic skills of a patron. 
additions and displacing of the elements. The remarks made from the comparison of the London text and the Badawi edition should be verified on the manuscripts supposedly used by Badawī before any conclusions can be drawn. They should be considered as possible leads more than definitive statements. The comparison tends to confirm Manzalaoui's hypothesis that the London Physiognomy is a "mixed version" including elements from both the Short and the Long Forms. ${ }^{81}$

\section{General organisation of the sections}

The London text can be divided into three main parts, leaving aside section [A.]. Which consists of the title and a short description of the source and has been addressed supra in the section "The Title of the Physiognomy chapter" (p. 366). We find after these introductory lines:

(1) an introduction (sections [B.] to [G.]);

(2) the ideal portrait of who Alexander should take as a friend (sections [H.] and [I.]);

(3) the description of the best physical characteristic for each bodily part (sections [J.] to [L.]).

The comparison of Badawi-Sirr and the London text seems to confirm that the Long Form of the Sirr was revised and edited but that the models from which both texts are derived were extremely close, ${ }^{82}$ although a long interpolation (the anecdote about the meeting of Polemon and Hippocrates) and a different organisation of the sections is also attested. Looking specifically to the introduction, sections [B.] to [G.] in the London text are almost identical to the parallel sections found in Badawi-Sirr, although one can detect in the omissions and additions the work of a reviser. This introduction bears the influence of Adamantius' epitome of Polemon in the reference it makes to the role of "divine men" in the discovery of physiognomy, which is said to be close to an "unerring art of prophecy."

The role of a reviser in the conception of the Long Form as compared to the Short Form was already assumed by Manzalaoui, who believed that the Short Form chronologically preceded the Long Form, although both would derive from a common, lost original. ${ }^{84}$ Grignaschi's position differed in that he thought that the Short Form was

81 Manzalaoui 1974, 233.

82 To give but a couple of exemples of paleographic accidents that demonstrate the reliability of the

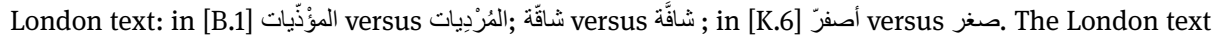
can be used to correct Badawì's edition in a number of instances, such as section [F.] where we find خافياً (“in secret”) in the London manuscript while we read خائف (“frightfully”) in Sirr-Badawī. Suggestions of emendations are mentioned in the footnotes to the texts in Table 1.

83 Cf. Repath 2007, 495-496 (A2). On the absence of a prologue in the Leiden Polemon, see Repath 2007, 488. The Sirr witnesses seem to retain here elements that might have been expurgated in the process of transmission.

84 Manzalaoui 1974, 172-175, 179, 183. 


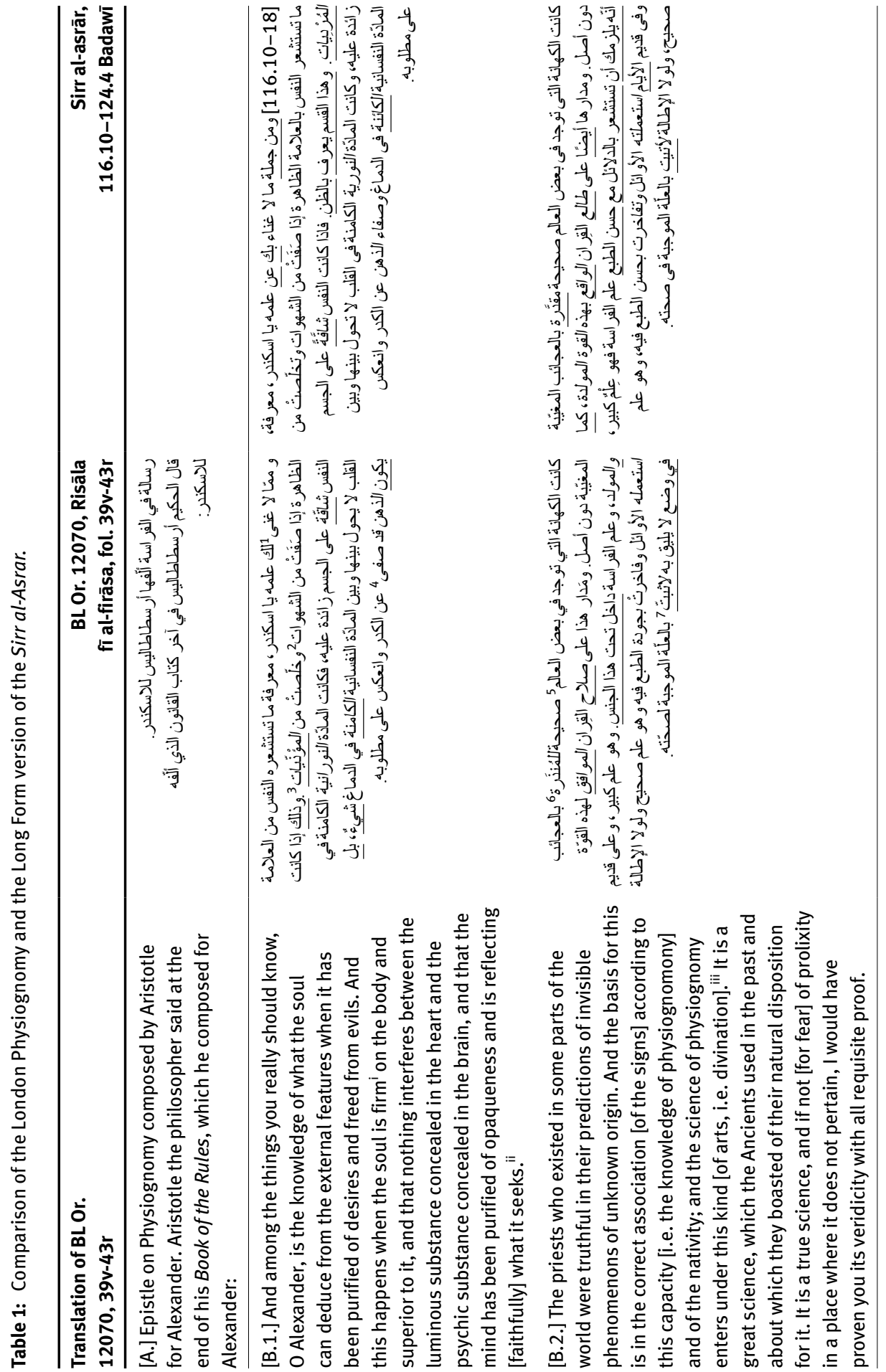




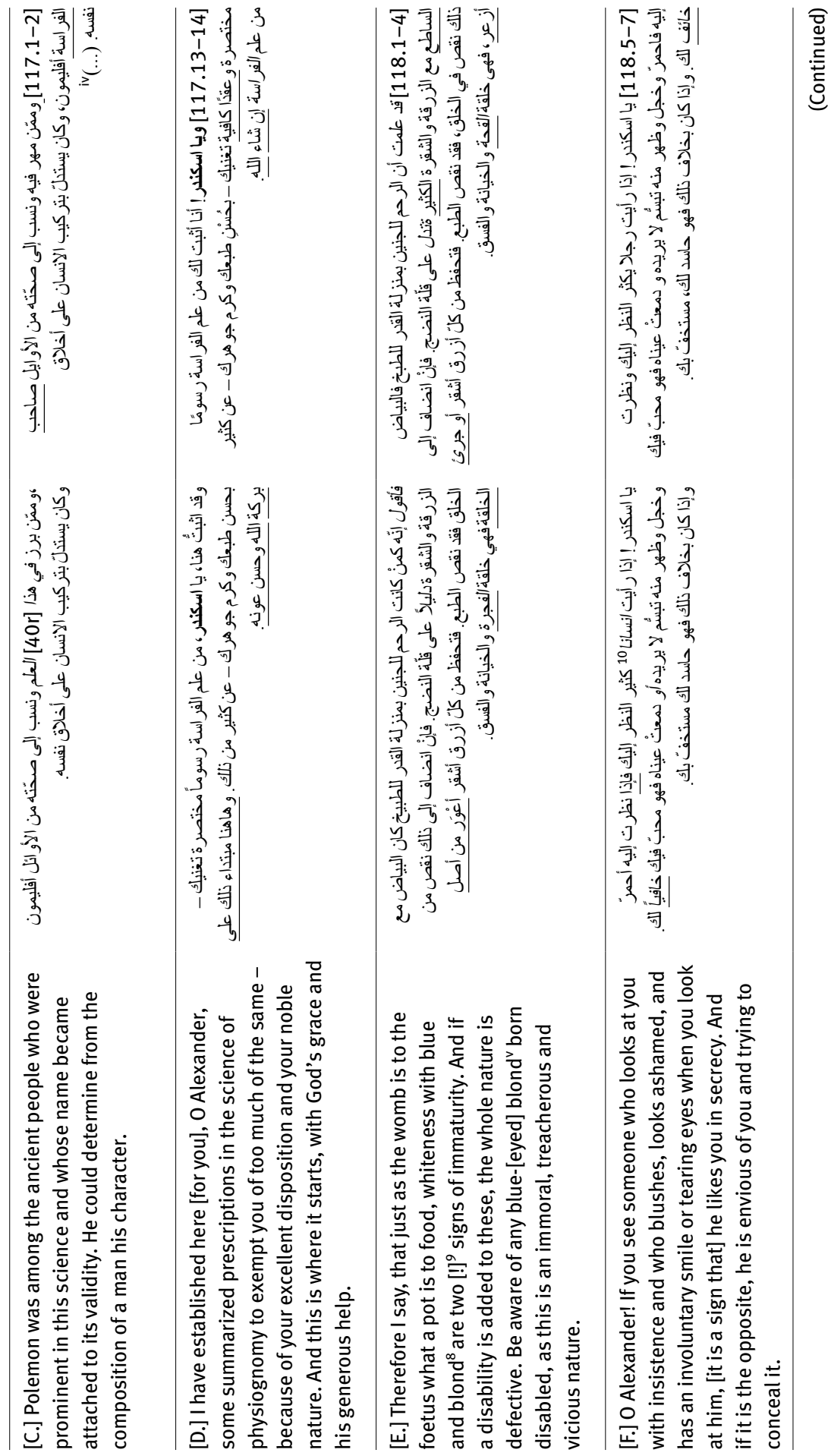




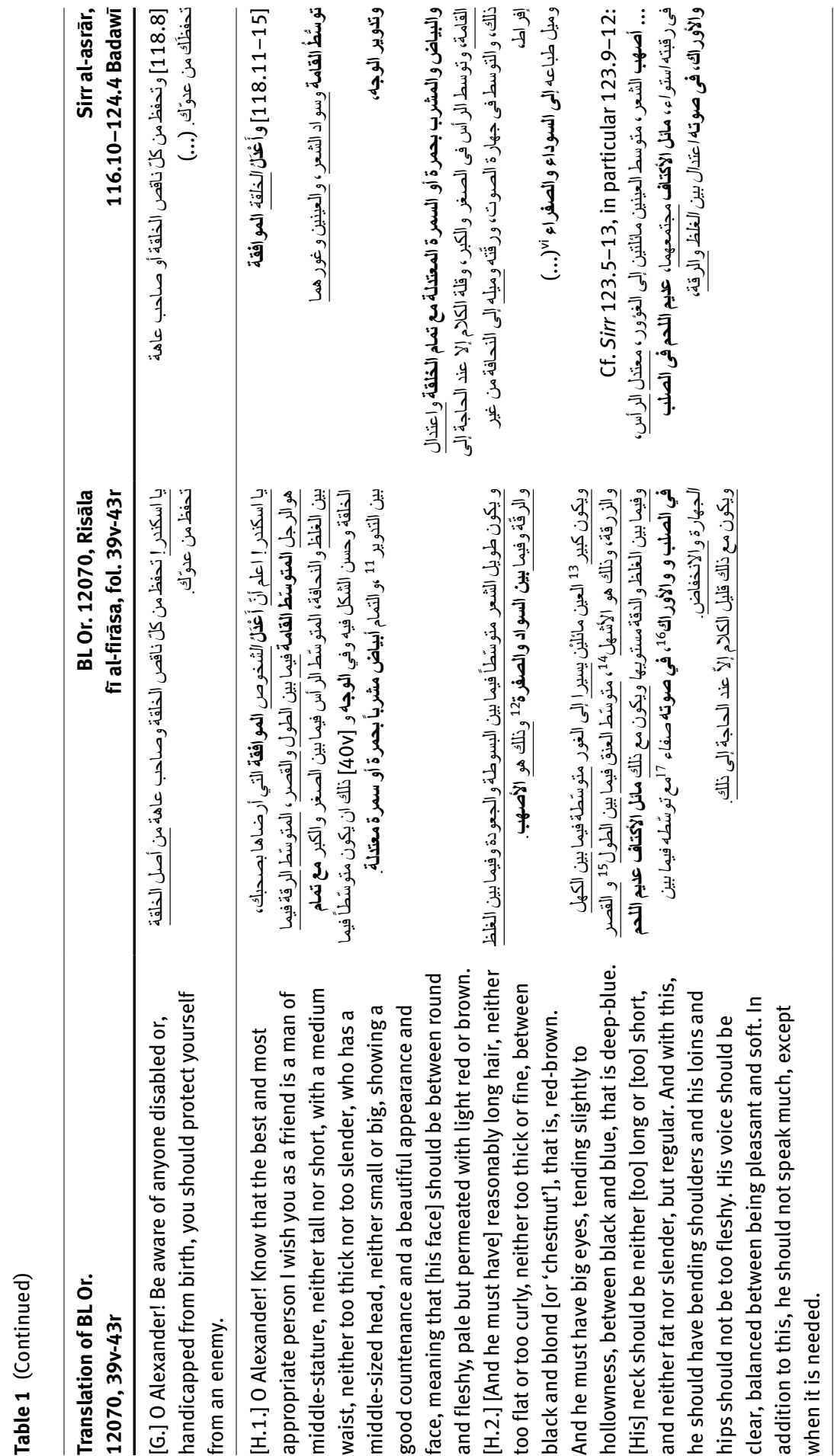




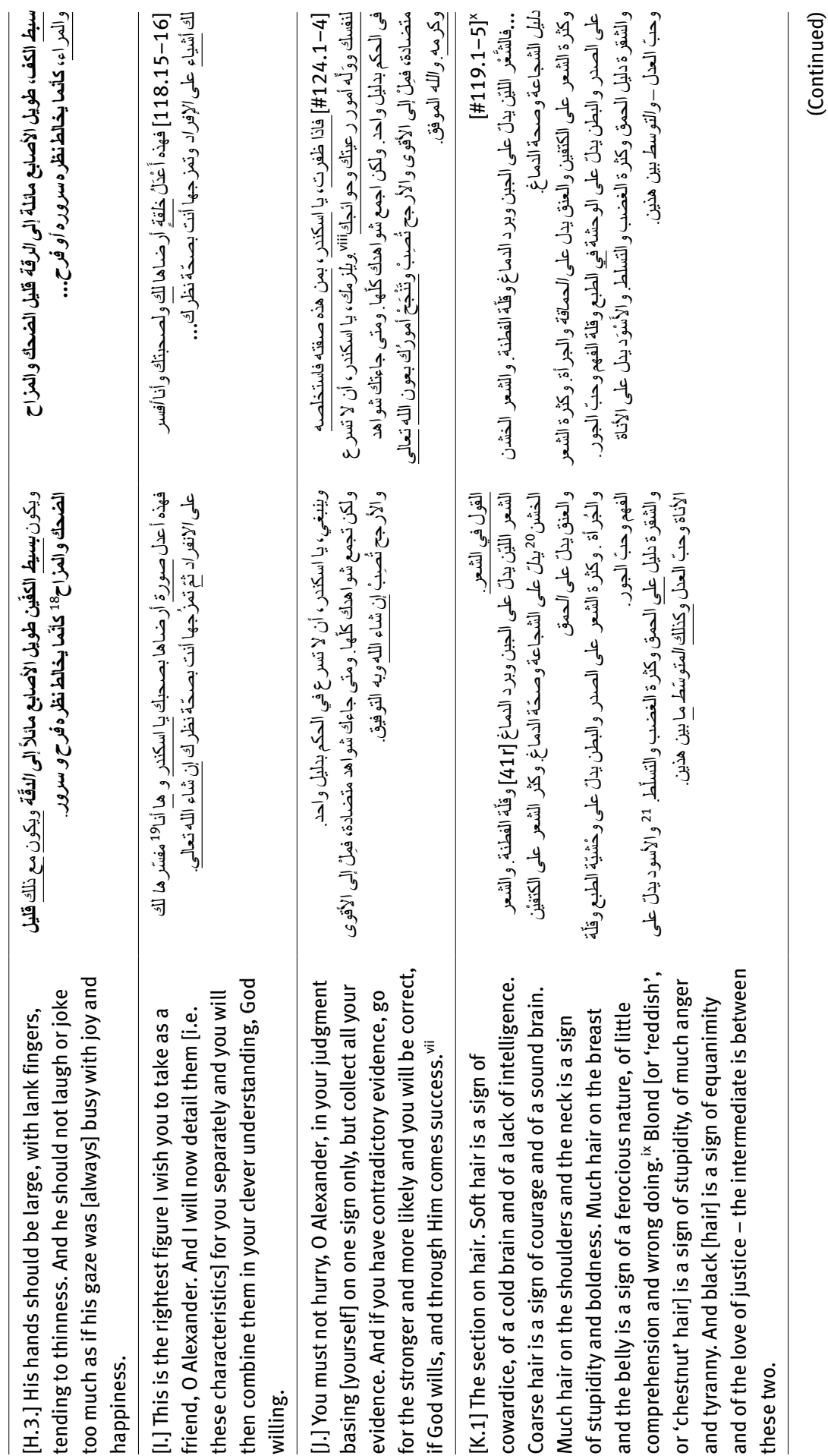




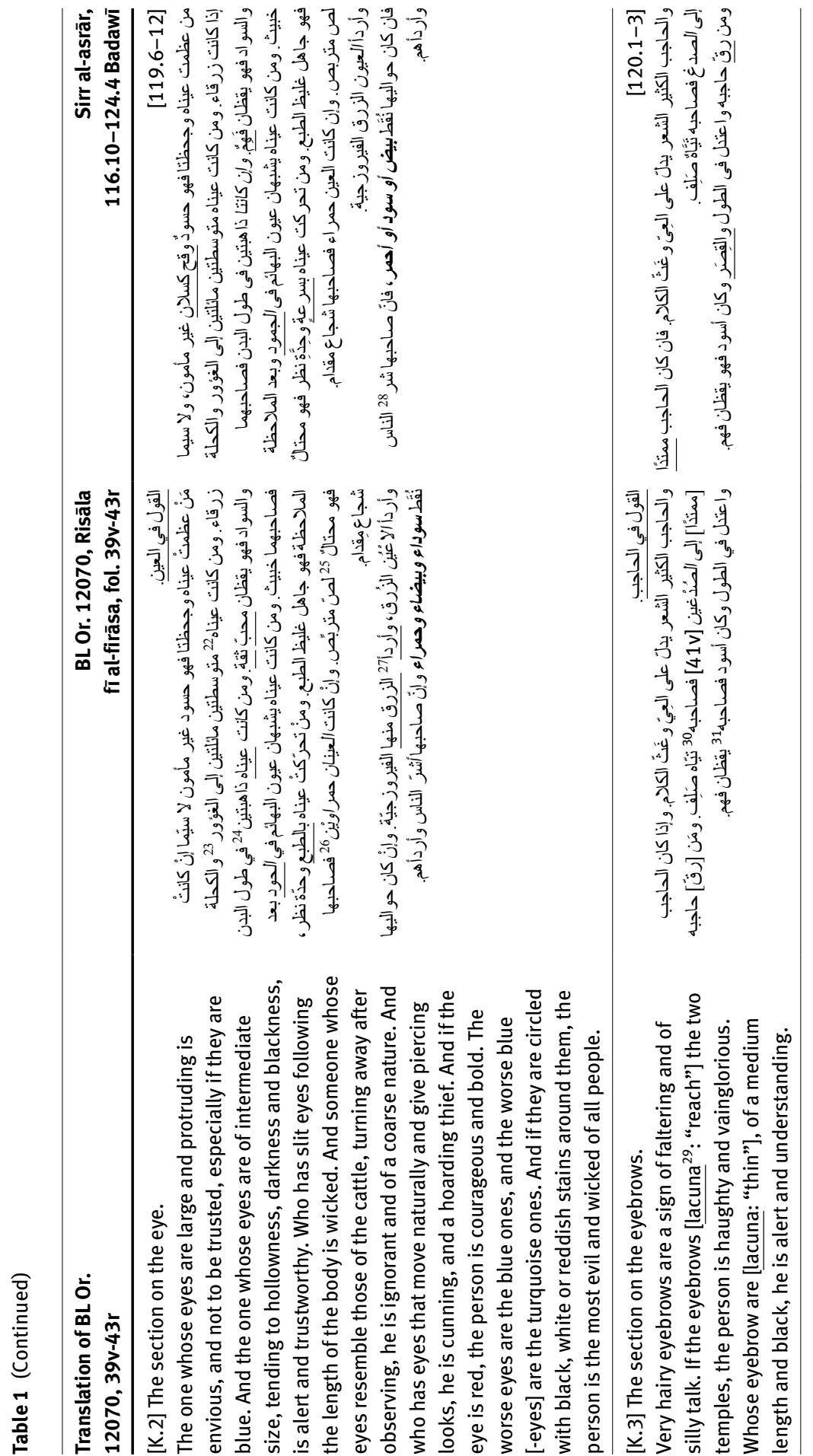




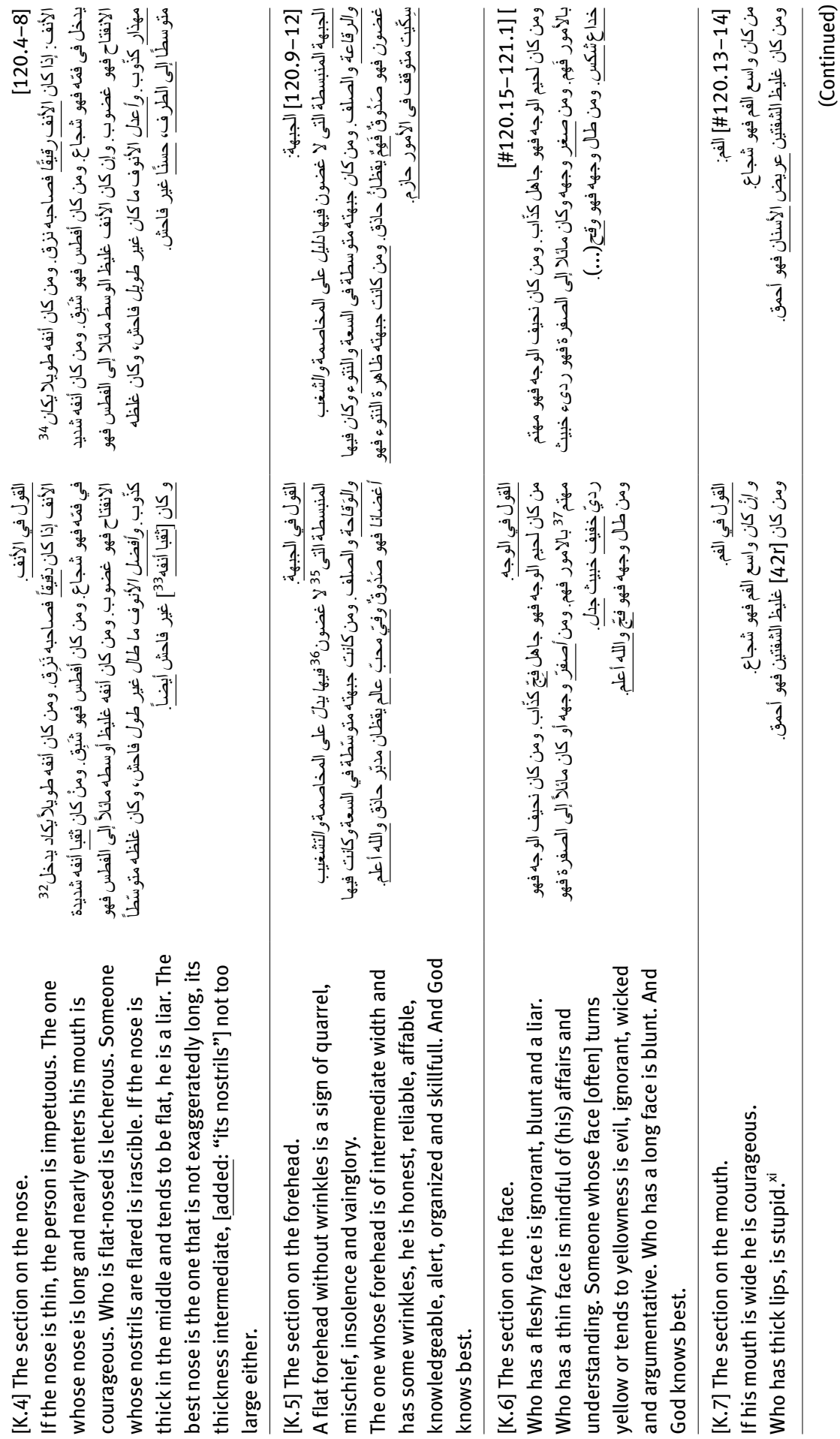




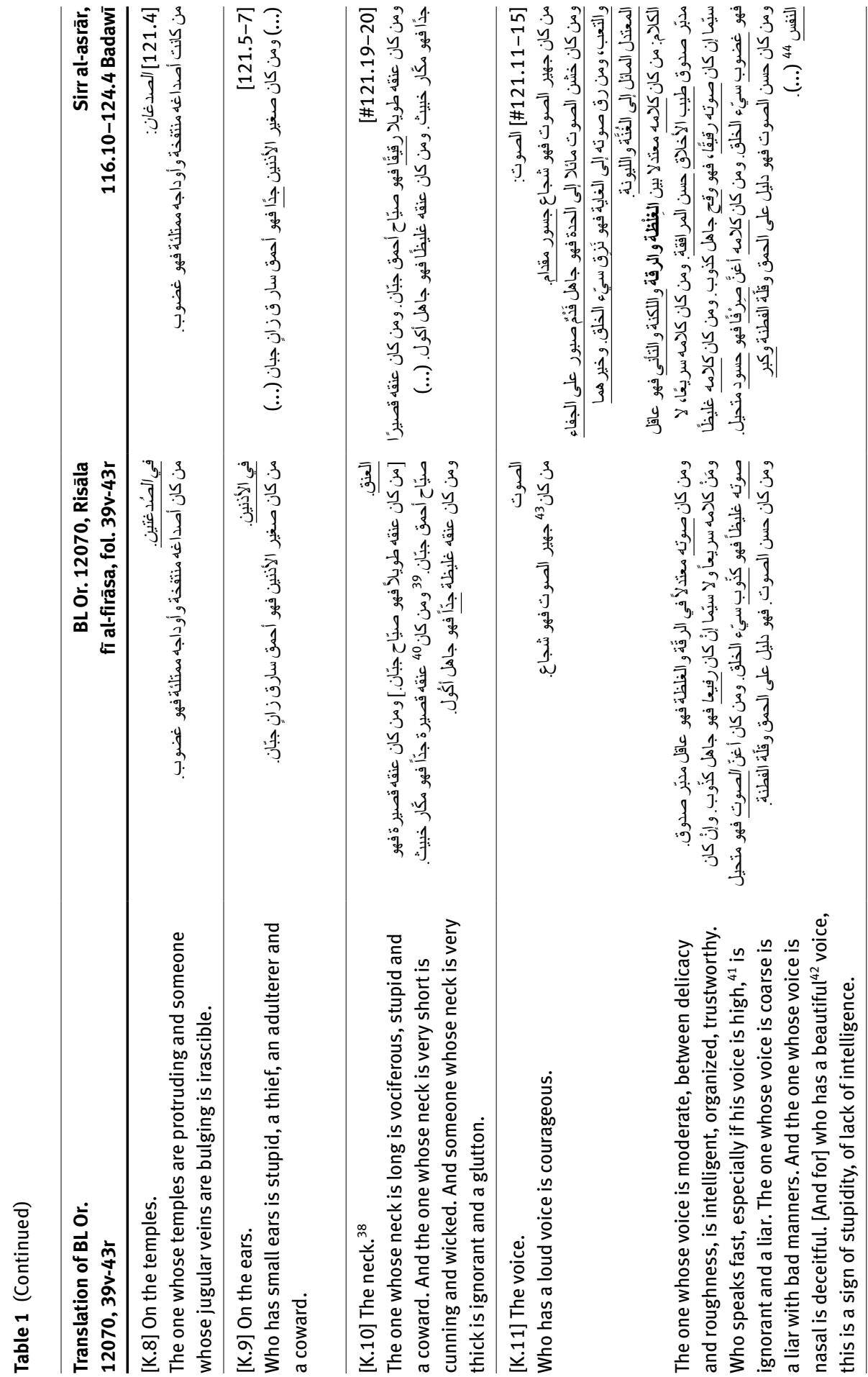



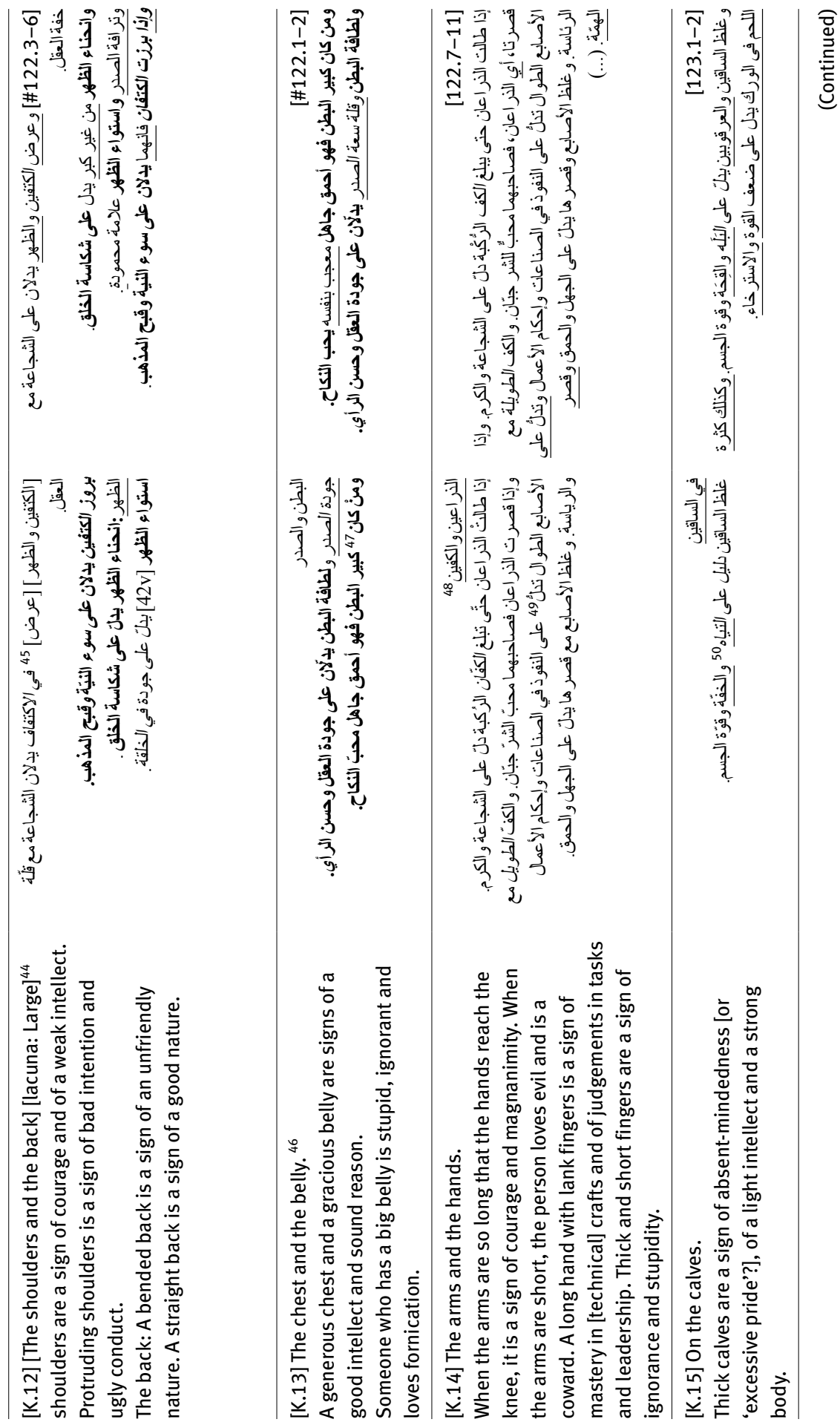


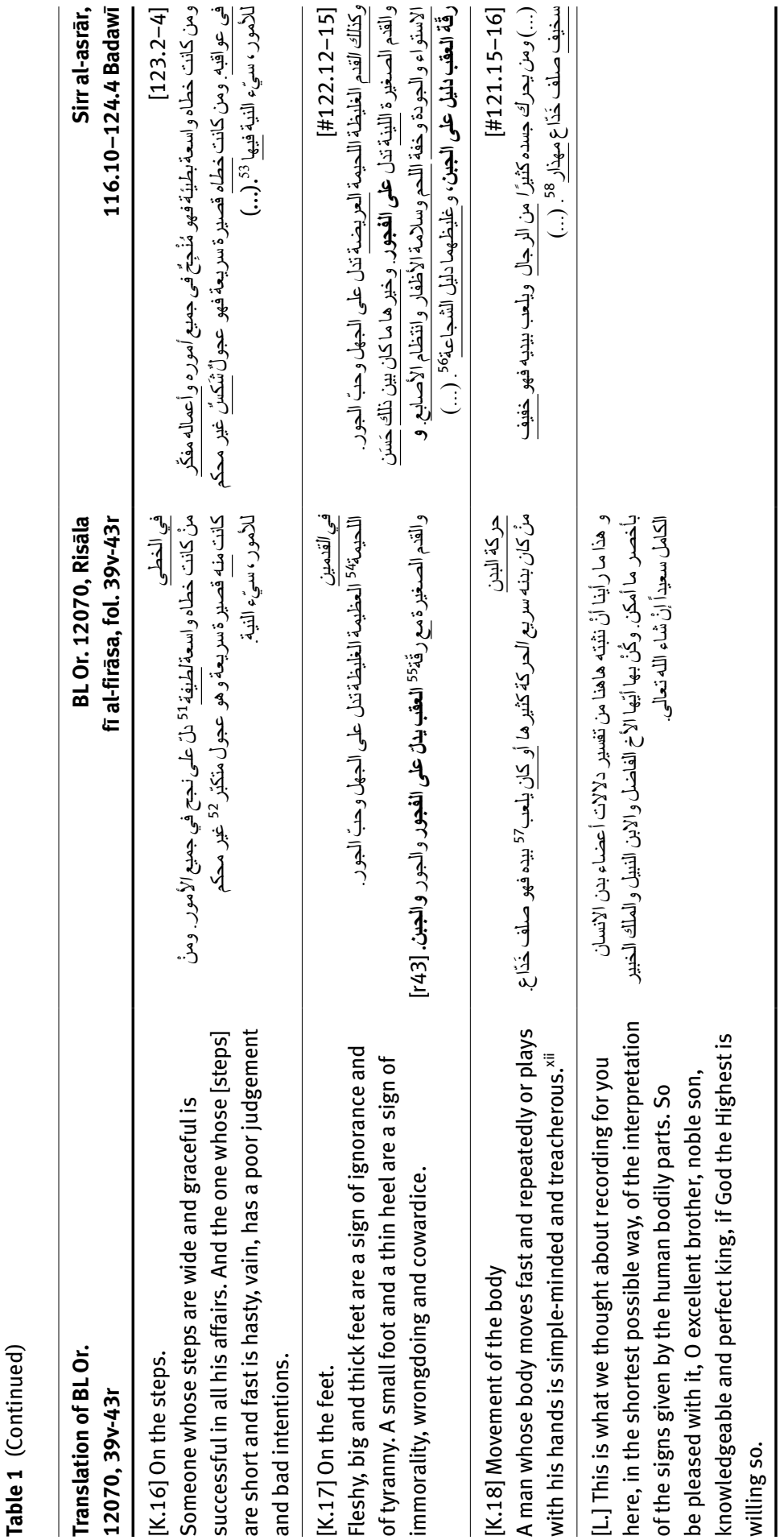




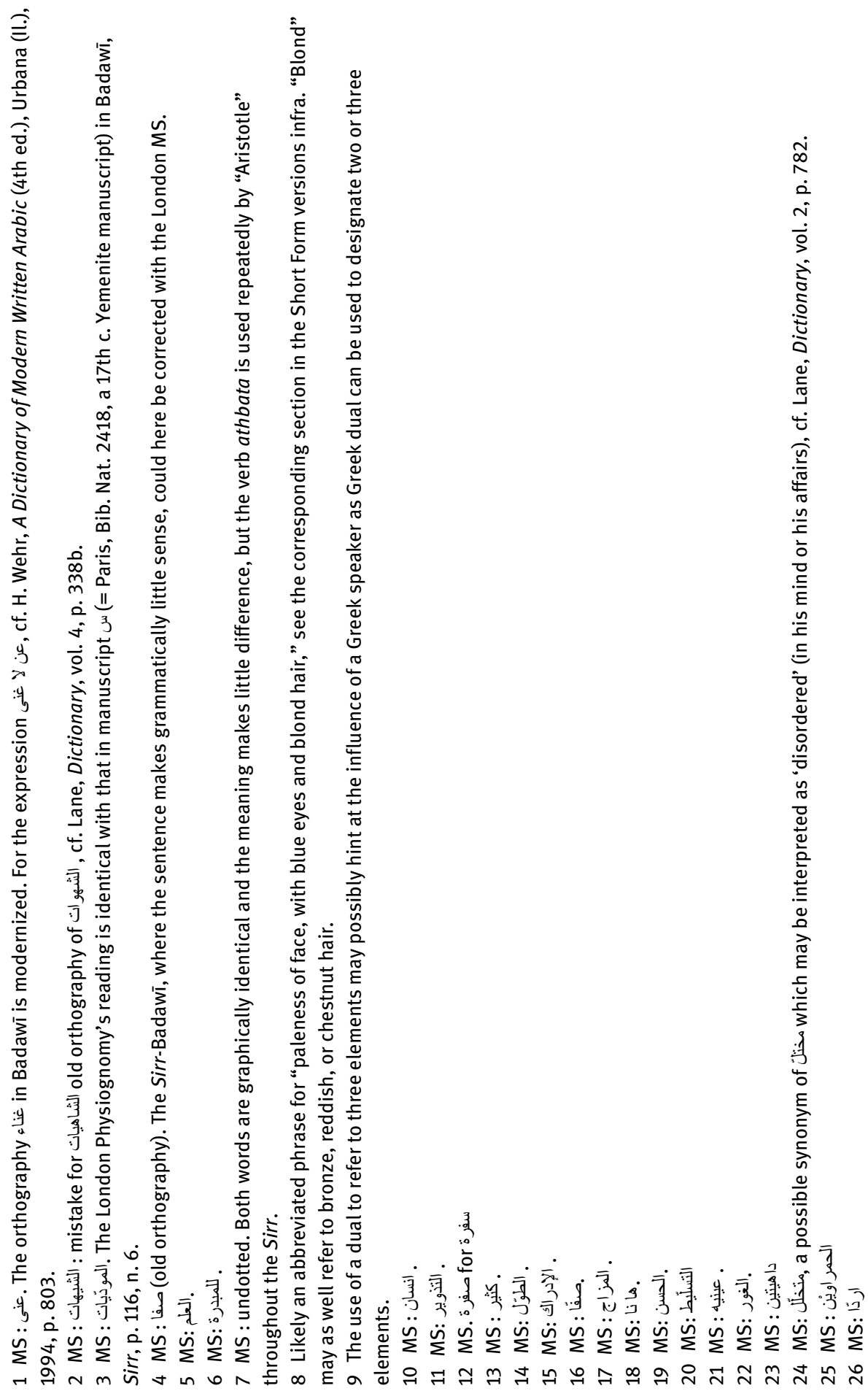




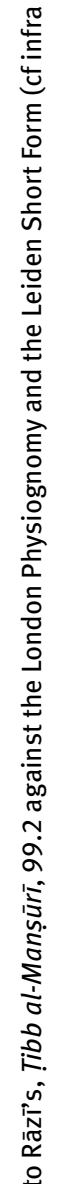

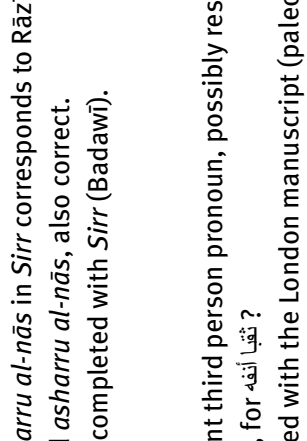

苑

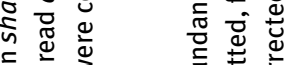

은

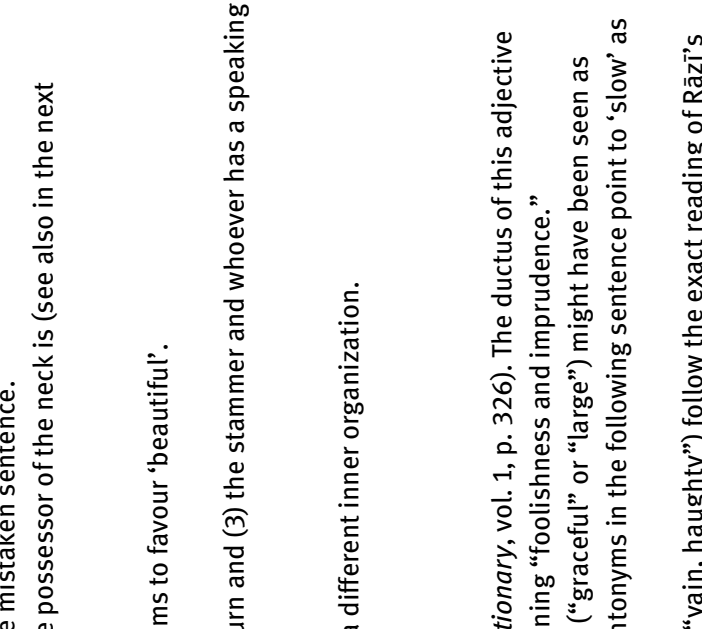

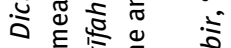

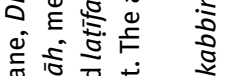

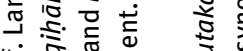

प्र $\frac{1}{1}$. 을 है

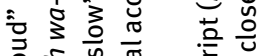

응 牙

잉

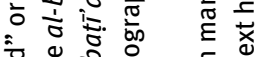

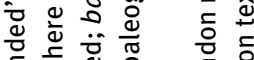

它芯范

है

证苛

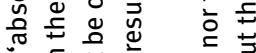

$\because .5$ 范

के

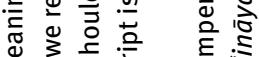

ङ $3 \frac{5}{5} \quad$

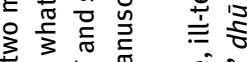

屯ै 'స

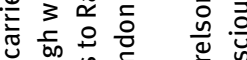

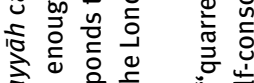

$\stackrel{8}{5}$

总

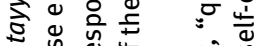
은

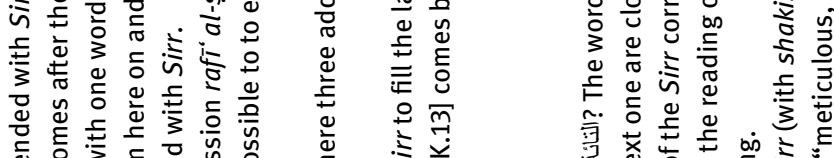

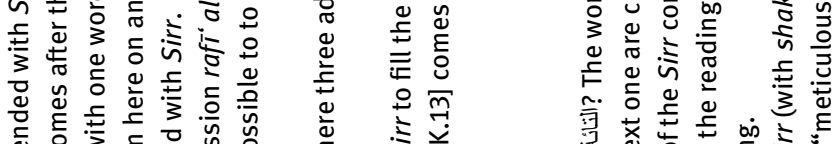

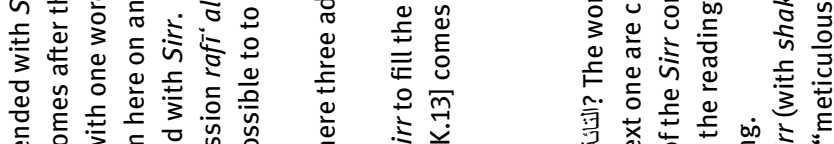

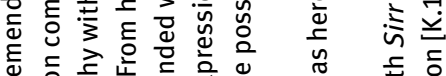

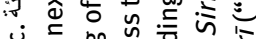

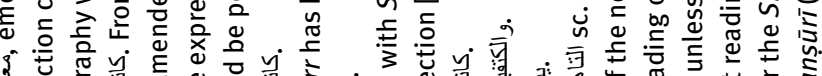

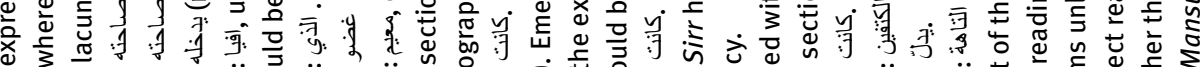

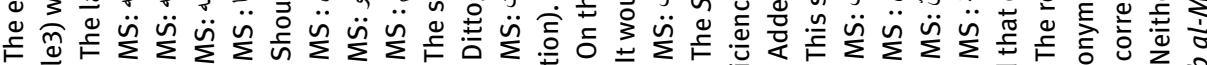
$\hat{A}$ 药 


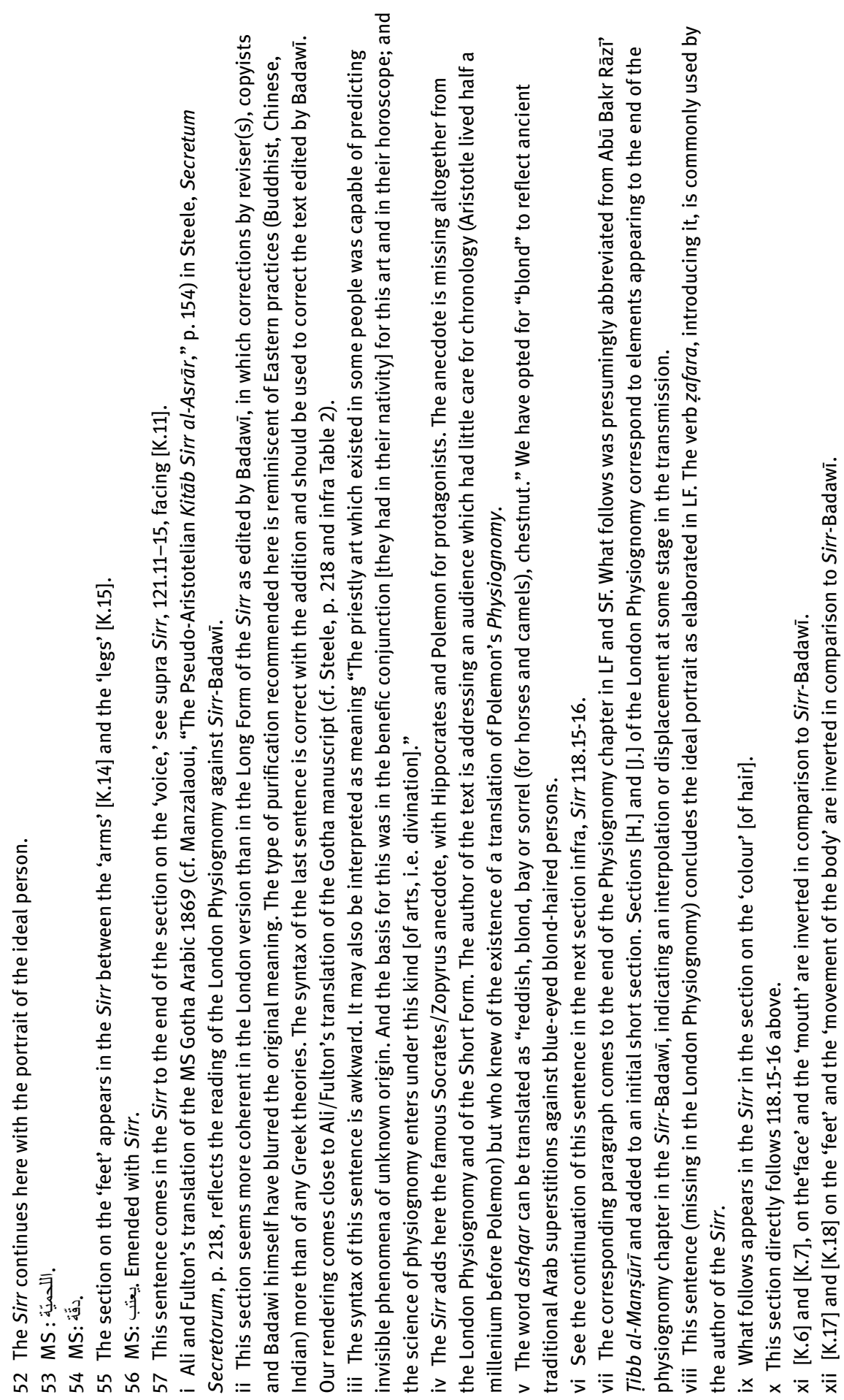


abbreviated from the Long Form, while agreeing at the same time on the possibility of a lost archetype from which both versions derived. ${ }^{85}$ Steele for his part suggested, following Förster, that the Long Form made a greater use of Abū Bakr Rāzī Ad Mansorem (i.e. the Tibb al-Manșūrī) than the Short Form, an expansion which seems to argue for Manzalaoui's hypothesis. ${ }^{86}$ Nevertheless, as will be seen in what follows, the London text simultaneously bears traces of the Long Form revisions and an organisation of the text that is closer to the one witnessed in the Short Form (see infra Tables 2 and 3 ).

This difference in the organisation of the text can be partly explained by the role played by the "ideal portrait," a summary of the bodily characteristics of the ideal figure whom Alexander should be seeking as a friend (in the London text) or as an advisor (in the Long Form). In the Sirr-Badawī, not one but two portraits are given. The first one is placed before the enumeration of the body parts (Sirr, 118.11-16 Badawī) while the second one appears at the conclusion of the chapter (Sirr, 123.5-13 Badawi). In the London text however, we find only one portrait, introduced by a statement of Aristotle [H.1], according to which if someone corresponding to these features could be found, Alexander should take him as a friend. The parallel in Sirr-Badawi gives a somewhat different portrait, introduced as an epitome of "the most harmonious and favorable composition (a'dal al-khalqa al-muwāfiqa)" (Sirr, 118.11 Badawī). The second portrait in LF is introduced by an original element, missing in the London text and in the Short Form versions (see infra Tables 2 and 3) in which Aristotle states that if such a character is found, he would be a suitable personal advisor to whom Alexander could delegate his affairs and the supervision of the subjects ( $\left.r a{ }^{4} \mathrm{i} y a\right) .{ }^{87}$ The comparison of the ideal portrait(s) will be discussed in a separate section (cf. infra The Ideal portrait(s)).

85 On the relation between SF and LF and Grignaschi's critics of Manzalaoui's thesis, see Grignaschi 1976, 15-16. Trying to verify his hypothesis by resorting to the London Physiognomy and to the relation of the SF and LF versions, Grignaschi summarized Förster's hypotheses on the Physiognomy and added a fully developed theory of the relations of the Physiognomical texts in Grignaschi 1976, 35-45, pointing to a dozen new texts discovered after Förster. A whole book would be needed to verify Grignaschi's suggestions. His understanding of the relation of SF and LF evolved throughout the decades he devoted to the Sirr al-Asrār, with what seems to be his final position expressed in Grignaschi 1982, 6. 86 Cf. Steele 1920, lxiii.

87 Grignaschi 1976, 43, noticed that the sentence is missing in three of the Arabic versions he used (Istanbul and two Gotha manuscripts) as well as from Philip of Tripoli's Latin translation. He believed that it should be considered an addition from the copyists of one of the later manuscripts of the Long Form used by Badawī. 


\section{The inner title of the Physiognomy section and the anecdote on Hippocrates and Polemon}

In the London text (Table 1, section [A.]) and in most versions of the Short Form (see infra Tables 2 and 3), a title is given to the section on Physiognomy at the beginning of the text with some minor variations. We find in the London text: "Epistle on Physiognomy (Risāla fĩ al-firāsa)"; in the Short Form: "Discourse on Physiognomy (al-Qawl fì al-firāsa)." In the Long Form however, this title appears in the middle of the introduction, following the anecdote about Hippocrates and Polemon which is missing from both the London text and Short Form. ${ }^{88}$ The author of the Long Form further adds in a comment missing from the Short Form, but extant in the London text (see Table 1, section [D.]), that the chapter was "abbreviated": "Abbreviated chapter on the Science of Physiognomy (Bāb mukhtașar fì 'ilm al-firāsa)" [Sirr, 117.12 Badawī]. Having in mind the comparison offered by Regula Forster of the SirrBadawī with Abū Bakr al-Rāzī's chapter on physiognomy in his al-Tịbb al-Manșūrī, one is tempted to consider this as a possible reference to Rāzī's full text. Grignaschi however, was under the impression that both Rāzi and the London text derive from a common source. ${ }^{89}$

The importance of this divergence between the texts is reinforced by the relationship between these sources and the Hippocrates-Polemon anecdote. In the London text, a cursory reference to Polemon appears (see Table 1, section [C.]) as one of the most famous authorities in the field of physiognomy, while the SirrBadawì has instead the anecdote about Polemon's commenting on Hippocrates portrait with the specification "Polemon, the author of the Physiognomy" (Sirr, 117.1). Both the London text and the Long Form of the Sirr then explain in a similar manner (see Table 1, [D.]) that what will follow has been abbreviated from a more complete text, as was just mentioned. But the London text has the addition "and this is where it starts (wa-hā hunā mubtadā' dhālika)" where the Sirr-Badawī 117.12. has what I have referred to as the "inner title," possibly once a title in the margin. A somewhat similar organisation of the contents appears in the Topkapi recension of the Arabic

88 Grignaschi 1976, 42-43, remarked that the Latin translation of Philip of Tripoli, a Long Form, has indeed two titles: one, "General physiognomy," preceding the short introduction and another one, "Particular physiognomy," before the detailed bodily parts. Using a 13th-century manuscript from Istanbul (MS Ayasofia 2890) which he believed was one of the oldest witness of the Long Form, Grignaschi adds that the manuscript lacks the second title or a reference to the body parts section as being abbreviated, and that the section belongs to Book II.

89 Grignaschi 1976, 40. In my opinion, Grignaschi overinterprets the variant between hasan and khashan. Both words are identical when undotted, but the mere presence of the word written undotted in a manuscript does not necessarily imply that the readers read it hasan rather than khashan. Correcting the Arabic with the Greek, as Grignaschi does, may also be misleading because of the possibility that a translation was verified with another manuscript and later corrected, thus leading to the recontamination of the tradition from an outside source. 
Polemon, in which Ghersetti remarked that the anecdote about Hippocrates and Polemon is given before the incipt of what is stated to be the book of Polemon, which is clearly identified by the words: "This book of his begins with his statement...".90 But the order is not the sole parallel between the Sirr and the Arabic Polemon. The London text and the Sirr-Badawi seem to echo the Istanbul text when we read that "Polemon [...] could determine from the constitution of a man his character (yastadillu bi-l-insān 'alā tarkīb nafsihi)" (cf. Table 1, Section [C.]).. We find an exact parallel in Badawi's edition of the Sirr (apart from the addition that Polemon was "the author of the Physiognomy" as mentioned above). The parallel sentence we read in the Istanbul Polemon betrays a more elegant translation: "He would determine the moral character [of a man] from his outer attributes (fa-stadalla 'alä l-khalq bi-l-khuluq)."91 The polysemic root kh-l-q might have caused some confusion to readers and possibilities of confusion are reinforced by the fact that khalq and khuluq share an identical ductus, خلق ${ }^{92}$ It is unclear whether the two versions represent two alternative translations or if the London text derives from Istanbul Polemon, via a series of intermediaries. The different transliterations of the names offered in the London text (Polemon: Aflìmūn) versus the Istanbul one (Polemon/Hippocrates: Afīlāmūn/ Hīwāfaqrāțīs) would argue for two different translations.

Returning to the oddly constructed sentence found in the Sirr-Badawi and in the London text, it is paralleled by a number of later witnesses to the anecdote, which are usually believed to be borrowings. One of them, Ibn Juljul (d. 987), whose Generations of the Physicians and the Sages (Țabaqāt al-ațibbā' wa-al-hukamā') was composed in 975 , is often quoted by later compilers. ${ }^{93}$ His testimony is of particular value because he is one of the first authors to mention the Sirr al-Asrār explicitly. ${ }^{94}$ However, Ibn Juljul's knowledge of the anecdote may have been borrowed directly from Polemon's Firāsa rather than from the Sirr, as can be deduced from the introductory lines to the anecdote about the encounter between Hippocrates and Polemon: "And it is what Polemon the author of the Physiognomy was stating in his [Book on] Physiognomy (wa-dhālika anna Aflimūn șāhịib al-firāsa kāna yaz'amu fī firāsatihi)." ${ }^{95}$ But the use by

90 Ghersetti 2007a, 465, 476-477 for the text and translation. See the remarks of Hoyland 2006, 317. 91 The verb istadalla can be constructed with the particle bi- or with the particle 'ala with an identical semantic value; Arabic is unfortunately not as clear as German in this regard. Arabic text and translation in Ghersetti 2007a, 468-469. The confusion is attenuated by the addition of "and from his outward [appearance] towards his inner [nature] (wa-bi-l-zāhir 'alā l-bāțin).”

92 For the meanings of khalq and khuluq, see Lane, Dictionary, vol. II, s.v. khalq, p. 801c. Khalq is often use in ninth-century Arabic to refer to "humans in general" (for example in Jāhiz's writings), most probably derived from the religiously connoted expression khalq Allāh, i.e. "God's creation."

93 See supra n.47.

94 He is in fact the first author to mention the Sirr al-Asrär under this title and to give a number of quotations which can all be found literaly in the textbook we possess today. See Ibn Juljul 1955, 17 and Forster 2006, 17, nn. 65 and 66.

95 Ibn Juljul, Ṭabaqāt al-ațibbä’ wa-al-ḥukamä’, 17.9-11 Sayyid. 
Ibn Juljul directly afterwards in the same sentence of the phrase yastadillu bi-l-insān 'alā tarkīb nafsihi rather than the more elegant version found in the Topkapi Polemon, seems to confirm the possible existence of two distinct translations. ${ }^{96}$ Ibn Abī Ușaybī'a, a thirteenth-century physician who quotes repeatedly from Ibn Juljul in his encyclopaedic work on the history of medicine, makes use of a small variant on one occasion: wa-ahkkama 'alā akhlāq nafsihi min tarkībihi with ahkama ('to judge') instead of istadalla ('to determine, to deduce'). Ibn Abī Ușaybī'a, who had access to the main Ayyubid libraries of Cairo and Damascus, also bears witness to the existence of a recension of the story closer to the classical version, where Socrates appeared instead of Hippocrates. ${ }^{97}$ Hence, all the testimonies of the anecdote may ultimately be derived from an original close enough to the version known to Ciceron (involving Socrates and Zopyrus) who reports that “Zopyrus [...] claimed to discern every man's nature from his appearance...". 98

Finally, some epistemological affinities between the Topkapi Polemon and the Sirr can be detected. The theoretical introduction of the Topkapi Polemon's justifies physiognomy as a development of medical practices. According to Ghersetti, the author of this introduction based himself on Plato's theory of the tripartite soul in the Republic and on humoral physiology. ${ }^{99}$ She adds that the introduction of the Arabic Polemon should not be ascribed to the celebrated Greek physiognomist, but to another author. ${ }^{100}$ Traces of humoral theory applied to the description of the favourable features may also be found in the different versions of the Sirr's physiognomy, as will be seen in the comparative tables below.

\footnotetext{
96 Ibn Juljul mentions the anecdote although it is usually agreed that he knew a Short Form version (loc. cit., 17 and 67 Sayyid, where Ibn al-Bițīiq's Fundgeschichte is quoted from the Sirr in the very exact wording of the MS Leiden, Or. 749, an SF8, against the variants of the Sohag manuscript, another SF8 witness, quoted by Sayyid in his notes, loc. cit., 69. Could it be that Ibn Juljul's version had been annotated and should we consider the possibility that the anecdote was once part of some marginalia on a Short Form manuscript available in tenth-century Cordoba?

97 Ibn Abī Ușāybi'a, 'Uyūn al-anbā', vol. I, 28.1-2 Müller, quoted by Hoyland 2006, . 315.

98 Hoyland 2006, 315, cf. Ghersetti 2007b, 282, n. 4, and the references given there to Cicero, Tusculean Disputations and On Fate.

99 Ghersetti 2007b, 284; Hoyland 2006, 318-319 develops the philosophical and medical aspects of physiognomy and relates the pseudo-science with the widespread Arabic literary genre of "Correction of characters (tahdhīb al-akhlāq)".

100 It is possible to say that its theoretical introduction was certainly available to the Shiite philosopher Miskawayh (d. 421/1030), as can be shown from the detailed answers he gave to Abū Ḥayyān al-Tawhīdī (d. ca 414/1023) on the definition and purposes of physiognomy (Hawāmil wa-Shawāmil, $\mathrm{n}^{\circ}$ 63, 163-171 Amīn/Saqr). The book, a four-hand composition resulting of Tawhịdī and Miskawayh's epistolary exchanges was titled Hawāmil wa-Shawāmil ("The Roving [questions] and the Exhaustive [answers]" as a token of its genesis, as underlined by the pun on Hawāmil, which has the meaning of "carriers"). I used the Cairo 2009 reprint of the A. Amīn and A. Saqr edition, the pagination of which differs from Hoyland. Hoyland mentions the Hawämil among the witnesses of the anecdote and notes the influence of the Topkapi Polemon (Hoyland, "Polemon's encounter," 317, n. 16). Hoyland is unintentionally misleading in ascribing to Tawhīii the statements made by Miskawayh (Hoyland 2006, 313-314 and 317-318), which leads him to date the Topkapi Polemon according to Tawhìdī's dates.
} 


\section{The bodily characteristics}

Some brief remarks can be made about the section devoted to the physical characteristics of each bodily parts and the interpretation they suggest. The comparison of the London text with the Sirr-Badawi shows that both texts are almost identical in a number of sub-sections, once the paleographical slips are recognized. The main divergences appear in the ordering of the parts of the body, especially in the second half of the text. The main difference, however, lies with the portrait(s) of the ideal physical characteristics, to which we will turn in the next section. The attempts made by Manzalaoui to reconstruct the transmission by basing himself on the order of the bodily parts were not fruitful. ${ }^{101}$ His main witness, the Sohag manuscript (Sohag [Egypt], Municipal Library, History 167), is criticized by Grignaschi as inferior to the better text preserved in the other witnesses of the Short Form. ${ }^{102}$ As will be explained in what follows, Grignaschi's own reconstruction suffers from a number of mistakes and approximations. It is worth mentioning too that one manuscript of the Short Form version (Oxford, Laud. 210 = W in Steele's siglae) is said to have the characteristics and their qualities in the form of tables. This type of presentation could well be the reason for some of the discrepancies observed in the different versions of the Physiognomy. ${ }^{103}$

[K.1] "on the hair"104 to [K.4] "on the nose" are almost identical with minor scribal omissions and stylistic adaptations. [K.5] "on the forehead" has in Sirr-Badawi an addition about the "protruding forehead." This rather rare feature might have been seen as irrelevant by the copyist of the London text who decided to skip it or it may have been altogether missing from the text he had before his eyes. In this section, a number of adjectives are different in the London text and in the Sirr-Badawi but they are generally simple synonyms, with a tendency to rarities and archaisms in the London Physiognomy (which generally follow the identical formulation of the Short Form, as will be seen in Tables 2 and 3 ).

More variants can be detected in the section of the 'face' [K.6]. They might be explained by a reviser's adaptation of the text to his own tastes, although a number of variants may also be the result of paleographic corruptions (by the reviser or some copyist): rare fijj ("rude") is replaced in one of its two occurences with waqih "impudent shameless," which might be considered a synonym. But the graphical proximity

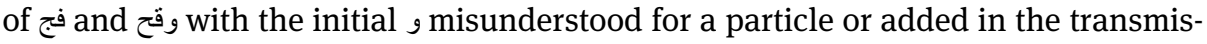
sion process calls for some prudence. Similarly jadil, rarely used as an adjective might

101 Manzalaoui 1974, 222-223.

102 Manzalaoui 1974, 149; Grignaschi 1976, 15.

103 Grignaschi 1976, 15, wrongly refers to the tables of the Leiden manuscript, in addition to those of the Oxford one.

104 The "soft hair" designating "cowardice" and the "coarse hair" pointing to "courage" already appear in the Pseudo-Aristotle’s Physiognomy, see Ghersetti 1999, 21, 1. 5; Swain 2007, 640(Gr.)/641(tr.). 
have been replaced with khadā' shakis, unless خداع should be seen as a corruption of جدل. The original word is more likely to have been jadil جدل reinforced in Sirr-Badawī by resorting to a hendiadys, resulting in khadā' shakis.

In comparison to the Sirr-Badawī, the London text also inverts the order of the sections on 'face' [K.6] and 'mouth' [K.7], with Sirr-Badawī following the order (but not necessarily the contents) of Rāzì's Tỉbb al-Manșūrī. In the Gotha manuscript used by Ali and Fulton for Steele's study of Roger Bacon's commentary of the Secretum Secretorum, we find in the section on the 'face' a fully coherent portrait, going from 'face' to 'cheeks' and 'beard,' that is missing in the London Physiognomy, where we find instead elements corresponding to the Short Form (see infra Table 3). ${ }^{105}$ In [K.7] the reference to the characteristics of the 'teeth' is missing in the London text which is otherwise identical with Sirr-Badawī. It was possibly dropped by the copyist because he considered it as anecdotal and wanted to abbreviate his model (it consists of just two words within a sentence on the 'lips'), or it was missing in his text. The repeated use of "And God knows best (wa-Allāhu a'lam)" at the end of some sections [K.5] and [K.6] points to the author's puzzlement at his model(s) and possibly as to the London text abbreviating its model(s). Rāzī’s Ṭibb al-Manșūrī (p. 100 al-Ṣiddīqī) has more details on 'teeth' but they differ entirely from Sirr-Badawī.

Despite some strong divergences, Mario Grignaschi believed there was a common model from which the Sirr and Abū Bakr al-Rāzī would have borrowed. His study of the differences in the body-parts sections from one version to another (including the London Physiognomy) led him to believe that rather than a mere borrowing to Rāzì's text, we should admit the existence of a common source, which he calls the "Ancien épitomé arabe." However, the argument is impaired by a degree of imprecision. Grignaschi states about the characteristics of the 'voice' that the oldest manuscripts ${ }^{106}$ of the Sirr would have preserved a trace of Polemon when we read that a "coarse voice" ("la voix rude" in Grignaschi) is a sign of "stupidity." ${ }^{107}$ But the matter is more complex than Grignaschi seemed to believe. For the text of Polemon (269.6 Förster), which Grignaschi quotes solely in Arabic, ${ }^{108}$ has in fact no literal parallel in any version of the Sirr. The closest sentence ("waman kāna ḥasan al-ṣawt fa-huwa dalīl 'alā al-ḥumq wa-qillat al-fiṭna”) appears at the end of the 'voice' section. However, this section differs in the London text from

105 Steele 1920, 222, cf. Table 1, section [K.11] and Table 2, 222 for the comparison of the Gotha text translated by Ali/Fulton with the London text.

106 Grignaschi 1976, 40. What Grignaschi sees as the oldest Sirr manuscripts is an odd mixture where we find together the Istanbul Ayasofia 2890, the Oxford Laud. Or. 210, the Berlin Sprenger - with no further precision, but most probably he is referring to Ar. 943 - and the Sohag manuscript used by Manzalaoui (cf. Manzalaoui 1974, 221).

107 Grignaschi 1976, 40-41.

108 Grignaschi 1976, 40, n. 3: wa-thiql al-șawt al-musta'jil yadullu 'alā al-ḥumq wa-qillat al-fuṭna [sic]. 
what we read in either Badawī's edition or Ali/Fulton's translation. The section [K.11] as we find it in the London Physiognomy has only a section on the 'voice (al-șawt)' while Sirr-Badawì (121.11-15) has two sub-sections, one on the 'voice' and one on the 'speech.' In the Gotha text as we find it translated in Steele (p. 222), the two sub-sections on the voice and on speech are part of a larger section on the 'face', where they follow a discussion of the 'ears.' Also misleading is Grignaschi's statement that the error appears in the manuscripts of Razi's Tibb al-Mansuri: the al-Șiddīqi edition used by Regula Forster (see her article in this volume), where the sentence can be found on p. 101, has khashan, i.e. "coarse." As to the Paris manuscript quoted as evidence by Grignaschi, it does read hasan ("beautiful”) which seems to be the correct reading if we recognize that the short paragraph (where discussions of the 'voice,' șawt, and 'speech,' or 'language' here rendering kalàm, are alternately given) has already mentioned twice the "coarse voice (man kāna șawtuhu ġaliz)" and the "heavy voice (man kāna șawtuhu thaqìlan)" in the three preceding lines. ${ }^{109}$ The indication in Rāzì that a "beautiful voice (husn al-sawt)" is a sign of "stupidity" and of "coarse nature" is completed in the SirrBadawī and in the London text with "vainglory." 110 The same imprecision can be found in the London text [K.11], where the 'loud' (jahir) voice has been addressed at the beginning of the section (as in Sirr-Badawī 121.11) while the 'coarse' voice ('galiz $)$ has been attached to lying and bad manners. In Sirr-Badawī however, the sentence differs, and it is now stated that someone who uses "coarse language (kalām)" is irascible and of bad manners. The fluidity of such texts (and the common practice of correcting previous translations either to adjust the Arabic or to suggest a new translation), make any reconstruction of the stemma on the sole base of the variants an impossible task. Resorting to the Greek "originals" (when those can be identified with any certainty!) should not go without caveats. The evolution of the vocabulary within Arabic, a conservative language which has managed to go on for centuries using the same grammar and syntax, is displayed by the choices made by copyists, whose role is to adapt the text they copy to their audience and to possible dialectal evolutions. Arabic writing and its common use of scriptio defectiva in manuscripts leads to paleographic homographs which in turn are attemptively deciphered by copyists of various degrees of expertise. Retrieving the original Greek behind adaptations is therefore hazardous.

The order of the London text for [K.12] 'shoulders' and 'back,' followed with [K.13] 'chest' and 'belly' differs from Sirr-Badawī and Abū Bakr Rāzī, where we find the 'belly' and the 'back' before the 'shoulders' and the 'back.' Contrary to the London text, where they are distinguished, Sirr-Badawì and Rāzì have the characteristics

109 Grignaschi 1976, 40, n. 4.

110 As noted by Grignaschi 1976, 40, where he offers the correct translation "la sottise, une nature peu douée et l'orgueil." 
related to the 'back' inserted within the sentences addressing those of the 'shoulders.' For the 'shoulders' and 'back' section, the vocabulary employed in the description varies widely but can be reduced to a mere choice of synonyms and a different construction of the sentences. In Sirr-Badawī we find the 'belly' and the 'chest' together in one sentence, while the London text has the 'chest' first. It seems that the London text is here sticking more closely to the head-to-heel description than the versions of Rāzī and the Long Form as in Sirr-Badawī.

The section of the 'arms' and 'hands' [K.14] is almost identical in the London Physiognomy, the Sirr-Badawī, and Rāzì. Interestingly, the positive characterization of long arms "reaching to the knees" (!) ultimately stems from the Pseudo-Polemon. ${ }^{111}$ It is intriguing that, as was underlined by Professor Kenneth Zysk in an oral intervention during the conference, this characteristic is commonly encountered in Indian literature, where it refers to the warrior-king and to the Buddha. ${ }^{112}$ Hopefully, these proceedings will participate in enhancing our understanding of Polemon's sources, or alternately that of Indian literature.

On the 'calves' [K.15], the comparison reveals that Sirr-Badawī is closer to Rāzī than the London Physiognomy. The characteristics of the 'thighs' are missing in the London text, while Sirr-Badawī stems from Rāzī or the latter's source. Some paleographical accidents in the transmission can also be recognized: Rāzī's al-balah ("foolishness") and al-nafkha ("conceit") becomes al-balah and al-qihā ("impudence") in Sirr-Badawī. It seems likely that القِحَةion the result of a corruption of النفخة. On its side, the London text reads al-tāh possibly for tayh (n.) or $t \bar{a}$ 'ih (adj. used here improperly), likewise meaning "conceit"113 and al-khiffa الخفة resulting from the paleographic corruption of البلة and النفخة.114

On the 'steps' [K.16], the London Physiognomy appears to be standing somewhere between Rāzī and the Sirr-Badawī. They all appear to be closer to the PseudoAristotle's Physiognomy - which for the other sections does not seem to show much affinity with the Sirr - than they are to the Arabic Polemon. ${ }^{115}$ However, it is possible to find in Adamantius a possible echo of what we read in the Sirr witnesses and in Rāzī. These exemples demonstrate the fluidity of a text like this to the utmost degree. In particular, before concluding that there were in fact two different translations, attention should be paid to the semantic evolution of adjectives, which made constant revisions by the copyists and translators a necessity.

111 Hoyland 2007, 408 (Ar.)/409 (tr.), Bāb 21/B19; Repath 2007, 524 (Gr.)/525 (tr.), B19.

112 See Zysk 2015, 165; 648; 741.

113 Lane, Dictionary, vol. I, p. 326, s.v. $t-y-h$.

114 For possible influence, see Hoyland 2007, 400 (Ar.)/401 (tr.), Bāb 9/B9; Repath 2007, 520 (Gr.)/521 (tr.), B9.

115 The Pseudo-Polemon seems entirely unrelated to the Sirr for this section, see Hoyland 2007, 438 (Ar.)/439 (tr.), Bāb 50/B39. 
London text: "Someone whose steps are wide and graceful (wāsi a lațîfa) is successful in all his affairs (dalla 'alā najh fì jamī̄ al-umūr). And the one whose [steps] are short and fast (qașira sarīa) is hasty ( $a j u \bar{u} l$ ), vain (mutakabbir), has poor judgement (ghayr muhkam li-l-umūr) and bad intentions (sayy' al-niya).”

Sirr-Badawī, 123: "Someone whose steps are wide and slow (wāsi'a bațīa) is successful in all his affairs and his deeds (fa-huwa munajjịh fī jamī umūrihi wa-a mālihi) and thoughtful of consequences (mufakkir fi 'awāqibihi). The one whose steps are short and fast (qașira sarī $a$ ) is rash, quarrelsome ('ajūl shakis), has poor judgement (ghayr muhkkam li-l-umūr) and a bad intention in them (sayy' al-niya fīhā).”

Abū Bakr al-Rāzì, al-Ṭibb al-Manșūrī, 124: "One whose steps are wide and slow (wāsi'a bațī'a) is deliberate and successful (fa-huwa muta'annin munajjih). One whose steps are short and fast is rash ('ajūl), does mind [his] affairs (dhū 'ināya bi-l-umūr) but does not judge them well (ghayr muhkam lahā).”

Adamantius (B39): "Those who take large steps accomplish every deed and are great-minded (megalonoi). Those who take small steps are unsuccessful, bitter, and some are also parsimonious and thievish in character and make secret plots. (...) If a man walks quickly (...) he provides reliable signs of parsimony and cowardice and mischief and meanness. (...) The man who is swift but who takes small steps, is greedy, villainous and a consummate coward."116

Pseudo-Aristotle: "Someone whose steps are wide and slow (wāsi a bațī'a), he is successful (munajjịh), efficient ( $n \bar{a} f i d h)$, steady in his ambitions (muta'ayyid [sic for mutta'id?] fimā yaqșud), and this is because wide steps are a sign of success (najh) while slow steps are a sign of deliberateness (tu'ada) and perseverance (al-anā). Someone whose steps are short (mutaqāriba) but slow, he is unsuccessful and not [or: "but remains"] firm in his ambitions (ghayr munajjih muta'ayyid), and this is because short and slow steps are a sign of failure (al-taqșir). And someone whose steps are wide (wāsi'a), he is successful, thoughtful about things (bāhith 'an al-ashyā'), and this is because quick steps are a sign of completion while their wideness is a sign of success. And someone whose steps are short and fast (mutaqäriba sarīa), he is thoughtful but unsuccessful."117

In the section on the 'feet' and 'heels' [K.17], we find in Sirr-Badawi a great number of details missing from the London text. Details such as the best "foot" being one with "even toes" and a "soft flesh" might have been considered as superfluous by the redactor of the London Physiognomy. Grignaschi, noticing a different organisation of the sections ('legs,' 'steps,' and 'feet' in both the Short and Long Forms of the Sirr; 'feet,' 'legs,' and 'steps' in the London text), thought that this could be used as an argument against Manzalaoui's hypothesis that the London Physiognomy was a "mixed version" somehow intermediate between the Short and 
the Long Form. But nowhere does Manzalaoui state that the London text should be placed in a stemma between the Short and the Long Form; rather, he argues that the London Physiognomy derives from a missing common ancestor of these two versions. ${ }^{118}$ In turn, the organisation might also be explained by the different point of insertion of a section on the 'movements of the body' [K.18]. In the Leiden Polemon, these indications are found at the end of the section on 'walking and movement,' that is, directly alongside the mention of the 'steps' ${ }^{119}$ This section, oddly situated in the Leiden Polemon between the 'hair of the eyebrows' and the 'breath', seems to have been inserted in various positions in the different Sirr witnesses.

The section on bodily characteristics concludes in the London Physiognomy with a summarizing statement of "Aristotle" to "Alexander" [L.] while the Long Form inserts within its own, slightly different, concluding statement, a reference to the use that should be made of one sign or more or of the eventuality of contradictory signs (Sirr-Badawī, p. 224). The Sirr's Long Form follows here a similar organisation as Abū Bakr al-Rāzī (see in this volume the paper of Regula Forster, referring to Rāzī, Ṭibb al-Manșūrī, 107 Șiddīqī). This element, which appears in the London text before the bodily parts [J.], is ultimately derived from Adamantius's epitome (A3), where it is found in the prologue. ${ }^{120}$ The insertion of additions from scrap papers added at different stages of the transmission should certainly be taken into account, as they are not uncommonly found during the inspection of a manuscript. Short-lived and most often uncatalogued, they hinder any attempt to make a stemma based solely on the organisation of the sub-sections in a text whose thematic structure already guarantees some form of fluidity. Paleographical mistakes (to some degree), scribal corrections and omissions cannot be taken as the sole evidence for the reconstruction of a complex transmission, even more so when a great number of manuscripts remain inaccessible to researchers. Without making more manuscripts available to readers for comparison, no conclusions can be made and the same goes for the very little-knowledge we have of Abū Bakr al-Rāzì’s works, almost entirely lost or unpublished. ${ }^{121}$

118 Grignaschi 1976, 46, n.1; Manzalaoui 1974, 223.

119 Hoyland 2007, 438-441 (Ar./tr.), Bāb 50/B39-40.

120 Repath 2007, 496-497.

121 According to Ibn Abī Ușaybi a, 'Uyūn al-anbā', vol. I, 314 Müller, we owe the preservation of some of Rāzī's books and the edition of his magnum opus, the Kitāb al-Ḥāwī, to the efforts of the Buyid vizier and scholar Abū al-Fạ̣l Ibn al-'Amīd (d. 971) 


\section{Table 2: The Long and Short forms of the Sirr's Physiognomy}

Before turning to the ideal portrait(s) in the different witnesses of the Sirr, we should address some of the questions raised by Badawì's edition and its comparison to the Ali/Fulton translation published by Steele in his own study of the Sirr al-Asrār. ${ }^{122}$ The comparison of the London Physiognomy with Steele's text shows that the latter cannot explain the discrepancies between the London text and the Long Form. Badawì's text is close enough to the Long Form manuscripts used by Ali/Fulton but in one significant case, an element reminiscent of the formulation of the Short Form is present in Ali/Fulton but missing in Badawī. The purpose of this table is two-fold: (1) it helps to make clear the kind of criticism that can be addressed to Badawī, whose footnotes to the text should not be considered as a real apparatus criticus; (2) it also betrays some short-comings in Steele's publication of Ali and Fulton's translation, particularly in the way they provide the variant readings of the different manuscripts in their notes on the translation of the Long Form (apparently, only when they considered them significant) and chiefly among them, the variants and additions of a Short Form manuscript preserved in Oxford. Unfortunately, they give no precise information about the inversions between elements or their diverging ordering, so that as much as in the case of Badawī, resorting to Steele's study of the Physiognomy chapter should not be done without caveats. In the footnotes to Table 2, we have reproduced Ali and Fulton's own notes on their translation in toto, so that the alternative text offered by the Oxford Short Form (MS Laud. Or. 210) could be easily followed. Interestingly, Ali and Fulton's text happens to be extremely close to Gaster's translation of a thirteenth- or fourteenth-century Hebrew version, based on the Short Form. This seems to reflect a close relationship between the Oxford manuscript and the manuscript used by Gaster for his edition and translation (MS London, British Library Or. 2396). ${ }^{123}$ We have supplied the references to the parallels in Gaster in the footnotes in order to facilitate future studies of the Short Form versions. The parallels between the London text and the Short Form are addressed in the two next sections and the Appendix.

122 Only as "A.S. Fulton," about whom I could not find any information, appears on the cover of Steele's edition of Bacon's commentary to the Sirr and the English translation of the Arabic text attached to it. Ismail Ali and Fulton worked (the latter as an editor of Ali's text) under the supervision of Steele, cf. Steele 1920, vii.

123 On Gaster's edition, see Spitzer 1982, 34-54. Spitzer noticed the use of Gaster's translation by Ali and Fulton and lamented it. Nevertheless, as the comparison with the Leiden manuscript will put in evidence (see infra Table 3), the two seem to present a remarkable homogeneity. 


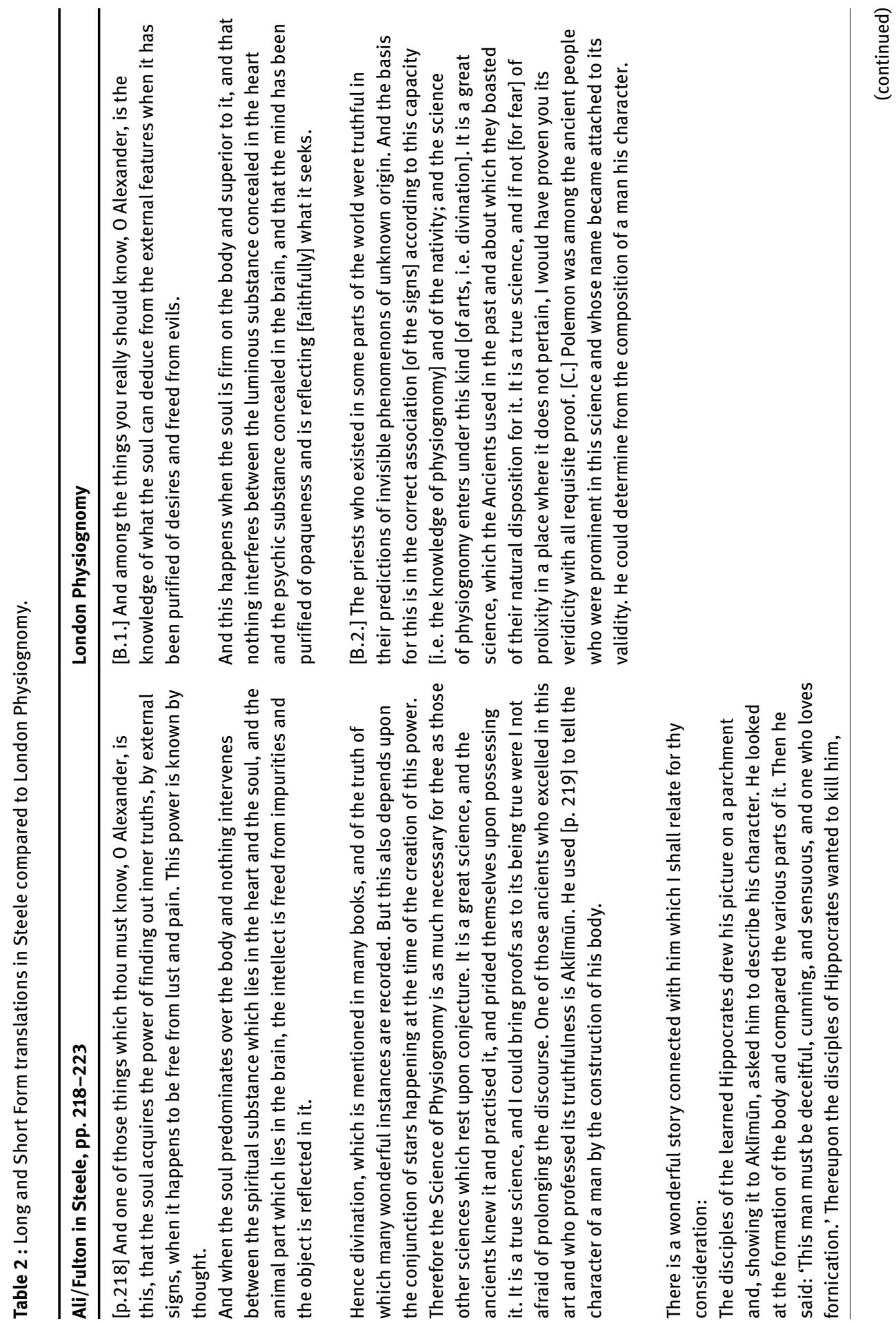




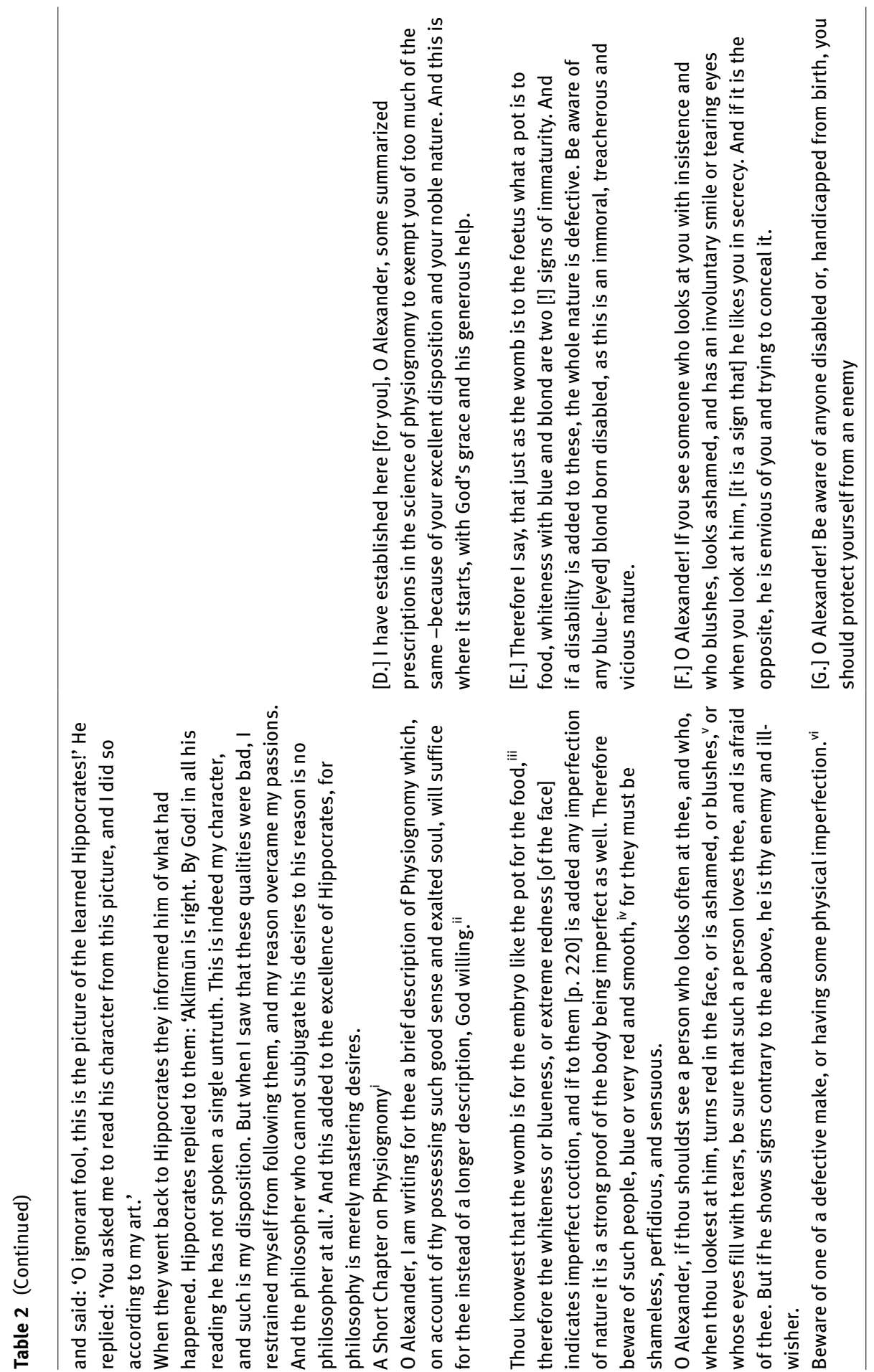




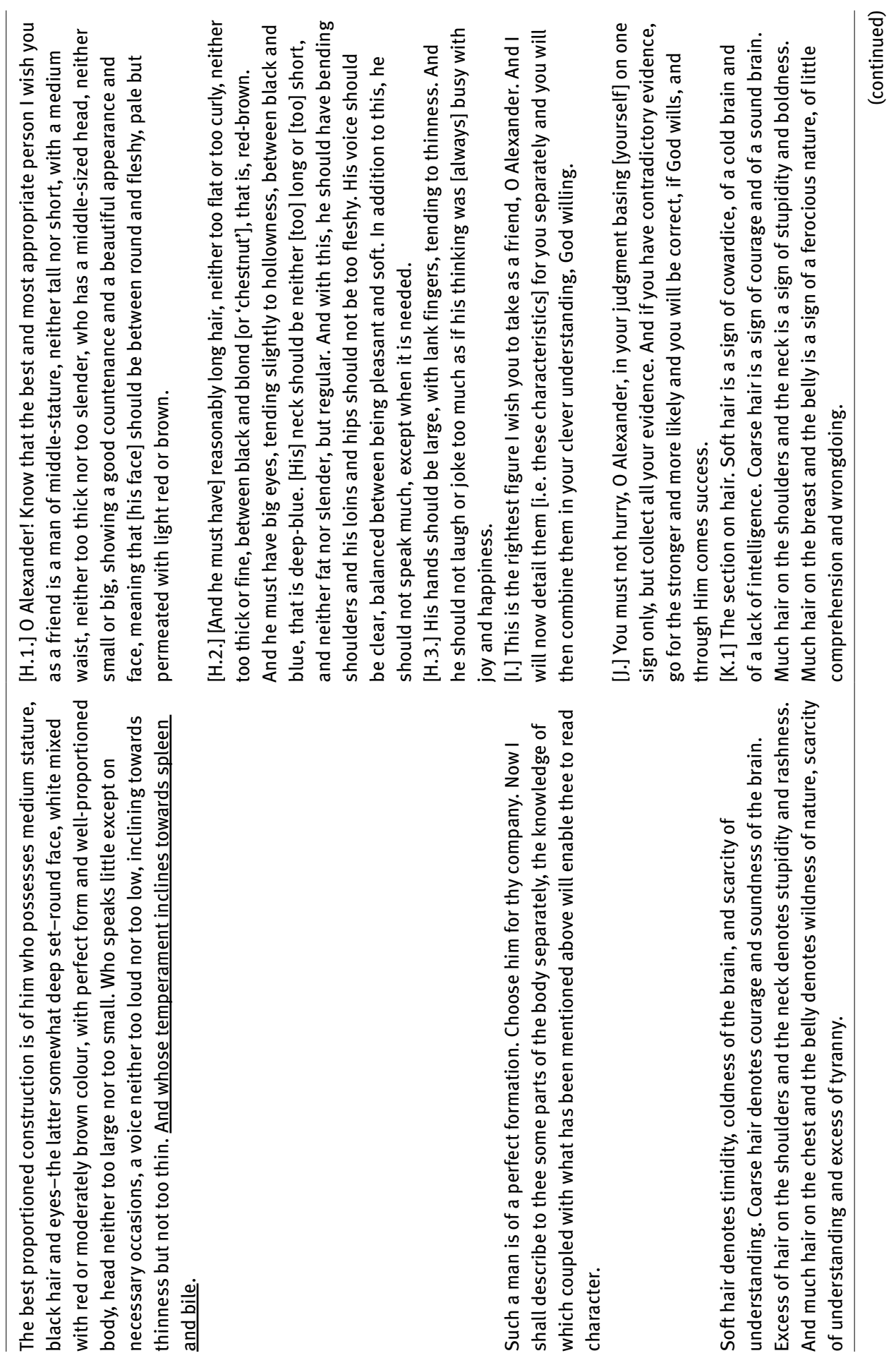




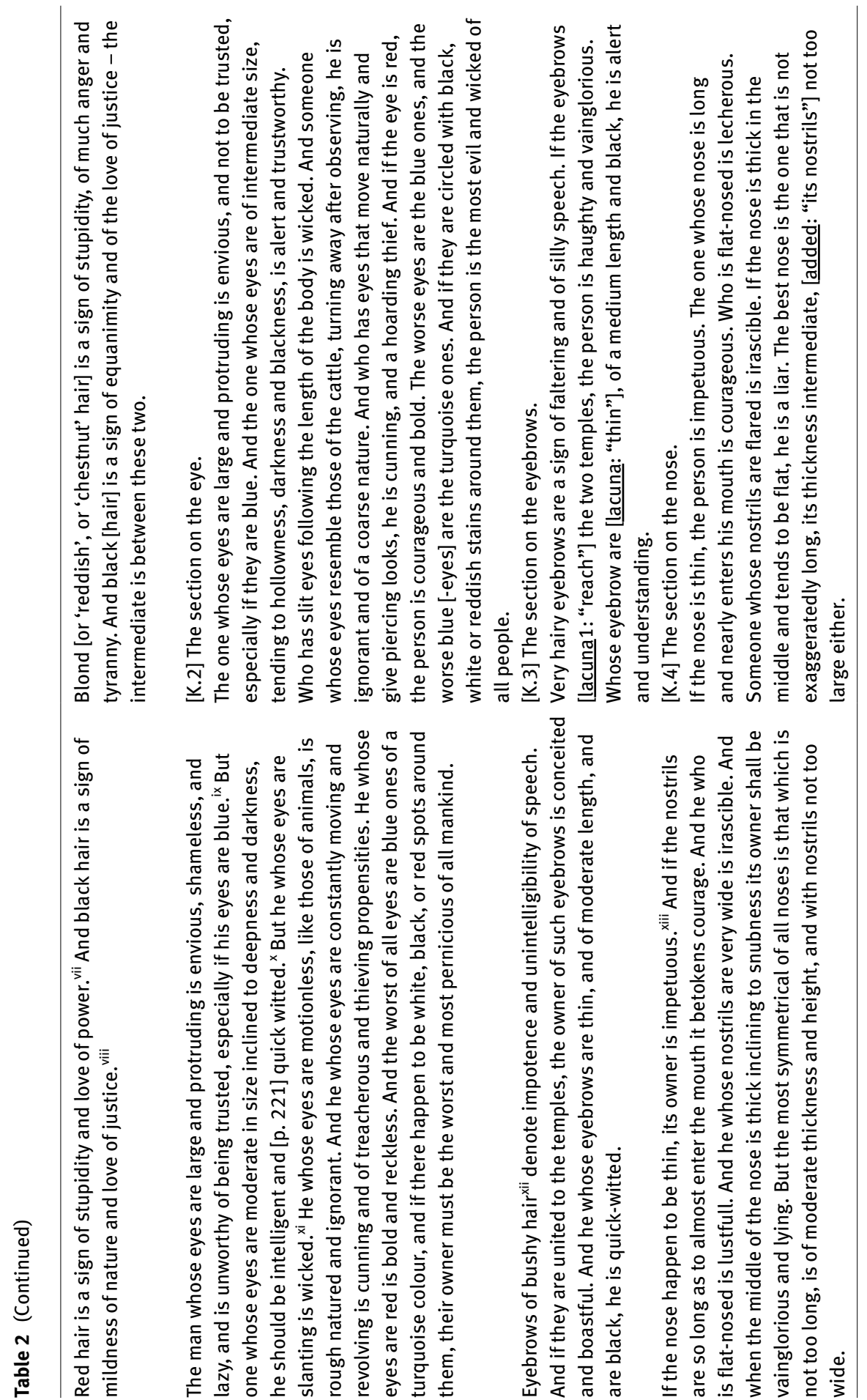




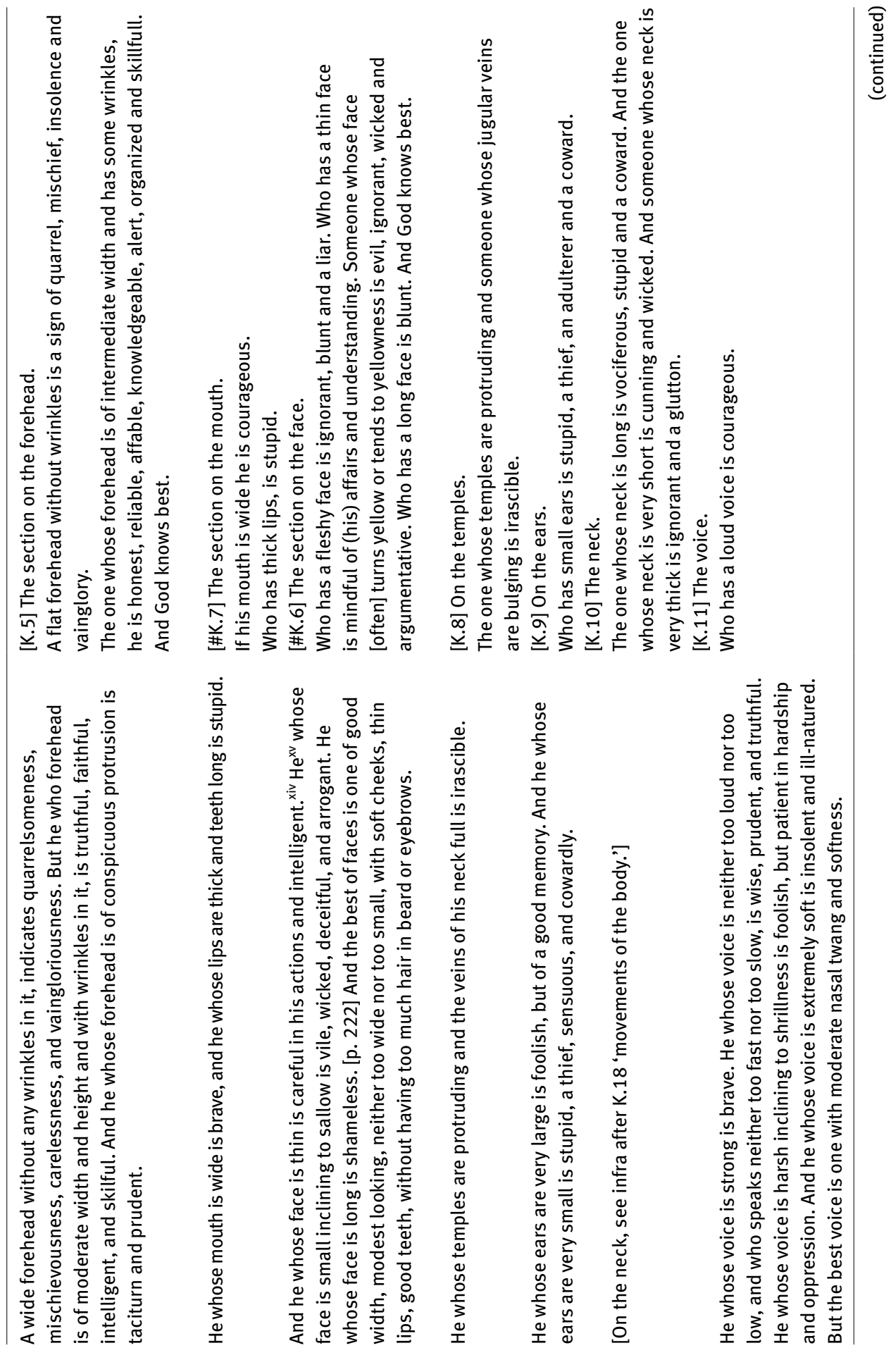



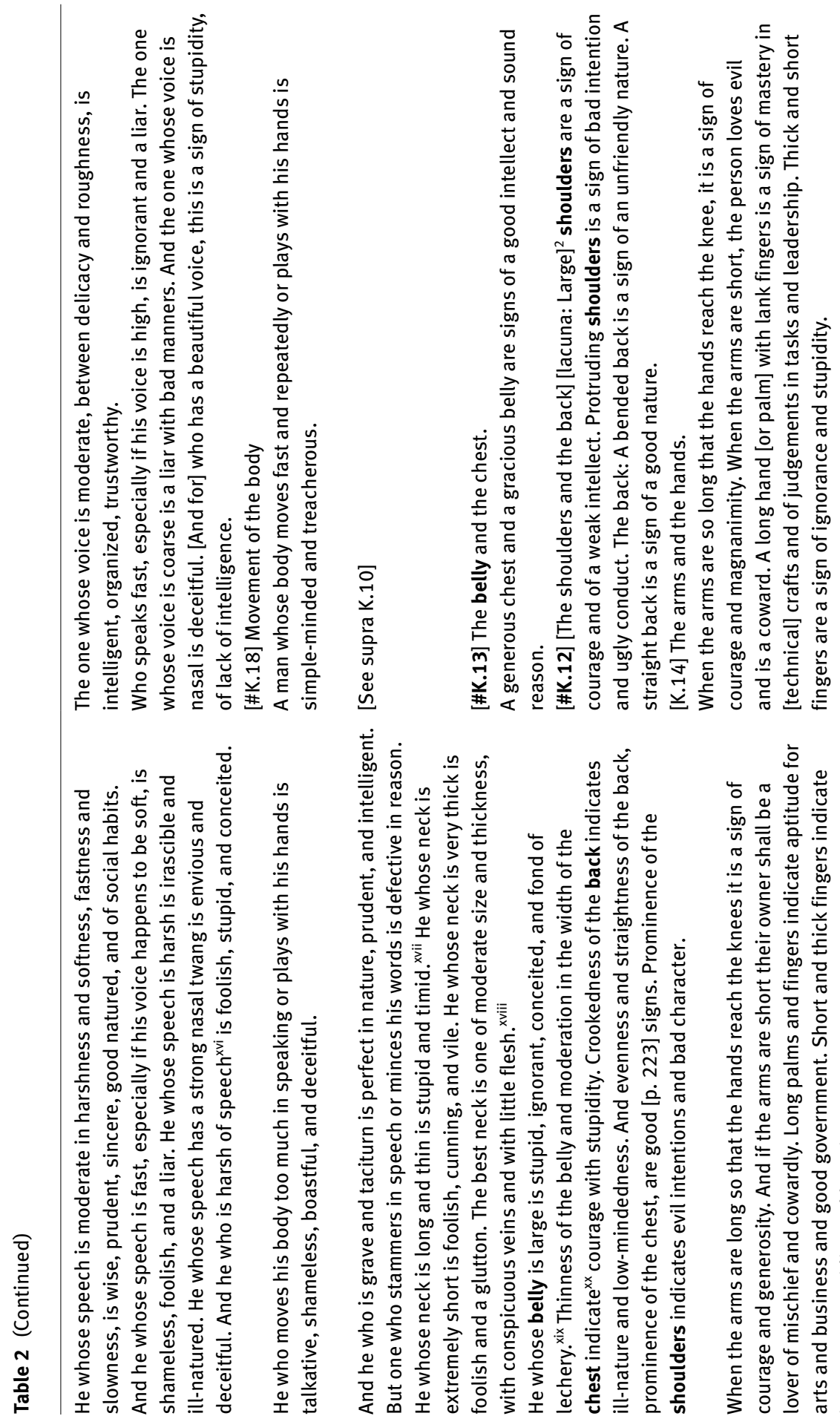

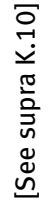

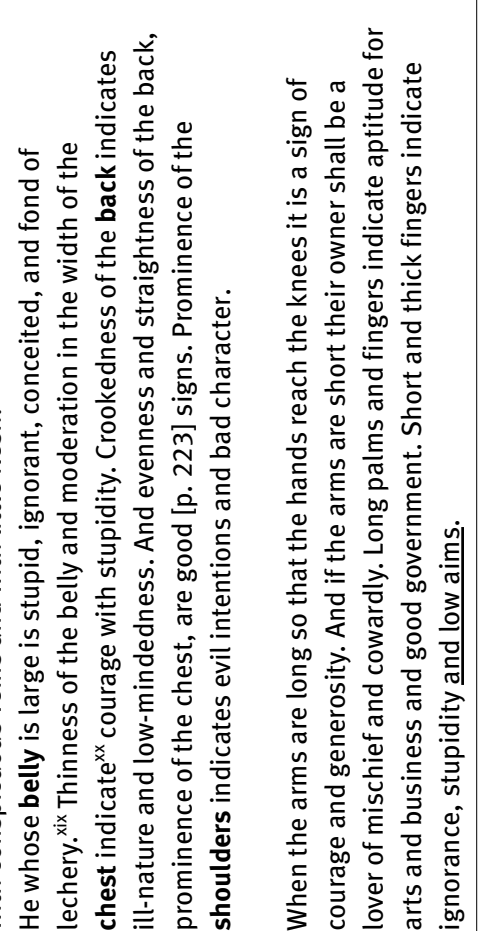



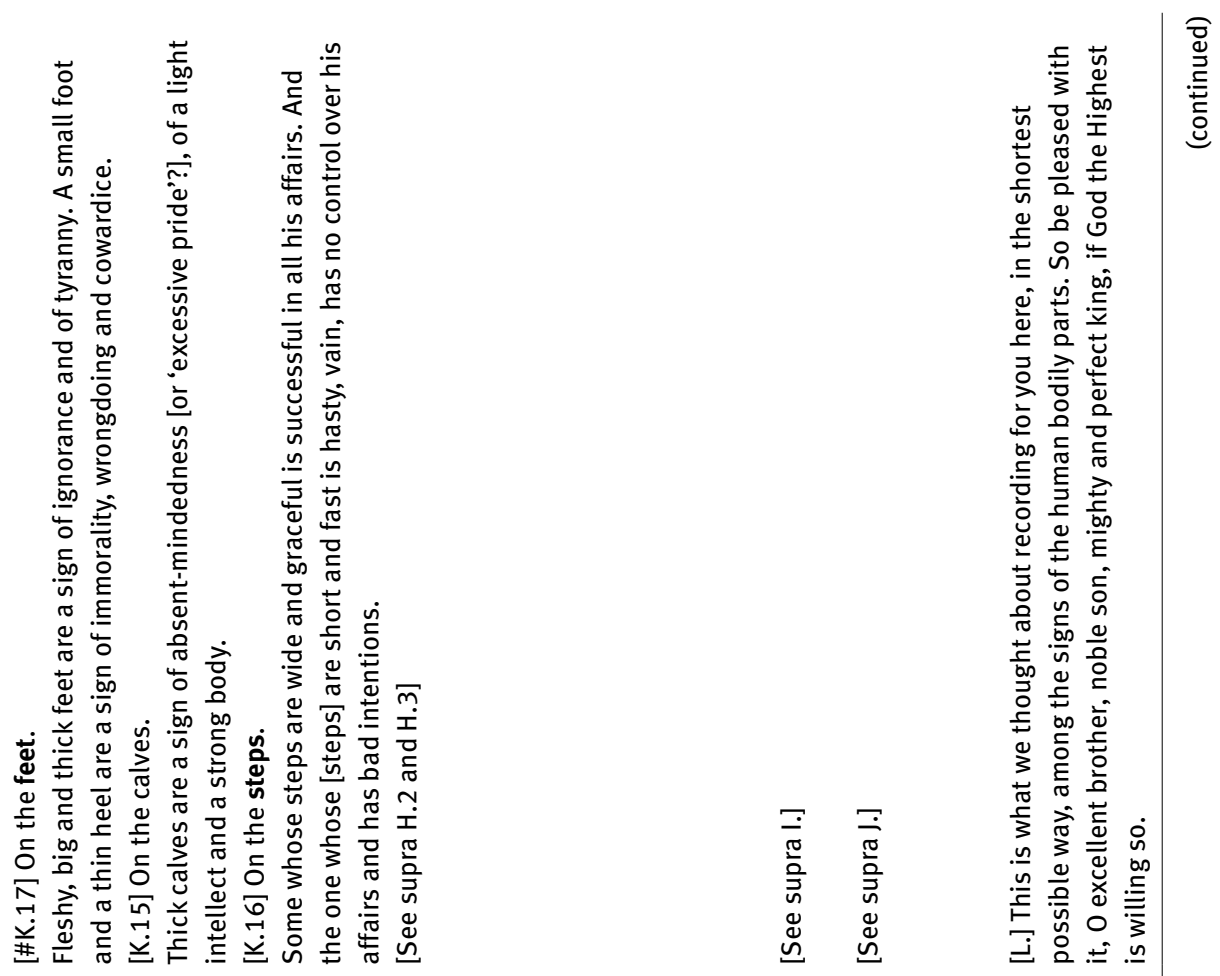

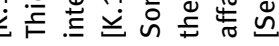

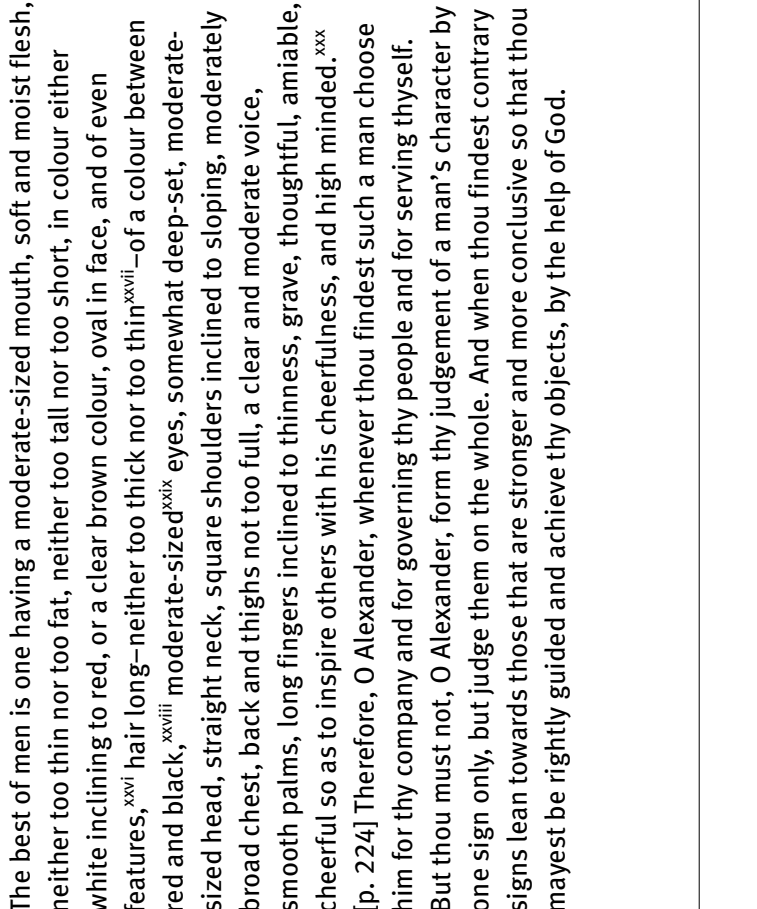




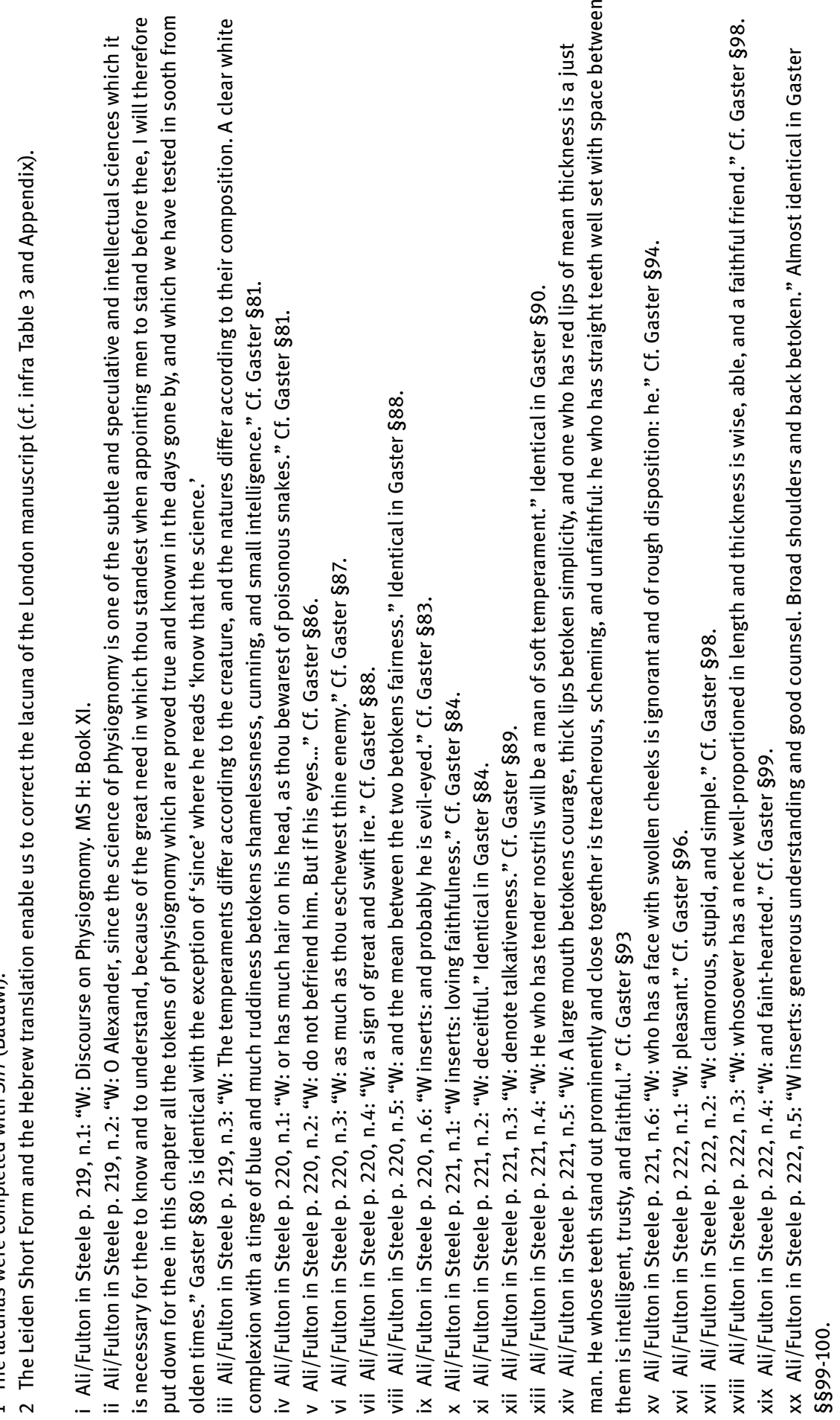




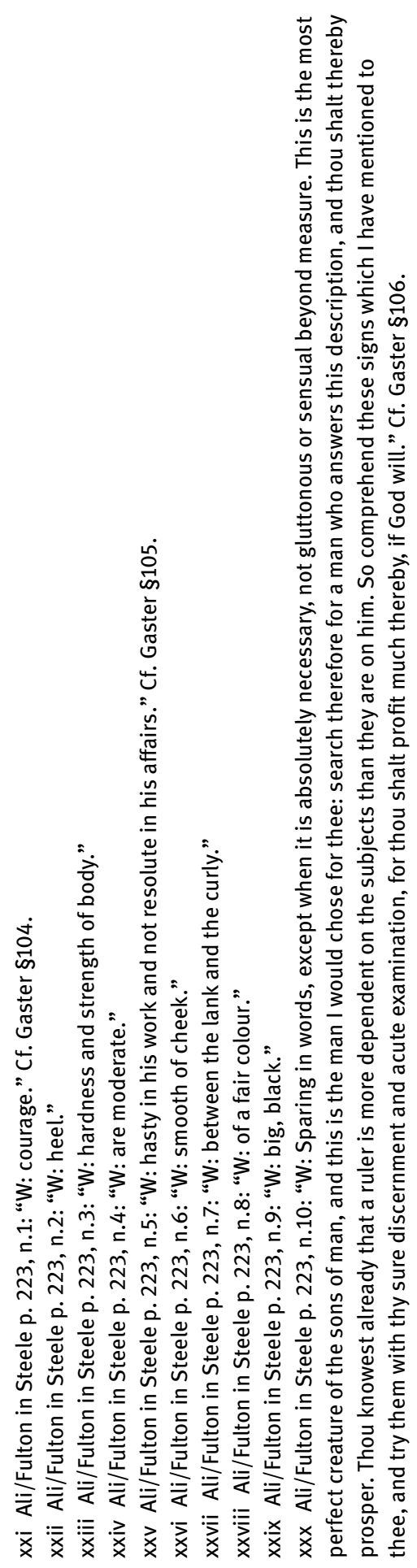




\section{The ideal portrait(s)}

While the London Physiognomy has only one ideal portrait (section [H.]), preceding the bodily signs, the Long Form offers two often contradictory portraits set up as enclosing the bodily characteristics (corresponding to London's [H.1] and [H.2-H.3] sections). In the London Physiognomy, the portrait of who could be taken for "friend" or "company" (London text, section [I.]; Sirr-Badawī, 118.13) is thus entirely given before the announcement of the detailed rules for each bodily part and a section ([J.]) on the number of signs that should be taken into account. ${ }^{124}$ In the Long Form, a second ideal portrait is given following the bodily characteristics, where "Aristotle" states that such a person would be the best company and administrator for "Alexander." 125

Affinities can be detected between London, the Short Form, and the ideal portraits at the end of Abū Bakr Rāzì's chapter on physiognomy in his Tỉbb al-Manșūrī (pp. 104-105) while in the Long Form, the bodily details seem to preserve more of Rāzì than does the Short Form. The comparison of our sample argues for a number of lost intermediaries between the Short and the Long Forms of the Sirr al-Asrār. The possible influence of a common source or a different version of Rāzī's text might also have been in play. The chapter on Physiognomy in Abū Bakr al-Rāzì's Tỉbb al-Manșūrī (Lat. Ad Mansorem) ends with a series of portraits in which a number of the positive or negative characteristics are assembled to depict a character. ${ }^{126}$ Rāzì’s interest for physiognomy is attested in a number of his works, and a section copied from his lost Description of women (Wașf al-nisā') shows him quoting Polemon. ${ }^{127}$ For Rāzì, physiognomy is part of medical knowledge and it appears as such in the Tibb al-Manșūri after a section on the four Galenic humors and their influence on characters. As

124 See the parallels in Abū Bakr al-Rāzī, al-Tỉbb al-Manșūrī, 107, where it appears at the very end of the chapter on physiognomy, after eight short portraits. Rāzī specifies that in the case of contradictory signs, precedence should be given to the face and the eyes. This point is missing from the Sirr versions. On the number of signs that should be taken into account, cf. Adamantius (A3), supra n. 120.

125 Cf. Sirr-Badawī, 124.1-4; Steele 1920, 224.

126 The "man of good understanding and composition," "the philosophically inclined," "the man of coarse manners," "the impudent man," "the bitter man," "the lustful man,” "women's characteristics and character," "the behaviour of eunuchs." Cf. Abū Bakr Rāzī, Tỉbb al-Manșūrī, 104-105. Another work of Abū Bakr al-Rāzī, the Spiritual Medicine (al-Tỉbb al-Rūhānī), which he dedicated to the same patron as the Tibb al-Manșūri, includes an ideal portrait of the virtuous man but is limited to ethics (see the translation by Arberry 1950, 102). The Tibb al-Rūhāni addresses the private behaviour and ethics of someone seeking virtue (defined as a way of moderation between two extremes, although in Rāzī, this doctrinal point cannot be limited to an Aristotelian influence). In his preface, Rāzī states that the Tibb al-Rūhanī was composed as a complement for the Tỉbb al-Manșūrī, where he addressed "corporal medicine (al-țibb al-jismānì)" and that he has composed a larger book on spiritual medicine, but without giving its title. We will return to the traces of Rāzī in the Sirr in the conclusion.

127 Cf. al-Shayzarī, Jamharat al-Islām dhāt al-Nathr wa-l-Nizāam, MS Leiden, Or. 287 (copied in 1300), fol. $146 \mathrm{v}$. 
much as with Rāzì's ideal bodily characteristics in the Tỉbb al-Rūḥ̄āin, the ideal man depicted by "Aristotle" for "Alexander" in the Sirr al-Asrār is an epitome of the Greek metriotēs, but the vocabulary used in Rāzi differs from that of the Sirr. ${ }^{128}$ Steele, after Förster, identified a number of parallels between the Tibb al-Manșūrī (which he used through a Latin medieval translation) and the Sirr but no reference is made there to the teachings as being those of Aristotle for Alexander. Differences in the vocabulary do not necessarily argue for two distinct sources and may be the result of geographical variations in the use of Arabic.

As could be seen with Table 1 supra, the ideal portrait in the London manuscript cannot simply be derived from the addition of the two portraits of the Long Form. If some elements of [H.1] can be found in the Long Form, they are scarce and not always literal (highlighted in the following table with italics, and if displaced, in bold and italics). For [H.2] and [H.3], more parallels can be found between them and the second and concluding portrait of the Physiognomy in Sirr-Badawi (see below for the comparison). Since the Arabic of Badawī and that of the London text can be compared in Table 1 supra, we will focus on the comparison of the translated texts (with parallel elements in italics, additions underlined and displaced elements in bold). Although a number of common elements can be found between the London Physiognomy and that of the Long Form, we will see in the next section that a comparison of the two different versions of the Short Form (the Berlin SF7 and the Leiden SF8) reveals an even higher number of parallels between the Long Form and the Short Form in seven chapters. ${ }^{129}$

The portrait, as it appears in the London text, can be divided into three main sections: (1) the stature and general appearance, (2) a succession of the best characteristics from head to trunk, followed by the voice and speech and (3) the hands and fingers, followed by a discussion of general humours and behaviour. Compared to the Short and Long Forms, the portrait thus seems shorter and may have been abbreviated from a longer model. Apart from the stylistic differences ("medium stature" versus "of middle-stature, neither tall nor short"; "head neither too large nor too small” versus “a middle-sized head, neither small or big”), the Long Form's first ideal portrait is based on a summary of what would have been the best of the bodily characteristics, although these characteristics follow. Some of these elements (about the 'hair,' the 'eyes' and the 'speech' and 'voice') are missing in the London text (see supra Table 1). In the Short Form however, the (single) ideal portrait concludes the text and follows the enumeration of the signs expressed by each bodily characteristic.

128 On the medical background of the theory, see Hoyland 2006, 318-319 and André 1981, 9-16. 129 See infra Appendix, the seven-book Short Form (SF7) agrees with the Long Form (as of Sirr-Badawī) in most of the additions it presents against SF8. 
A number of elements in the ideal portrait are reminiscent of the characteristics of the ideal vizier, which forms an important part of Book IV in both the Long and the Short Forms. ${ }^{130}$ An element which appears to be stemming from the ideal vizier's portrait and is common to the Sirr and the London Physiognomy is the straightness of limbs (or the warning against handicap). The Sirr gives a political flavour to the necessity for counsellors to have healthy limbs: “...counsel depends on the body; and when the body grows decrepit through age counsel also becomes weak" (Ali/ Fulton, in Steele, Secretum Secretorum, p. 233; cf. Sirr-Badawī, p. 134). The matter figures at the head of the fifteen qualities expected of a vizier: "His limbs should fulfil their functions perfectly" (Ali/Fulton, in Steele, Secretum Secretorum, p. 237; cf. Sirr-Badawī, p. 138). ${ }^{131}$ In both the London text and the Long Form according to Sirr-Badawī, the warning is repeated twice (London text: [E.] and [G.]; Sirr-Badawī: 118.3-4 and 118.8). The first warning is attached to a rejection of "blue-eyed blond [persons]," the source of which also appears to be the section on the best vizier, although the element is missing from the Long Form versions. ${ }^{132}$ In both texts, such a note might have found its way into the Physiognomy chapter by being added to the alchemical metaphor of the womb and the pot as a gloss. ${ }^{133}$ This process would explain most of the disparities witnessed between the two main versions of the Sirr al-Asrār. The language of the various witnesses in reference to "people born disabled" is different, and betrays a number of paleographical corruptions: London text, section [E.], "a war min aṣl al-khalqa" where a war but Sirr-Badawī, 118-3-4: "jarī' az ar," sc. "insolent and thin-haired," possibly resulting from a probable corrup-

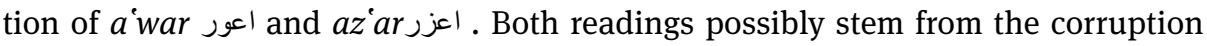
of "[with] prominent cheeks (awjan) and thin-haired" as in Leiden SF8 manuscript (fol. 107r13), corresponding to the Hebrew version (Gaster $§ 81 \mathrm{cf}$. infra Table 3 and Appendix).

Yet another portrait, that of the best sovereign, forms the subject of Book II (once the medical and pseudo-scientific tractates added to it in the version of the text represented in Sirr-Badawī are removed) ${ }^{134}$ but is not as systematical as the vizier's portrait. The title of Book II indicates that its focus is on the king's appearance or

130 Forster 2006, 26-27.

131 The Short Form, according to the Oxford manuscript, has a somewhat different form of the sentence: "He must be perfect in all his limbs, trained for the work for which and to which he is chosen” (Ali/Fulton in Steele, 1920, 238, n.1). On handicap in Islam and the influence of Greek medical theories, see Ghaly 2009, 68-72, referring to Polemon and to the Aristotelian tradition in Arabic.

132 Cf. Ali/Fulton in Steele 1920, 239, n. 8 and infra, Table 3).

133 See the paper by Regula Forster in this volume.

134 The tractates are usually localized outside of Book II in the Short Form witnesses (cf. Forster 2006, 25) as noticed by Manzalaloui 1974, 169-170. He further points (loc. cit., 208-210) to the strongly Platonic background of Books II and III when read according to the Short Form version. Steele had already stated the possible externality of the material added to Book II in the Long Form, cf. Steele, 1920, xxxix-xl. 
etiquette ("About the king and his appearance...," fī ḥâl al-malik wa-hay'atuhu). ${ }^{135}$ The reader is informed in terms reminiscent of the chapter on Physiognomy (cf. supra Table 1, sections [H.2] and [K.18]) that the king should have a melodious, eloquent and loud voice, though not speak much (Sirr-Badawī, p. 78; Ali/Fulton in Steele, p. 185), and laugh little (Sirr-Badawī, p. 80; Ali/Fulton in Steele, p. 187). Manzalaoui's analysis of the vizier's portrait and its parallel in the works of al-Fārābì confirms in his eyes the influence of Plato's Republic on the ideal model which formed the background of the sovereign and/or that of the good administrator according to the Sirr al-Asrār. ${ }^{136}$ Manzalaoui believed that both Fārābī - in whose Virtuous City a very similar portrait (that of the "imam-philosopher") appears - and the Sirr were under the influence of the Brethren of Purity, which he believed came first chronologically. ${ }^{137}$ Fārābī died some twenty-five years before the Short Form version of the Sirr was available to Ibn Juljul in Cordoba. He may have known the Sirr, for he knew other Pseudo-Aristotelian letters to Alexander. ${ }^{138}$ But Fārābì's familiarity with the translations realized within the Baghdadian circles and that of the Abbasid chancellery makes it necessary to allow for the possibility that he might have relied on similar sources, such as the ones used by the Brethren and the author(s) of the Sirr al-Asrār as we know it. Fārābī's contribution to political philosophy was achieved in a context where the search for a definition of the ideal sovereign - be he imam,

135 Or, according to the SF7 Sprenger 943, fol. 4v, "kingly etiquette (fì tadbīr al-malik)." Hāl is an extremely wide notion, meaning "state, position, condition" while tadbīr also carries a number of meanings, such as "management, self-government, results, regimen" and seems to me synonymous but somehow more elegant than hāal, which sounds slightly archaic or colloquial when applied to a king. On the variants of the chapter's titles in the tables of contents of the Short Form manuscripts, see Grignaschi 1976, 97-101.

136 See Manzalaoui 1974, 196-199; cf. Walzer 1985, 238-241 (on the necessary perfection of the limbs) and 246-249 (on the twelve required qualities of the ideal ruler according to Fārābī). The vizier's portrait thus seems adapted from Plato's philosopher-king, while the ideal sovereign depicted in Book II of the Sirr has other influences (Indian and Persian). Manzalaoui gave a full comparison of the different versions of the portrait with the parallels in Fārābi and the Epistles of the Brethren of Purity but Grignaschi 1976, 15-16, criticized his findings, poiting to the fact that the Sohag manuscript on which Manzalaoui relied was of inferior quality than the other witnesses of the Short Form.

137 On the dating of the Sirr al-Asrār and that of the Brethren of Purity, cf. Forster 2006, 18-19.

138 The De Mundo was certainly available at the Hamdanid court in Northern Syria, where Fārābi stayed during the last years of his life, for a translation from Syriac into Arabic was made there by 'Īsā b. Ibrāhīm al-Nafīsī, the physician of Sayf al-Dawla [r. 947-967]. It belonged, with other letters in which echoes and parallels to the Sirr al-Asrār can be detected, to the Pseudo-Aristotelian Epistolary Novel once assembled at the Umeyyad court in Syria under the authority of Sālim Abū al-'Alā', a secretary and physician of the caliph Hishām ibn 'Abd al-Malik [r. 724-743]. Fārābī quotes a letter of Aristotle to Olympias (lacking in the Pseudo-Aristotelian Epistolary Novel as we know it) in his Harmony between the Opinions of the Two Sages, Plato and Aristotle (Kitāb al-jam bayn ra'yay al-hakimayn Aflātūn al-ilāhī wa-Arisțūtālīs), of which a French translation by Abdel-Messih 1969, 305-358 (see 353) is easily accessible. 
caliph, or philosopher-king - was so common that the influence of Plato's Republic cannot be circumscribed to the well-defined milieu of Aristotelian or Neoplatonist philosophers. ${ }^{139}$ The fact that some of the detailed qualities of the imam-philosopher of Fārābī or that of the philosopher-king of Plato are ascribed to the vizier in the Sirr al-Asrār must be seen as part of the mistakes and oddities of a work in which material of diverse origins were often compiled unskilfully. ${ }^{140}$

The first portrait, as it appears in the physiognomy chapter in the Long Form, cannot be the source of the one we read in the London Physiognomy. Some of its additions are parallel to what will constitute the second portrait of the Long Form, coming as a conclusion to the bodily characteristics and the interpretation of the signs they betray. In the case of the second portrait, the impossibility of direct influence seems evident too. If some common elements could be found between the Long Form and the London text, missing intermediaries seem to be taken into account in order to explain the discrepancies. Some of the elements of the Long Form's first portrait, especially those on the voice and talkativeness, can be detected in the London text, section [H.2]. The second portrait of LF comes closer to the SF (unique) portrait and to a portrait "of the man of understanding and of good nature" according to Abū Bakr al-Rāzī than does the portrait of the London Physiognomy, where the echoes of SF are more important in the second part of [H.2] and very clear in [H.3]. The beginning of the LF second portrait and that of the unique portrait in SF is almost entirely parallel to Rāzì's portrait of the "man of understanding and good nature" although this part seems unknown to the source of the London Physiognomy. To suggest that Rāzì was used by the author(s) of the Sirr al-Asrār (the original author but also, possibly, a revisor making his own use of Rāzī) should certainly be seen as a hypothesis worth of investigation, but without analysing more manuscript witnesses, we cannot judge the question here. The matter is complicated, as will be seen in the conclusion, by the fact that Rāzī used Ibn al-Biṭrīq's translations in his works.

Another element, best exemplified by a comparison of the Leiden SF8 with the Berlin Sprenger SF7 texts, is the role of revisors and copyists in the way the vocabulary was adapted and understood. Thus, the omission of an adjective in a series of

139 Daiber 1986, 6, for the parallels to and echoes of the Republic in the works of Fārābī.

140 See in particular the remarks of Manzalaoui 1974, 180-181, and Grignaschi 1976, 20-22, on the emanationist scheme of the Sirr.

141 Missing in Regula Forster's translation (supra in this volume) because of the absence of an exact parallel to Abū Bakr al-Rāzì's bodily characteristics. It echoes, nevertheless, his portrait of the "man of good understanding and disposition (al-rajul al-jayyid al-fahm wa-l-țab)" (al-Ṭibb al-Manșūrī, 104-105 Șiddīqī). 142 Ali/Fulton's translation interprets the sentence somewhat differently, with "proportioned" for muwāfaqa, which I have translated "appropriate."

143 The phrase "pale but permeated with light red or brown" appears in both the portrait of the "man of good understanding" and in that of the "philosopher" in Rāzì, al-Ṭibb al-Manșūin, 105 Șiddīqī. Both portraits also include the characteristics of middle-size and medium waist, but use a different vocabulary. 
synonyms will result in a possibly different interpretation of the remaining words. The succession of two synonyms could be the result of a "double-translation"144" but it may also be seen as an example of hendiadys. However, once a synonym was seen as redundant by a copyist and omitted, a shift in the meaning of the sentence would occur that is difficult for us to distinguish from a paleographic mistake. The role of copyists and revisors could thus be all the more effective when small details were added or omitted to adapt the ideal portrait(s) and make it fit a patron or a pretender to the position. This "common-sense" or "practical factor" bears a great deal of weight in any attempt to construct a stemma.

The Arabic wording in the last sentence of [H.3] is almost identical (the addition in LF, here underlined, is possibly the result of a double-translation or that of the choice by the translator of resorting to a hendiadys). We read in the London text:

$$
\text { ويكون بسيط الكفّين طويل الأصابع مائلاً إلى الدقّة ويكون مع ذلك قليل الضحك والمزاح كأنّما يخالط نظره فرح }
$$

And in the Long Form (according to Sirr-Badawī, 123.10-11):

سبط الكف، طويل الأصابع مائلة إلى الرقة قليل الضحك و المز اح و المر اء، كأنما يخالط نظره سروره أو فرح .... The first element, about the hands or palms (kaff has both meanings in Arabic), is italized to indicate a possible paleographic corruption: basit, in the London text, usually means 'large,' while sabit is said of 'well-built [hands]' and has the metaphorical meaning of open-handed when used about a 'hand.' Most of the elements in the London Physiognomy can be found in the Short Form portrait, apart from the additions at the beginning of [H.2]. Moreover, the Short Form has a single portrait, as opposed to the two divided portraits of the Long Form. In the Short Form, the portrait concludes the section, while in the London text, it precedes the enumeration of the bodily characteristics (as does the first portrait of the Long Form). For Grignaschi, the differences in the three versions of the Physiognomy represented by the Sirr's two versions and the London manuscript could be explained by the possibility that the Kitāb al-Qānūn refered to in the first lines of the London Physiognomy might have been a complete text composed of several medical or pseudo-scientific sections which were entirely integrated to a preceding version of the Sirr al-Asrār. ${ }^{145}$ Grignaschi's hypothesis is worth investigating and could possibly explain why the comparison of the texts tends to show that, if indeed a common source should be assumed, the London text seems to have diverged at an early stage and should not be seen as a direct ancestor of either the Short or the Long Form. ${ }^{146}$

144 Double-translations were common in the process of revising texts. The addition of a synonym might also be the result of the insertion within the text of a marginal note in which a reader clarified the meaning of a word by adding a synonym that was more familiar to him (or to his location and epoch).

145 Grignaschi 1976, 44-46.

146 As was also assumed by Manzalaoui 1974, 183-184. 
The Two portraits.

Long Form's first portrait [Steele, p. 220] ${ }^{141}$

The best proportioned construction is of him who possesses medium stature, black hair and eves-the latter somewhat deep set-round face, white mixed with red or moderately brown colour, with perfect form and well proportioned body, head neither too large nor too small. Who speaks little except on necessary occasions, a voice neither too loud nor too low, inclining towards thinness but not too thin. And whose temperament inclines towards spleen and bile.
London Physiognomy

[H.1.] 0 Alexander! Know that the best and most appropriate ${ }^{142}$ person I wish vou as a friend is a man of middle-stature, neither tall nor short, with a medium waist, neither too thick nor too slender, who has a middle-sized head, neither small or big, showing a good countenance and a beautiful appearance and face, meaning that [his face] should be between round and fleshy, pale but permeated with light red or brown. ${ }^{143}$
Long Form's second portrait [Ali/

Fulton in Steele, p. 223-224]

The best of men is

one having a moderate-sized mouth,

soft and moist flesh, neither too thin nor too fat,

neither too tall nor too short, in colour either white inclining to red, or a clear brown colour,

oval in face, and of even features, hair long-neither too thick nor too thin-of a colour between red and black

moderate-sized eyes, somewhat deep-set, moderatesized head, straight neck,

square shoulders inclined to sloping, moderately broad chest, back and thighs not too full,

a clear and moderate voice,

smooth palms, long fingers inclined to thinness,
The best man is

the balanced man, understanding and of good nature; his flesh should be soft, moist, in the middle between thin and coarse,

neither tall nor short, white, with a tendency towards red and brown, of pure brown, with smooth cheeks, of an easy face, with beautifully arched eye-brows, with beautiful hair, neither lank nor smooth nor curly, of reddish hair, of medium-sized eyes, tending to be deep, of a

medium head, of a straight neck, his shoulders tending to meet each other, without flesh in the backbone and on the hips, with a balanced voice, neither thin nor coarse,

of open hand, with long fingers tending to be thin,
[H.2.] [And he must havel reasonably long hair, neither too flat or too curly, neither too thick or fine, between black and blond [or 'chestnut'], that is, red-brown. And he must have big eves, tending slightly to hollowness, between black and blue, that is deep-blue. [His] neck should be neither [too] long or [too] short, and neither fat nor slender, but regular.

And with this, he should have bending shoulders and his loins and hips should not be too fleshy.

His voice should be clear, balanced between being pleasant and soft. In addition to this, he should not speak much, except when it is needed.

[H.3.] His hands should be large, with lank fingers, tending to thinness. And he should not 
grave, thoughtful, amiable, cheerful so as to inspire others with his cheerfulness, and high minded. laughing, joking and disputing little, so that rather his look is merging with his joy and happiness. (...) laugh or joke too much so that his gaze would reveal joy and happiness.

Comparison with the portrait in the Short Form (SF8).

Leiden, Or. 749, foll. 106v5-16

And the moderate [person], understanding and of good nature is the one whose flesh is soft and tender, neither too thin or too thick. He should be neither short nor tall, [of] fair [complexion] tending to red or yellow, with a pleasant face, long-haired, [but that his hair would be] neither too flat or too curly. Dark blond hair, of a medium range, [having] big eyes [of a colour] tending to dark or black.

The head of medium size, with a straight neck,

the shoulders a little bent, his back and thighs not too corpulent.

[And he should have] a clear and gentle voice, moderate between strength and softness, lank palms with long fingers, almost slender. He should not speak or laugh much and do it only when necessary.

His temperament should be inclined to melancholy and sanguinity, and his gaze should also be between contentment and happiness.
London Physiognomy

[H.1.] O Alexander! Know that the best and most appropriate person I wish you as a friend is a man of middle-stature,

neither tall nor short, with a medium waist ${ }^{147}$, neither too thick nor too slender,

Who has a middle-sized head, neither small or big, showing a good countenance and $\boldsymbol{a}$ beautiful appearance and face, meaning that [his face] should be between round and fleshy, pale but permeated with light red or brown.

[H.2.] [And he must have] reasonably long hair, neither too flat or too curly, neither too thick or fine, between black and blond, that is, red-brown. And he must have big eyes, tending slightly to hollowness, between black and blue, that is deepblue. [His] neck should be neither [too] long or [too] short, and neither fat nor slender, but regular.

And with this, he should have bending shoulders and his loins and hips should not be too fleshy.

His voice should be clear, balanced between being pleasant and soft. In addition to this, he should not speak much, except when it is needed.

[H.3.] His hands should be large, with lank fingers, tending to thinness. And he should not laugh or joke too much so that his gaze would reveal joy and happiness.

147 The Leiden MS has “an yakūn laḥmuhu layyinan,” possibly seen as too archaic a wording for someone's corpulence. This use of lahm ("flesh") to designate corpulence is common to the Short and Long Form, and to Abū Bakr al-Rāzī 
The comparison with Abū Bakr al-Rāzì's portraits of the "man of understanding and of good manners" and that of the "philosopher" reveal a large number of parallels between him and the two main versions of the Sirr, albeit the vocabulary used by Rāzi differs in several cases. The different vocabulary used by Rāzī would point to a common source rather than to either the direct influence of the Sirr al-Asrār on him, that of the Qānūn (if we accept Grignaschi's theory) or alternatively the use of Rāzì (d. 923 or 933) by the author(s) of the Sirr al-Asrār. ${ }^{148}$ Of interest is the fact that Rāzì seems to have coalesced two portraits together (indicated in the translation with the numbers in brackets).

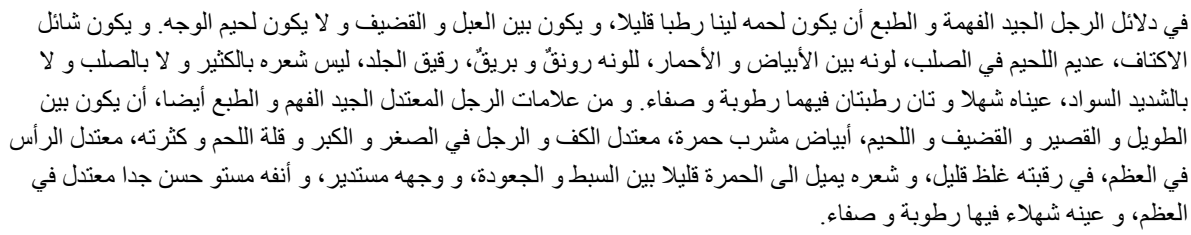

[1] On the signs of the man of good understanding and character, that his flesh [sc. "corpulence"?)] should be slightly soft and fresh, his face neither too chubby or too narrow, and not fleshy. And that his shoulders be large but without fleshy loins. His complexion should be between pale and reddish, but be bright and resplendent. His skin should be thin and he should not be too hairy nor should he have hairy loins or that his hair would be too dark. His eyes should be dark-blue and deep-set, wet with moist and purity. [2] And among the signs of a moderate man of good understanding and character also, that he would be neither too tall or too short, neither too slim or too corpulent, pale but permeated with red. With medium-size hands ( $k a f f$ ) and legs, that should be of reasonable corpulence, neither slender nor fleshy, of medium-sized head, with a slightly thick neck, his hair slightly tending to redness [sc. "brown"?], [half-way] between lank and curly, a round face, a straight nose, very elegant and of harmonious proportions, his eyes dark-blue, with moist and purity in them.

The comparison of Rāzī's portrait of "the man of good understanding” with the second portrait in the Long Form reveals a close affinity. Some mistakes in the LF texts can be corrected with the help of Rāzì: thus, the erroneous "the best of men is one having a moderate-sized mouth" at the very beginning of the portrait shows the paleographic corruption of fahm فه into fam ف فم (the correct version is the one we read in Sirr-Badawī, who relied here on better manuscripts than Ali/Fulton). Following it shortly, another element about "large shoulders" (shä'il al-aktāf) seems a preferable reading than "bending shoulders” ( $m a \bar{a}$ il al-aktāf), which is also the result of the paleographic corruption of شائل into مائل The first reading is confirmed by the SF7 version (see infra Table 3 and Appendix).

The second positive portrait in Rāzì's chapter on physiognomy in his Tibb al-Manșūri is that of the "philosopher (al-rajul al-faylasuf)," i.e. of the man loving wisdom, according to a Greek etymology which was certainly known to Rāzī.

148 Manzalaoui 1974, 227, considers the possibility that Rāzī used the Sirr al-Asrār directly or had for his Physiognomy section a source common to the one used in the Sirr. 


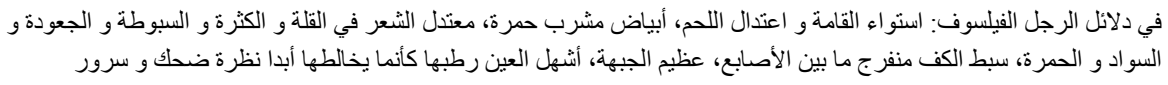

Among the signs of the man loving wisdom: a straight stature and a moderate corpulence [lit. "flesh"], pale [of complexion] tending to reddish, halfway between [having] scarce hair and a full head of hair, [and that those be] between lank and curly, between dark and red, with well-built hands ( $k a f f$ ) and clear separation of the fingers, a large forehead, dark-blue eyes the moist of which betrays constant mixture of laughter and happiness in his reflection (nazra).

In the portrait of the philosopher, Rāzī seems to be influenced by an Eastern (Buddhist?) model rather than a Greek one. ${ }^{149}$ Of special interest for the comparison of the different versions is his last point, on the merry gaze of philosophers, which is paralleled only in the Short Form versions of the portrait (see infra Table 3 and Appendix). The Long Form and the London Physiognomy seem to be more familiar with unhappy philosophers, unless they are under the influence of elements given in Book II and Book IV about the behaviours expected from sovereigns and viziers.

\section{Table 3: The Short Form Physiognomy}

We will now turn to a sample of the witnesses for the Short Form versions in order to verify their possible proximity to the London Physiognomy, but setting aside for the moment the complicated case of the portrait (where the "practical factor" of human interest may have been in play). The Sod ha-Sodot, a Hebrew medieval translation of the Short Formin eight books, was made in thelate 13th-or theearly 14th-century. ${ }^{150} \mathrm{As}$ Spitzer discovered, the Hebrew text may at times contain additions or glosses known only from the Long Form manuscripts or, for a number of sections, from the Sohag manuscript (an SF8 as well) discovered by Manzalaoui. ${ }^{151}$ If more parallels in the variants could be traced to the Long Form, we would be in a similar situation to what we saw in the London physiognomy where some of the variant readings and stylistic adjustements are parallel to those in the Long Form versus the Short Form.

Next to the Hebrew medieval version in Gaster's English translation, two Arabic Short Form versions of the Physiognomy chapter are provided with a translation (infra

149 Rāzī is well-known for his use of a wide range of medical sources. See Kahl 2015, esp. 14-28 and 71-159. 150 The mistaken attribution to Judah al-Ḥarizī (fl. early 13th-c.) stems, according to Spitzer, "The Hebrew Translations," p. 35, from the presence of his translation of Ḥunayn ibn Isḥāq's Ādāb al-falāsifa in the same Vatican manuscript as the Sod ha-Sodot (Vatican, Or. 53). It is unclear to Spitzer whether the translation might have been realized in Spain, Italy or Provence.

151 Spitzer 1982, 43-45. The Hebrew version edited by Gaster is an SF8, according to its own table of contents (§7, in Gaster 1908a, 116). The table of contents (Gaster, loc. cit., §7, p. 116) announces eight books but the "gates" of book eight ("On Occult sciences"), are numbered continuously in Gaster, resulting in the thirteen "books" of his translation, although Gaster noticed some discrepancies in the manuscripts he used (cf. Gaster 1908b, 1075-1076). 
Table 3): MS Leiden Or. 749 (an SF8) and MS Berlin, Sprenger 943 (an SF7). The Arabic text follows in an Appendix where I have used the Leiden manuscript as a base text, because of the relations noted between it and the Oxford manuscript Or. Laud. 210 (as witnessed from the footnotes to Ali/Fulton translation, see supra Table 2). In the annotation to the Leiden Arabic text, I gave the variants of the Berlin Sprenger text. A long lacuna in the Leiden manuscript (see the blank sections in Table 3) can be read in the translation according to the Berlin Sprenger manuscript (see infra Table 3), but as to the Arabic text, I have not deemed it necessary to give it in full since the manuscript is freely available on the website of the Berlin Staatsbibliothek. ${ }^{152}$

The Leiden manuscript is undated but some indications show that it is certainly later than the Hebrew translation. The Leiden manuscript (MS Leiden, Or. 749, foll. $76 \mathrm{v}-111 \mathrm{~b}$ ) was considered by Grignaschi as a good copy, and our own study of the text reveals that even if it is not free from mistakes and lacunae, it seems to preserve an early version of the text that included difficult expressions which later copyists usually left out. ${ }^{153}$ The manuscript is presumably not as old as Grignachi believed. ${ }^{154}$ It betrays a late Maghribi hand, using non-maghribi shapes for the letters $f \vec{a}$ ' and $q a f$, and was possibly copied at the request of Levinus Warner (d. 1665) during the time he spent in the Ottoman Empire. The texts preserved in the manuscript were copied on types of European paper common in the Warner collection and the quires are irregular. ${ }^{155}$ In Book III, "On the Representation of Justice (fi șürat al- 'adl)” (foll. 88r-89v), the drawing of the "Octagon" or "Circle" of Justice, a representation of a poem in eight verses forming the essence of Justice in an octagon (made of two visible squares and inscribed in a circle, as in the Leiden manuscript) or in a circle (as in the Berlin manuscript), was inserted from a separate folio (the stub is visible on fol. 90r) and pasted on the verso of fol. 89. As the hand and the ink of the drawing differ from that of the rest of the texts preserved in the Leiden manuscript, it seems that the

$152 \mathrm{http} / /$ digital.staatsbibliothek-berlin.de/werkansicht?PPN=PPN889280428\&PHYSID=PHYS_0003.

153 Grignaschi 1976, 15. Forster used the Leiden manuscript for her comparison of Johannes Hispalensis' text with the Arabic versions, cf. Forster 2006, 250-283. A description of the manuscript is given by Badawī, Sirr al-Asrār, 64-66.

154 See supra, fn. 58. The contents of the manuscripts (two works are copied in addition to the Sirr al-Asrār) are mentioned by Forster 2006, 41, n. 198 and in Witkam 2007 (http://www.islamicmanuscripts.info/inventories/leiden/or01000.pdf).

155 Watermarked papers were used in the composition of the quires. Letters $\mathrm{W}$ and $\mathrm{E}$ appear in the first quires while the quires on which the Sirr al-Asrār are copied carry a watermark showing letters B and $\mathrm{G}$ separated with an upper flower in-between (fols. $73,80,88,90,95,96,101)$. The quires are not following standard rules: in majority of seven-sheet (the $2 \mathrm{nd}, 4 \mathrm{th}, 6 \mathrm{th}, 8 \mathrm{th}$ and 11 th quires are septinions) intersperced with ternions (1st, 5 th and 7 th quires), quarternions (3rd and 10th quires) and quinions (9th quire) with more irregularities in the part where the Sirr al-Asrār is copied (fols. 76r-110r). The final 12th quire is a binion. A full study of the text would be needed to detect if the irregularities correspond to lacunae in the text. 
drawing was taken from another manuscript and pasted in. Possibly as a result of this insertion, the Leiden manuscript does not have a title of any kind for Book IV, the text of which starts directly on the recto of folio 90r, which is facing the drawing. ${ }^{156}$ At the end of Book IV, the title of Book V (starting on fol. 93r), "On the ambassadors and messengers", is highlighted with red ink, and so are the titles of Book VI (93v: "On the government [siyāsa] of his [army] chiefs and horsemen [al-asāwir] ${ }^{157}$ among his soldiers"); Book VII (95r: "On the conduct [siyāsa] of wars") and Book VIII (103r: "On Special sciences and revealed secrets [asrār nāmūsiyya]). ${ }^{158}$ Other sections (such as the addresses "O Alexander!") and the sub-chapters or "gates" are highlighted with red ink as well. Some interpolated material can be detected in the Leiden manuscript, as was already noted by Badawī and Forster. ${ }^{159}$

As to the Sprenger manuscript (MS Berlin Sprenger, Or. 943, fols. 1r-22v), where only the Sirr al-Asrār is copied (on fols. 22v, 1-3), the colophon suggests that it is a copy of a model whose copyist was the otherwise unknown Ibrāhīm b. Yaḥyā b. Qāsim b. Aḥmad b. al-Mahdī b. Yaḥyā b. Manșūr b. Yaḥyā b. Manșūr b. al-Mufaḍ̣al al-Hādī. If genuine, the name points to a possible Zaydite origin. ${ }^{160}$ The actual copyist's name might have been preserved at the end of the book, but the Berlin codex has a lacuna, ending with the first lines of a treatise titled Book of the Selected invocations and Experienced remedies (Kitāb al-ad 'iya al-muntakhaba wa-l-adwiyya al-mujarraba) ascribed to a certain al-Bisțāmī. ${ }^{161}$ The Sprenger manuscript was used for comparative purposes by Grignaschi, who noticed in it parallels with elements he found solely in the Long Form and in what he regarded as one of the sources of the Sirr al-Asrār - the Umayyad Book

156 The quire is nevertheless composed of eight bifolia (a quarternion), and the folio on which the drawing was pasted (fol. 89v) was left blank and so is half the recto of fol. 89. Did the copyist initially plan that a smaller drawing would be executed there? Alternately, the missing title of Book IV might have been copied on the same bifolio as the lacuna witnessed in the text (see infra Table 3), which corresponds to a part of the bodily characteristics in the Physiognomy. The Leiden MS offers a number of variants in the eight verses of the Octagon, the most important of which is certainly its replacing the term "king (malik)" by "imam (imām)" but these cannot be fully discussed here (the geometry of the drawing reproduced in Sirr-Badawi, p. 127 is not faithful to the original).

157 See Lane, Dictionary, vol. IV, p. 1465.

158 Thus, Leiden Book V = Sirr-Badawī (p. 145) Book VI while Leiden Book VI = Sirr-Badawī (p. 147) Book VIII. Sirr-Badawī Book V (p. 144) and Book VII (p. 146) appear as "gates" in the Leiden manuscript within Book VII ("on Wars") directly following the portrait of the ideal vizier. On nāmūs rendering "secret" or "revelation" see Lane, Dictionary, vol. VIII, p. 2854.

159 Cf. Badawī, Sirr al-Asrār, 156, n.1; Forster 2006, 29, n. 121 and 97, n. 590. Another truncated citation for which no parallel in Sirr-Badawī can be found appears on MS Leiden Or. 749, fol. 99r, shortly before a short paragraph paralleled in the London Physiognomy (section [I.]) and in LF, within the section on the portrait of the ideal vizier in Book IV (Sirr-Badawi, 118.13).

160 According to Ahlwardt's catalogue $\left(\mathrm{n}^{\circ} 5603\right)$, the manuscript would be from the $16^{\text {th }} \mathrm{c}$. The collection of Aloys Sprenger (d. 1893) was offered for the library of the King of Prussia in 1857.

161 The title, as well as the Sufi overtones of theses lines, point to the ninth-century Abū Yazid Bisțāmī as the putative author. 
of General Politics (Kitāb al-Siyāsa al-'Ammiyya), which like the Sirr circulated as a letter purportedly written by Aristote for his disciple Alexander. ${ }^{162}$ Our comparison of the Physiognomy chapters in the Sprenger text and in the Leiden manuscript (infra Table 3 and Appendix) confirms the value of the Berlin manuscript. In the Berlin text (an SF7), what constituted Book VII of the Leiden manuscript is inserted within Book VI, the title of which encompasses the topics of Leiden Book VI and Book VII. The final book (Book VII of the Berlin MS and Book VIII of the Leiden MS) is entitled ("On Special sciences and revealed secrets...") in the table of contents of both but the title given within the text of the Berlin manuscript (fol. 18r) is simply "Book VII on medicine (al-maqāla al-sābi" $a$ fi $a$ l-tibb)." ${ }^{163}$ As to the date of this recension, the Short Form in seven-books already existed in the year 432 of the Hegira ( $=1030 \mathrm{CE}$ ) according to two manuscripts, one of them (the Charfet MS in Lebanon) ${ }^{164}$ stating explicitly that it is a copy of a model giving this date while the other one (Vienna 1828/Neue Folge 278) only has a note providing this date, without any specific details on the source of the information. ${ }^{165}$

The comparison of LF with the Short Form versions shows that the Berlin SF7 often preserves variants parallel to those of LF (as per Sirr-Badawī) against the Leiden SF8 while the London text would seem to stand between the two versions (cf. Table 3). ${ }^{166}$ In several cases, these variants concern two adjectives in the Leiden text that are reduced to one in the Berlin SF7 or inversely, one adjective in the Leiden

162 Grignaschi 1976, 24. Another parallel between an SF7 and the Siyāsa al- Ammiyya, this time missing from LF, was noted by Manzalaoui 1974, 175. Grignaschi probably took advantage of the Latin translation of the Sprenger Physiognomy chapter by Förster 1893, 183-222.

163 On the differences in the organization of LF and SF, see Forster 2006, 30. For a comparison of the contents of the last book in the different LF and SF manuscripts, including the Leiden and the Berlin Sprenger manuscript, see Forster 2006, 28-29.

164 Cf. Forster 2006, 13, n. 18 and 16, n. 58, referring to Armalet' catalogue of the Charfet library, 267, $\mathrm{n}^{\circ} 17 / 3,2$.

165 Manzalaoui 1974, 148 gives the following information about the Vienna manuscript: if was once part of the belongings of the Shihabiyya Library (in 17th-18th c. Lebanon; members of the Shihabi dynasty converted over time and Druze, Sunnis and Christians alike would be found among the members of the court); the manuscript was in Venice in 1542; reader's notes in Syriac script were made in 1362. Badawī, Sirr al-Asrār, 69-71 deciphers the reader's marks and states that about one third of the text is missing, but it is unclear whether these lacunae are parts of the SF7 text or in comparison to LF. Needless to say, further study of the two manuscripts will be needed before the dates and the relation between the manuscripts can be accepted with any certainty.

166 Manzalaoui 1974, 222-224 shows that the London text is an intermediate version. On SF7, Manzalaoui 1974, 174-175, remarked that it seems later than SF8 (apart from one SF7 branch and the Hebrew tradition, which should be earlier) and attempted to correct some of its readings. Steele believed judging from the Oxford SF7 - that the main difference between SF7 and SF8 was the concatenation of Books VI and Books VII into one, Steele 1920, xiv-xv. But he himself adds (loc. cit., 242, n.1) that parts of Book V according to the Gotha 1869 (an LF) manuscript used for the translation of Ali/Fulton are in fact thought to belong to Book IV in the Oxford manuscript while the last section of the same Oxford Book IV belongs in the Gotha manuscript translated by Ali/Fulton to Book VII (loc. cit., lvii, section $\mathrm{H})$. 


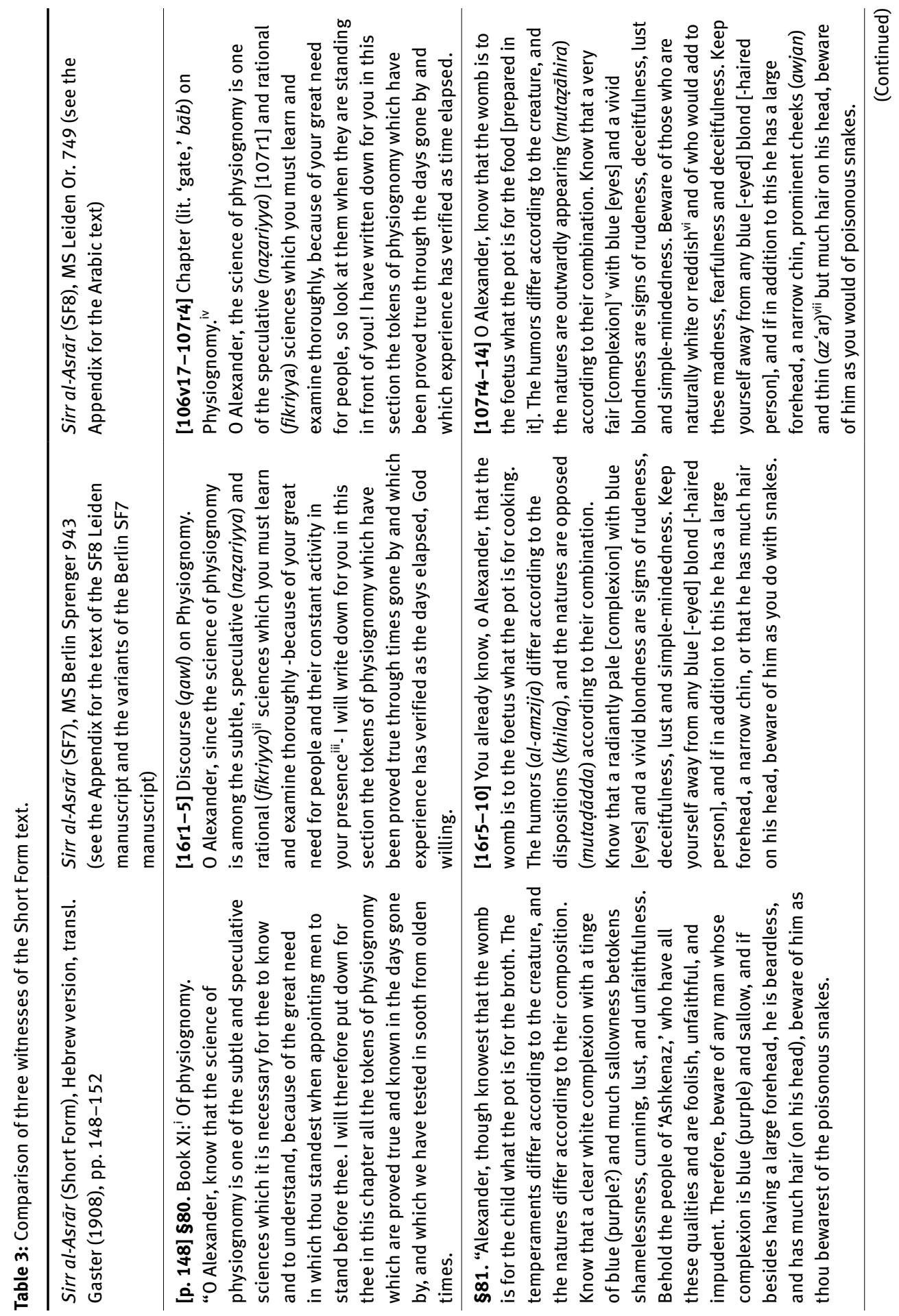




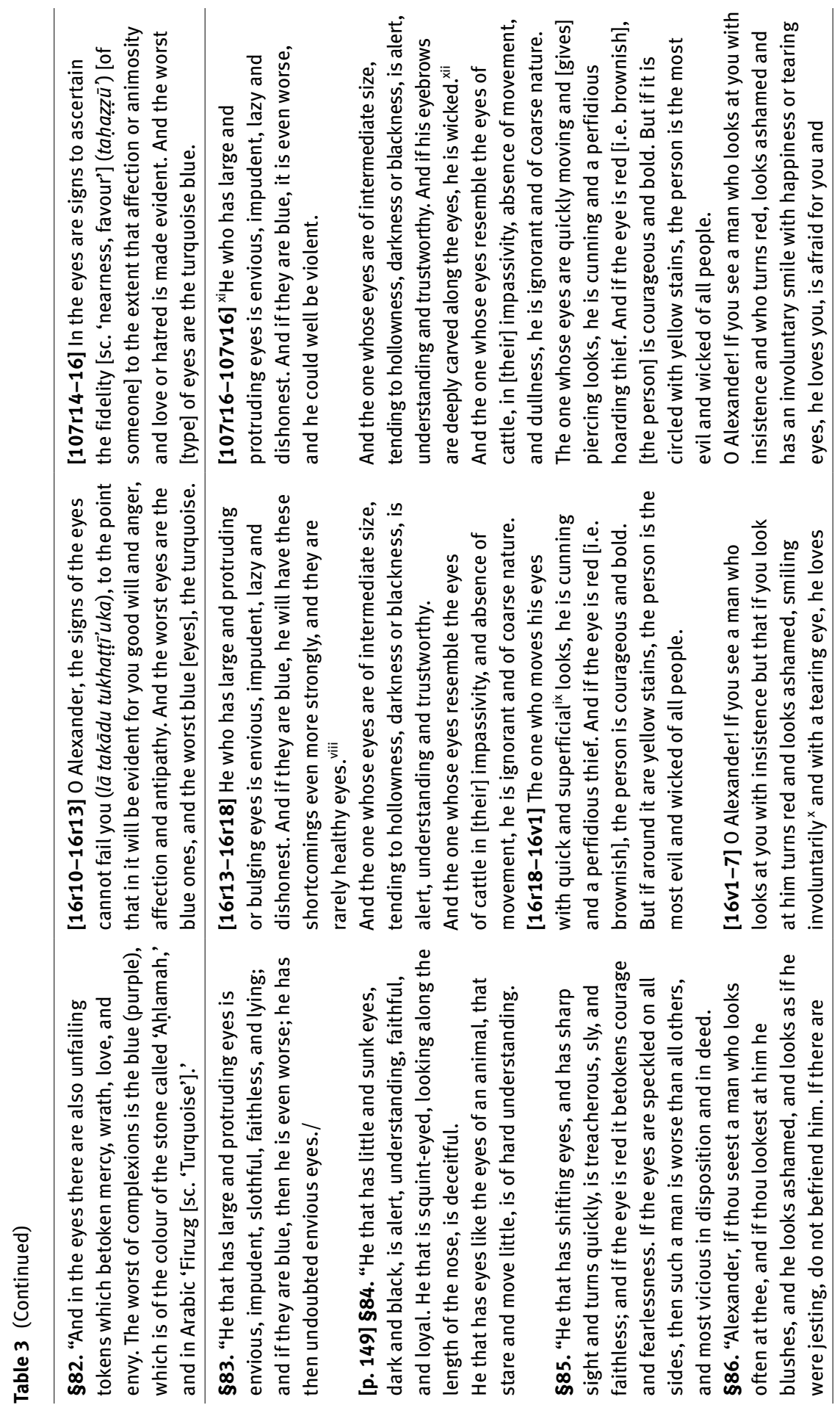




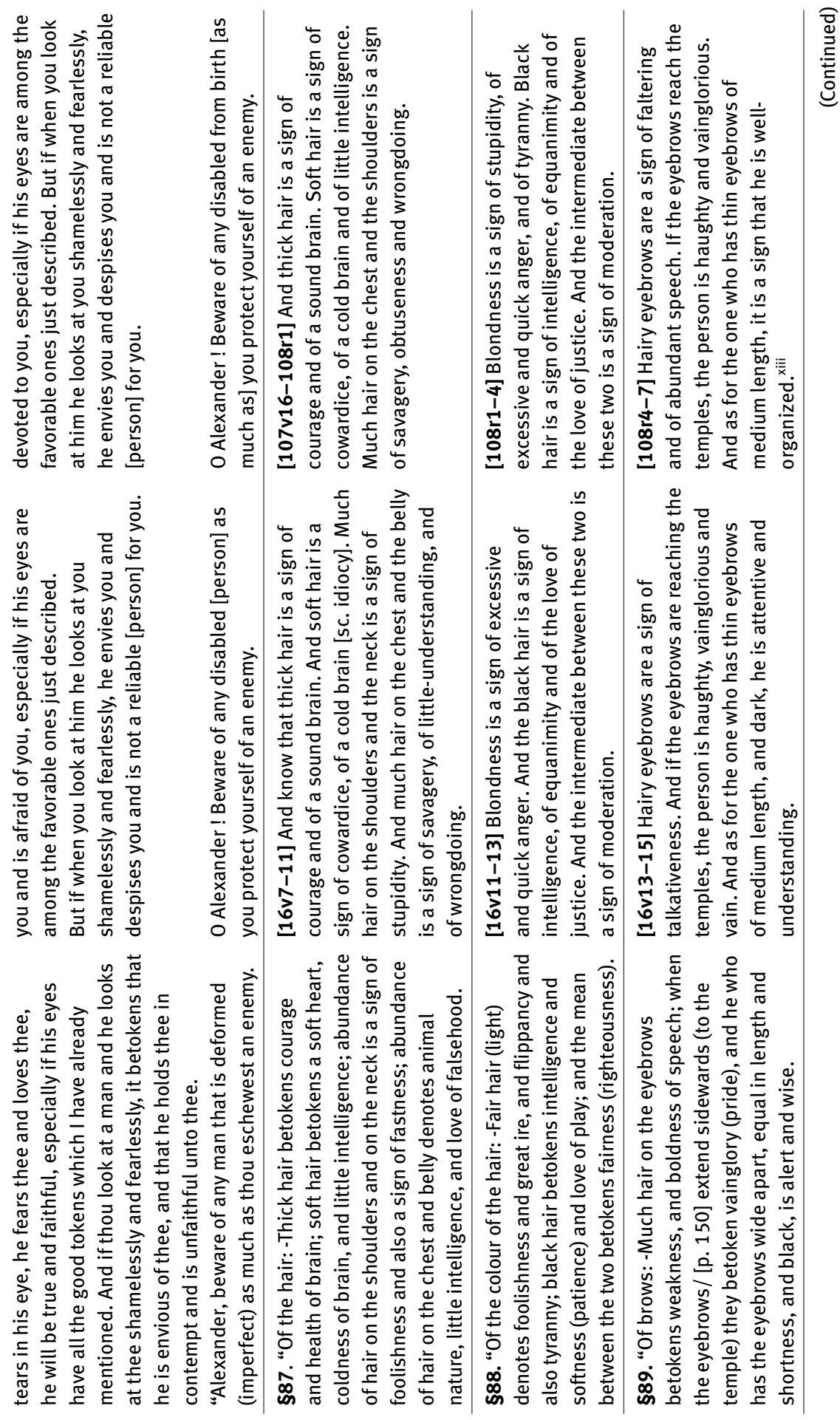




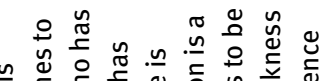

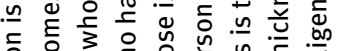

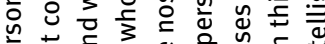
むั:

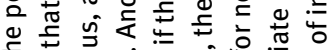

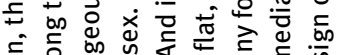
. 흐

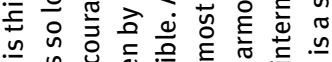

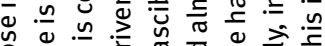

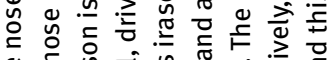

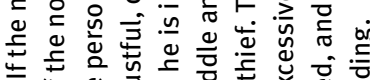

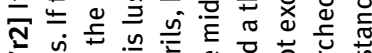

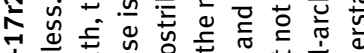

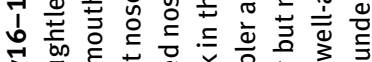

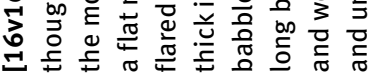

包

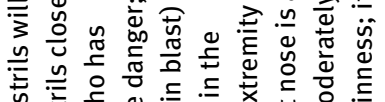

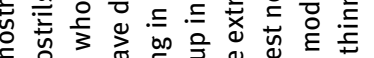

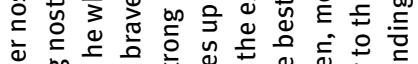

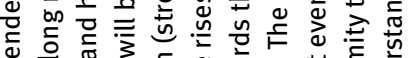
ज व

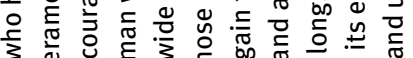
ब

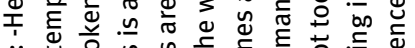

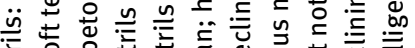
认ั

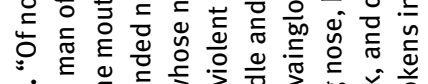

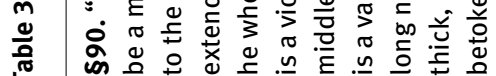

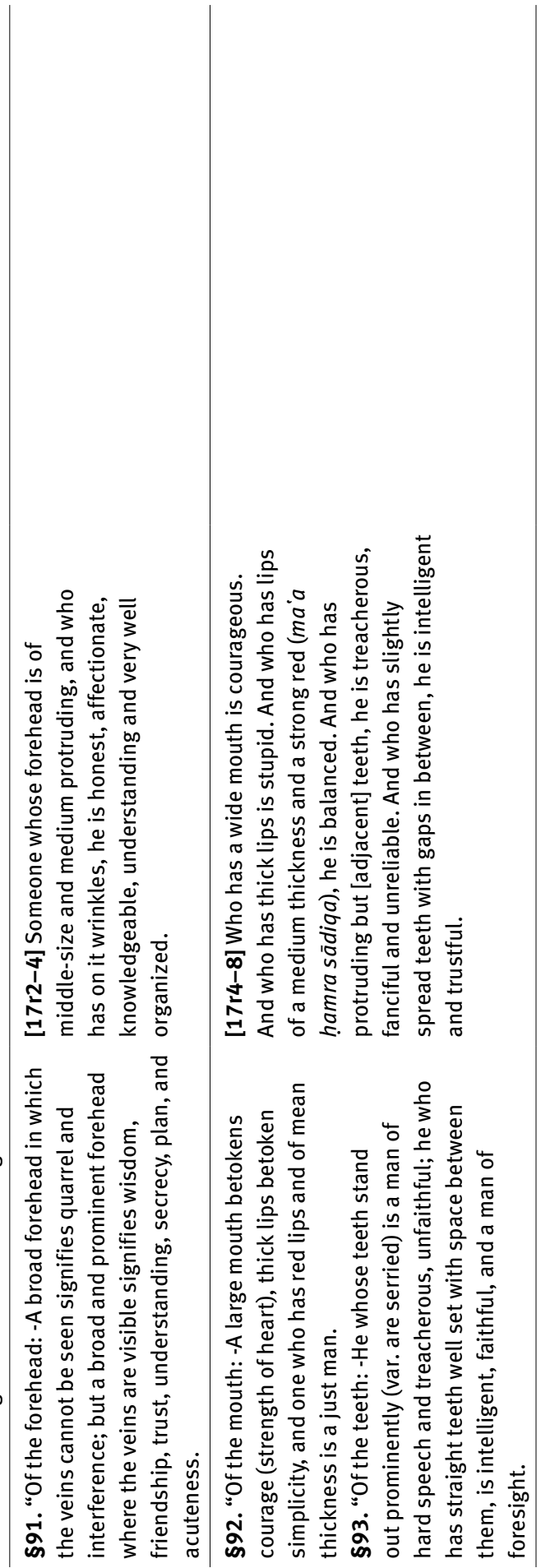




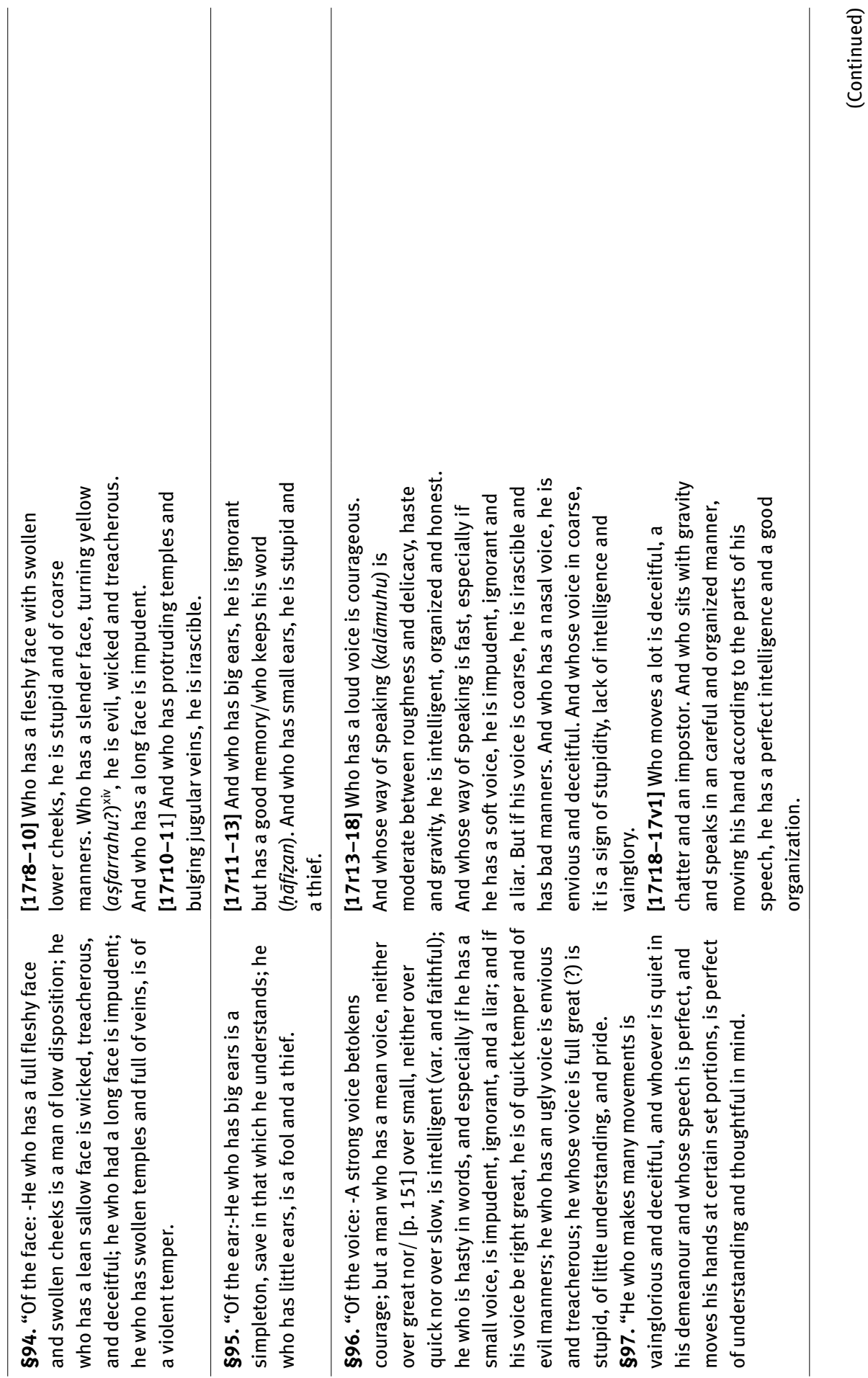




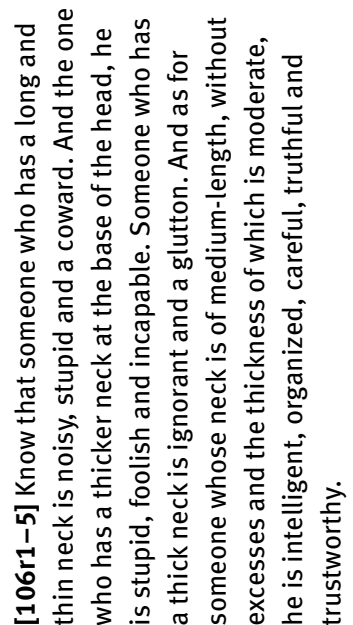

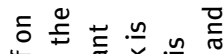

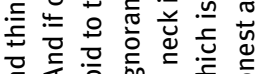

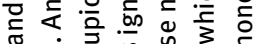

on एं

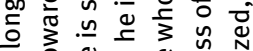

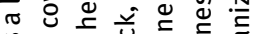

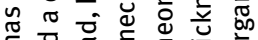

厂 ర

운

了.등

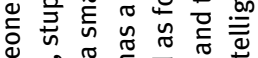

बै

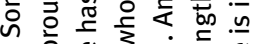

ๆั

눈

I

군

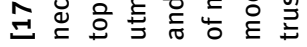

苞

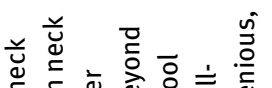

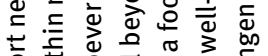

훙

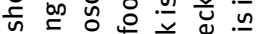

중을

๘

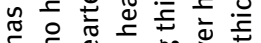

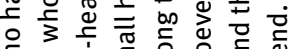

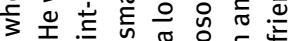

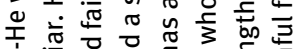

茫 离

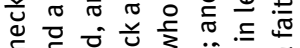

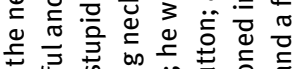

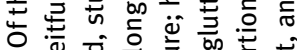

产

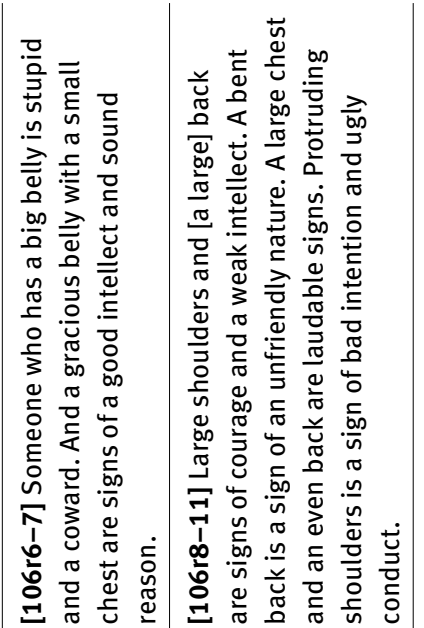

خे

.

蛋守

ज约

․ㅡㅇㅇㅇ

बे

os tos

西 0

त)

定

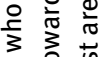

过勻

离

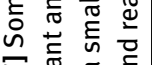

令

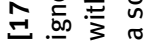

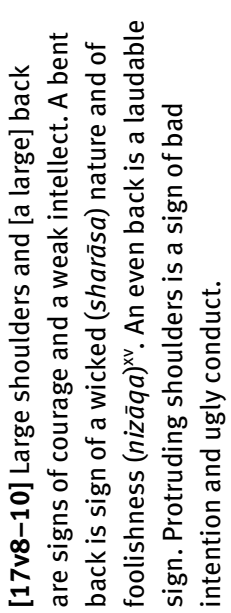

宽

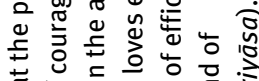

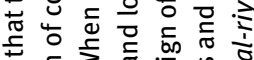

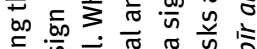

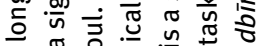

in $\underline{n}$ is

는

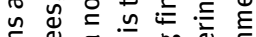

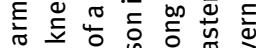

월 물

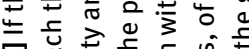

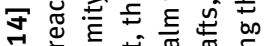

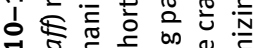

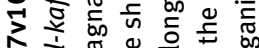

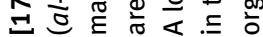

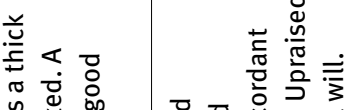

资

号焉

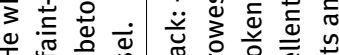

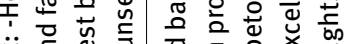

苞它

ᄃ

ర0

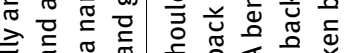

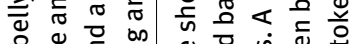

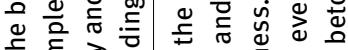

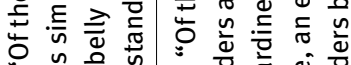

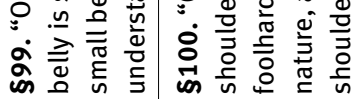

वे बे

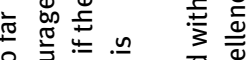

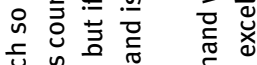

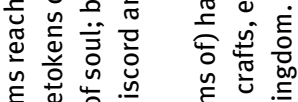

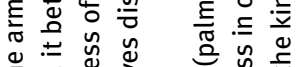

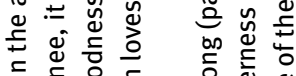

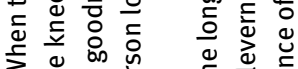

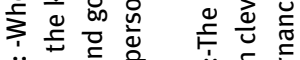

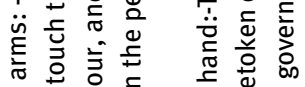

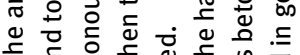
元

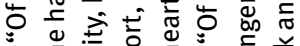

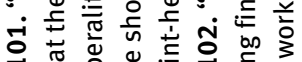




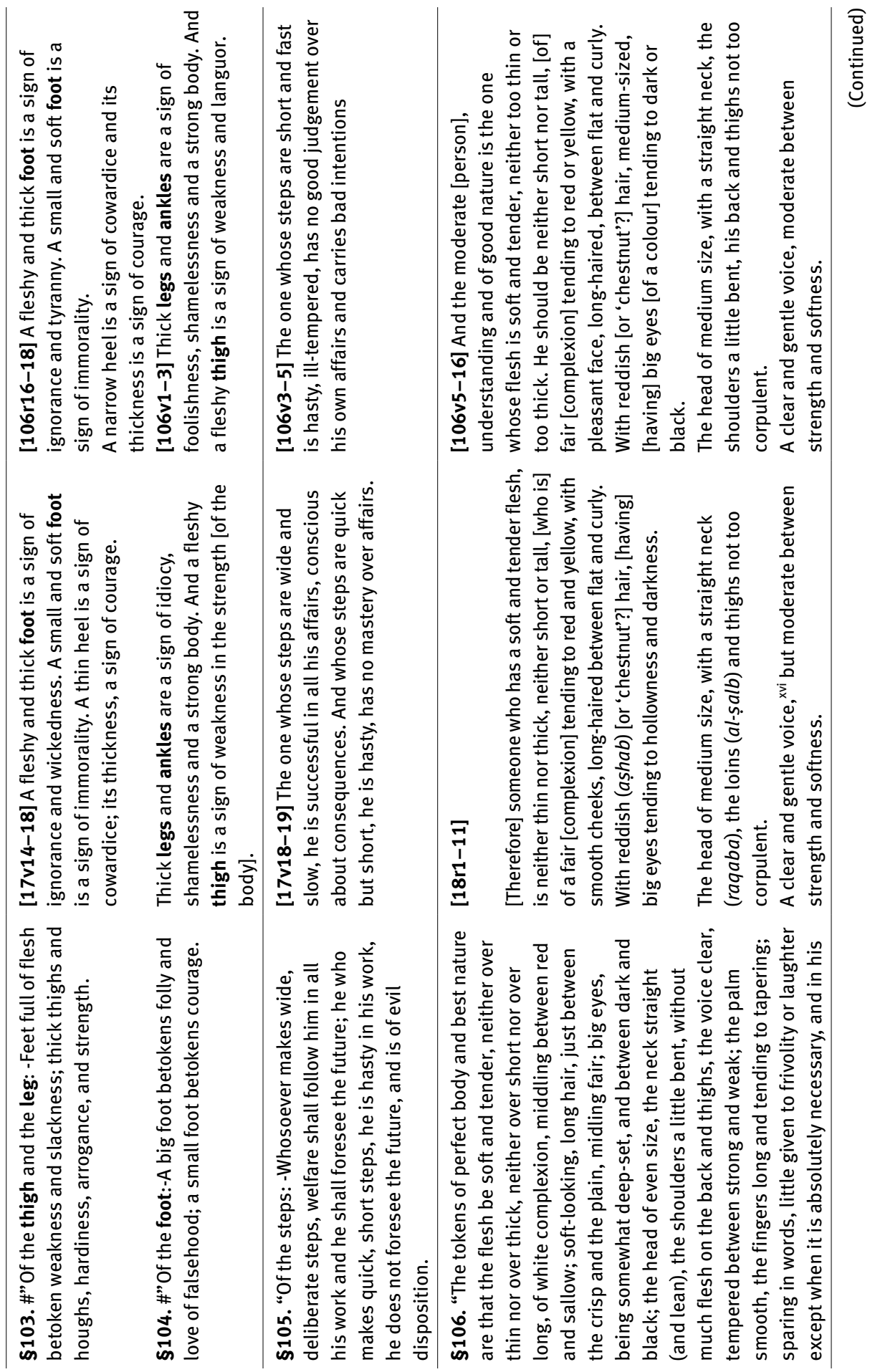




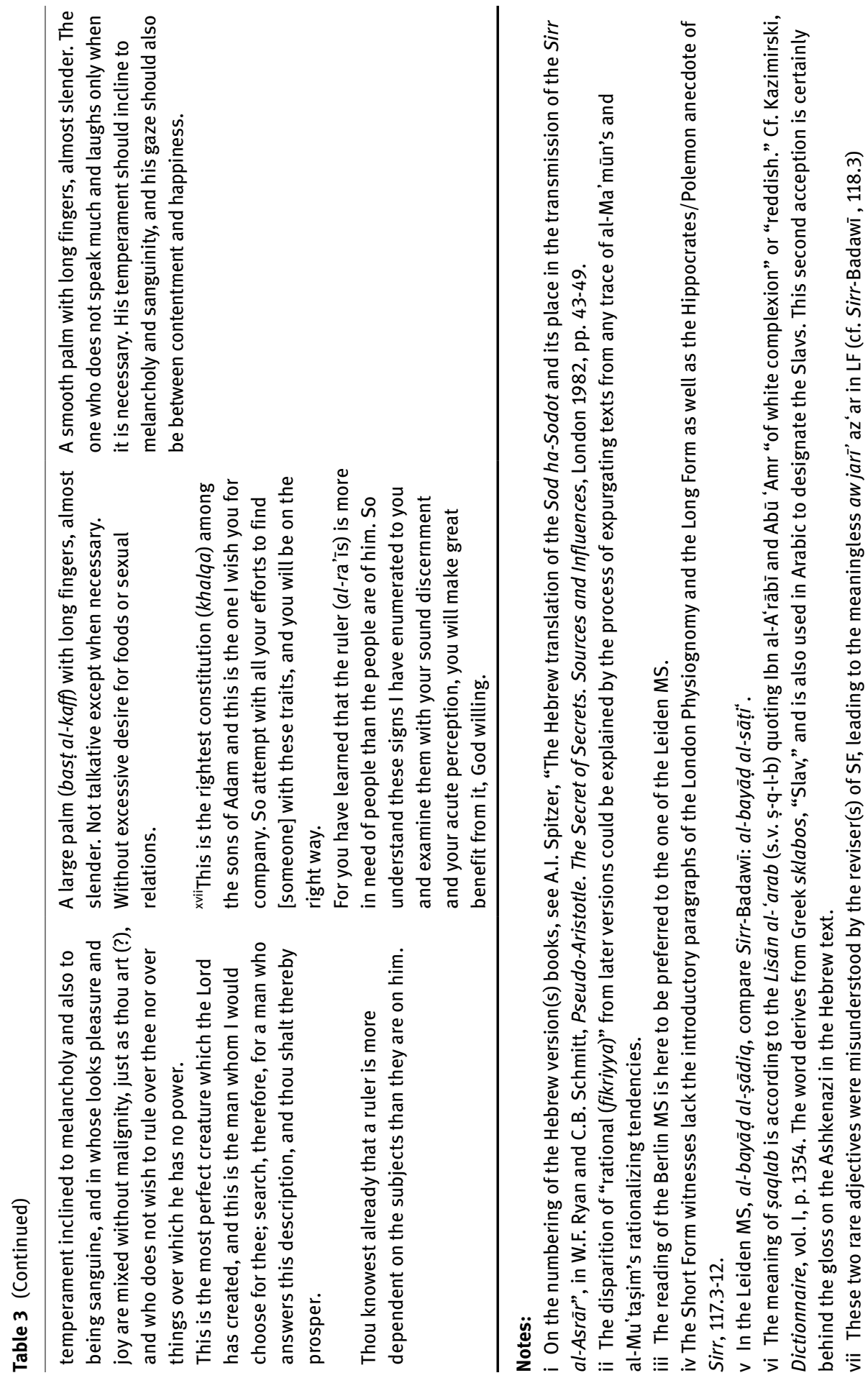




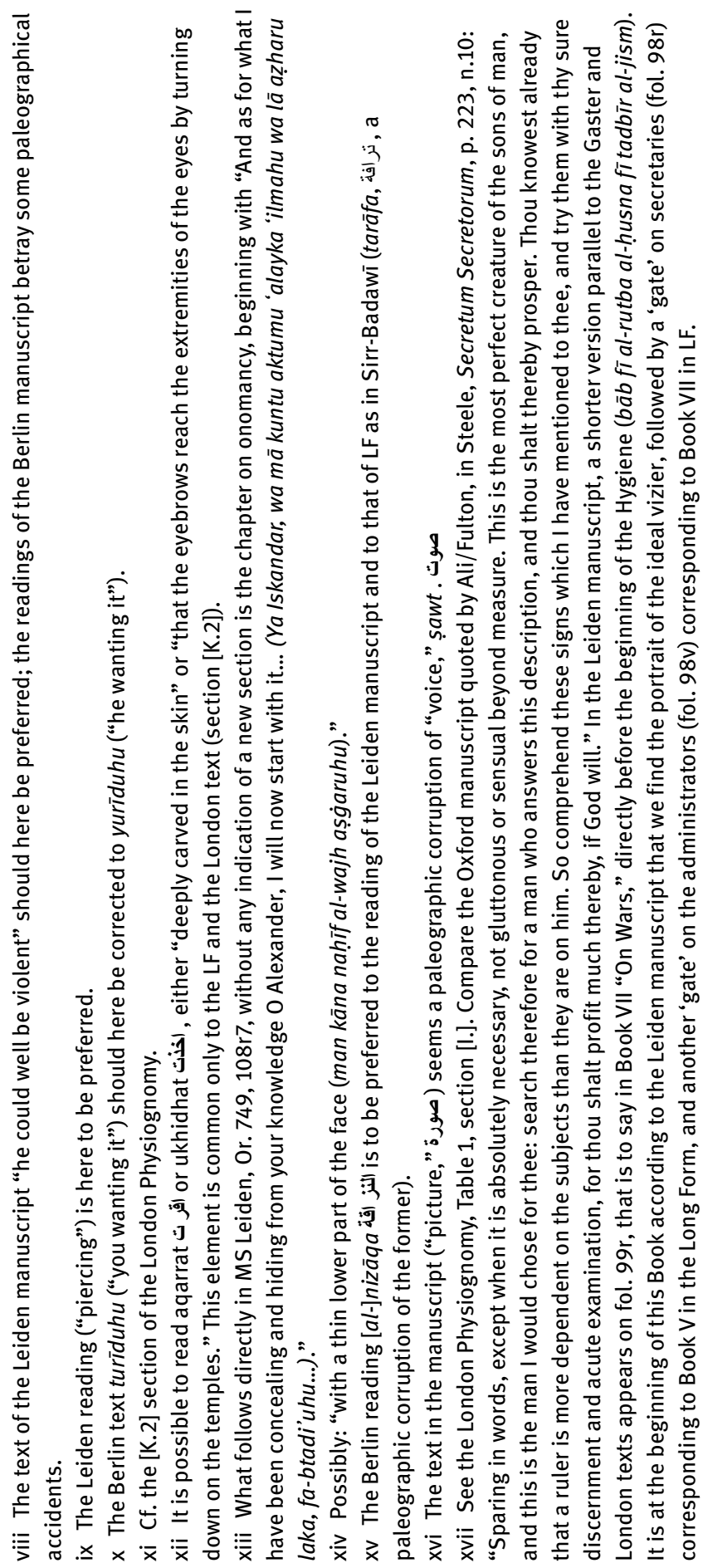


text for which two synonyms are found in the Berlin one. ${ }^{167}$ It is not easy to decide whether these variants should be seen as simple omissions or as stylistic modifications. The missing synonym could have been eliminated because it was felt to be redundant, or on the contrary two close synonyms may be the result of a correction or a marginal gloss by a translator. Retaining two synonyms would then be the result of using hendiadys to nuance the meaning of the first adjective in a specific direction. ${ }^{168}$ In some cases, the addition could also simply be the result of copyists' and reader's glosses, which were meant to explain a term that was seen as obscure or archaic.

\section{Conclusions}

The Short Form in eight books is of interest in that it seems to be the form which was in circulation in al-Andalus as early as the second part of the tenth-century. Ibn Juljul (d. 994 CE), a physician at the Umayyad court in Cordoba, refers to the eight books of the Kitāb al-Siyāsa fì tadbīr al-riyāsa al-ma'rūf bi-Sirr al-asrār ("The Book of Government in the organisation of the state, known as the Secret of Secrets") and gives a number of quotations from the book. ${ }^{169}$ One of these quotations is the famous Circle or Octagon of Justice, a "chain poem" with eight maxims on the organisation of the State. ${ }^{170}$

"The world is a garden, whose fence (siyāj) is the State (dawla). The State is a sovereign (sultān), who perpetuates (yuhyā bihi) the custom (sunna). The custom is a policy (siyāsa), directed by the king (malik). The king is a shepherd ( $r a \bar{i} i n)$ supported by the army (jaysh). The army is [composed of] helpers ( $a$ 'wān) guaranteed by money $(m \bar{a} l)$. Money is provision (rizq) accumulated by the subjects (ra iyya). The subjects are

167 See the variants in the notes to the Appendix, nn. ii; xxiii; xliii; xlvi; liv; lvi-lvii; lviii; ci.

168 On the methods of the translators, see Rosenthal and the various publications of Sebastian Brock dealing with the specificities of Syriac translations, as most of the Abbasid translators were Christians who had been trained in the same methods.

169 Ibn Juljul, Țabaqāt al-ațibbä' wa-l-hukamā', ed. Sayyid, 26-27. Grignaschi's attempts to find elements proving that LF was older than SF suffer from too much imprecision. Among other problems mentioned earlier in this paper, his statement that the Sirr-Badawi should be considered a reliable edition of LF is embarrassing. Manzalaoui 1974, 224-225 made definitive remarks on the often weak variants of $L F$ versus the two $S F$ versions.

170 Cf. Forster 2006, 32. The eight maxims forming a chain poem are believed to be of Persian origin, see Forster 2006, 60-63; Van Bladel 2004, 151-172. Manzalaoui 1974, 214, supported the theory of a Persian origin with a parallel on the sovereign's (sulțān) need of viziers and helpers ( $a$ 'wān) in the $\bar{A} d \bar{b}$ b al-șaghìr of Ibn al-Muqaffa ( $d$. ca $757 \mathrm{CE}$ ). The genre is however very ancient and several examples of it can be found in Lao-Tse's Tao Te Ching. 
servants ('abidd) made subservient through justice ('adl). Justice is harmony ( $m a$ 'lüf) and it is the sustainer (qiwām) of the world."171

As Regula Forster emphasized in her work on the Sirr al-Asrār, the chapters constituting a mirror for princes should be distinguished from the rest of the text, in both versions (LF and SF). ${ }^{172}$ The mirror proper makes constant allusion to the Octagon of Justice to the extent that the poem may well be considered the backbone of the Sirr al-Asrār. ${ }^{173}$ What could today be seen as an early definition of feudalism is said to form "the best part of the entire book and the utmost you can achieve (zabda $a^{\mathrm{t}}$ hādhā al-kitāb wa-ḥāmida ${ }^{\mathrm{t}}$ matlabika)" (Sirr-Badawī, 126). According to a report shared by Ibn Juljul and Ibn Abī Ușaybi'a (who probably copied it from Ibn Juljul), it would have been engraved on the (eight) walls of Aristotle's own tomb, as of an epigram. ${ }^{174}$ Thus, the Sirr al-Asrār culminates with the proper understanding of a harmonious system of justice and the eight maxims can be taken by "Alexander" as a summary of the policies he should be applying for a viable State. The vocabulary and themes of the two shortest "Books" of the Short Form (Books V-VI, cf. Sirr-Badawī's Books V-VIII) are reminiscent of the Octagon of Justice (bustān, ra'iyya, quwwād, māl), while (as per the Short Form) Book I addresses the different types of king, Book II the sovereign and his etiquette, Book III the definition of justice and Book IV the vizierate, the administration and the commanders of the troops. The mirror proper can then be considered as a commentary on the Octagon. Its non-systematic and compendial character reflects an epoch, most probably the ninth-century, where the Arabic genre of $a d a b$ was the literary norm. In the comments to the Octagon, the role of ethics and politics is emphasized while the medical and "scientific" teachings are supposed to complete the landscape of an Aristotelian paideia. This is certainly not entirely clear from the text we read in Sirr-Badawī, where the interrupution in Book II by medical and pseudo-scientific matters renders the structure of Books I-IV illogical. Accidents such as the missing titles of Book III in the Berlin Sprenger manuscript or that of Book IV in the Leiden Short Form manuscripts should be investigated alongside the oddities of the tables of contents. ${ }^{175}$ The inadequacy of a title

171 Cf. Forster 2006, 62; Van Bladel 2009, 216, and a slightly different version in Van Bladel 2004, 160-162. 172 Forster 2006, 56.

173 See Steele 1920, xiii; Manzalaoui 1974, 191. Variants in the formulation of the eight verses from one manuscript to the other have hardly been addressed (but see Forster 2006, 63).

174 Cf. Badawi, Sirr al-Asrār, 126; two manuscripts used by Badawī ascribe the Octagon to the Caliph 'Alī [r. 656-661], cf. loc. cit., 128, n.1; cf. Forster 2006, 32 and 60-63. On early references to the Octagon elsewhere in Arabic and Persian literature (the earliest one being al-Mas'ū ūi ascribing it to Khusraw Anushirwan [sc. Chosroes I, r. 531-579]), cf. Steele 1920, lii; Manzalaoui 1974, 214; Bladel 2004, 160; Forster 2006, 62, n. 337. The motif of the octagonal grave of Aristotle must have been known to Frederick II of Hohenstaufen (r. 1220-1250) for he ordered such a grave to be built for him in Castel del Monte. 175 The interrupting materials in Book II precede a chapter whose main object was the drawing of the Octagon. Likewise, the missing titles of Book III or Book IV may have been the result of codico- 
guided by the illustration such as "On the Drawing (șūra) of Justice" for Book III seems to betray that the table of contents was added at some stage in the composition or revision of the text. ${ }^{176}$ Discrepancies between the different versions of the tables of contents were already pointed out by Grignaschi, who noticed that the table of contents of the Short Form versions as in the Oxford and the Leiden manuscripts were not entirely present in the body of the text. ${ }^{177}$ The missing elements, on the "properties of the animals" and "on poisons" are strikingly close to themes for which Ibn al-Bițīq is elsewhere (in the Fihrist of Ibn al-Nadìm and in Abū Bakr al-Rāzī) credited. ${ }^{178}$ The omission of our manuscripts may have found its way to Roger Bacon's model, for his commentary on the Secretum Secretorumhas a section "On vipers (de viperis)" coming directly after the Physiognomy (in Bacon, corresponding to the place where we find the Tibb al-Rūḥāni in the Arabic Sirr). This was noted by Steele who believed it was a late interpolation taken from Avicenna's Canon, book V. ${ }^{179}$ But Steele himself pointed out parallels between the section “on vipers” and Galen, Ibn Serapion, and even Abū Bakr al-Rāzì’s Tỉbb al-Manșūri so that a borrowing from the Avicennan "Qānūn" is not fully established. Vipers form an important section in both the Pseudo-Galenic Ad Pisonem and in the Commentary on the Theriac ascribed to John the Grammarian and the role of their flesh as an antidote was well-known, just as the extraction of snakes' poison formed an essential part of the literature on poisons and of the works related to the "properties of animals." Tables on the types of vipers used for different theriacs also appear in Ibn 'Arabī’s Qabs al-anwār (cf. MS Leiden, Or. 5, fols $25 \mathrm{v}-26 \mathrm{r}$ ) in between material related to the Sirr al-Asrār. ${ }^{180}$

logical accidents related to the necessity to leave some space or insert the drawing of the Octagon of Justice. See Forster 2006, 24-29, for tables representing the differences from one manuscript to the other and between the two main versions.

176 As suggested by Manzalaoui 1974. In comparison, the Berlin Sprenger manuscripts has a section "Speech on Justice (al-kalām fl-'adl)" (fol. $7 \mathrm{v}$ ) while the drawing (in a circle divided in eight parts) follows on fol. $8 \mathrm{r}$ shortly before the title of Book IV on the same folio (8r ult.). The title "Book III, on the drawing of justice through which sovereignty is achieved and by which the nobles and the common folk are ruled (al-Maqāla al-thālitha fī șūrat al-'adl al-ladhī bihi yukmal al-mulk wa bihi yusās al-'amma wa al-khașșa)" announced in the table of contents (fol. 3r) does not appear, simply replaced with "Speech on Justice."

177 See Grignaschi 1976, 97-101 for a comparison of the table of contents in the Leiden and Oxford Short Form manuscripts, and the Hebrew and Slavic medieval translations.

178 Dunlop 1959, 146-147, cf. Ibn al-Nadìm, Kitāb al-Fihrist, VIII.3, 317 Flügel/ 379 Tajaddod.

179 Steele 1920, xlvi, points to Avicenna as probably borrowing the de viperis section from Abū Bakr al-Rāzīs Ṭibb al-Manșurī.

180 Grignaschi 1976, 13, noticed that the table of contents of SF alluded to sections now missing from both SF and LF, without mentioning Bacon's possible use of the missing section(s). Manzalaoui 1974, 227 remarked that a section on poisons is extant between the talismans and the lapidary in the Hebrew translation and in the Sohaj SF8 manuscript. On the Qabs al-Anwär, see Ghersetti 1999, xiii. The Physiognomy of the Sirr al-Asrār is presented in the form of tables (fols. 
We find in the conclusion of the SF7 Physiognomy text what seems to be yet another possible reference to the Octagon of Justice when "Aristotle" tells "Alexander" that he is more in need of people than they are of him. ${ }^{181}$ This element may indicate that the Physiognomy was part of the original Sirr al-Asrār, unless the remark was taken from the portrait of the vizier (Sirr-Badawī, pp. 138-140) and added to the Physiognomy at some stage in the transmission to enhance the chapter. The Physiognomy may in turn have been part of a "qānūn" and at least some of the scientific material could also stem from this lost text. But without new discoveries of some "Qanūn-related material" in library collections, the history of the composition of the Sirr al-Asrār will remain a mystery. What can be said for now is that, if indeed Aristotle's reminder to Alexander that the ruler is in need of his subordinates and subjects more than they are of him (as an individual who could easily be replaced?) was part of the Physiognomy from the beginning, the fusion of comments on the Octagon of Justice ${ }^{182}$ with scientific excerpts must have occurred at an early stage. Whether the original (by Ibn al-Bițriqq?) was such a balanced Pseudo-Aristotelian treatise on politics, or if the idea came to an early revisor tasked with organizing some existing materials that included Persian, Indian, Arabic fragments and a selection of fragments from Ibn al-Bițrīq's translations, is not known at this stage of research. Systematic comparisons of the three main Arabic versions of the Sirr with all known fragments by Ibn al-Bițrīq would certainly help disclose some of its mysteries. According to Manzalaoui, the main difference between the Long and the Short Forms consists in the addition to the former of long excerpts taken from the Epistles of the Brethren of Purity. ${ }^{183}$ These additions, next to repeated allusions to astrology - a topic nearly absent from the Short Forms - tend

21b-22a) next to other materials deriving from the Sirr (such as the Onomancy, fol. 12b and possibly, but this would be a unique testimony and thus deserves further investigation, a chapter on the decorum of kingly receptions at Indian courts which should be compared with the elements on Indian courtly etiquette and administration in the Sirr for which Manzalaoui discovered direct borrowings from famous Indian treatises on administration such as the Arthashastra, cf. Manzalaoui 1974, 200-201, 211-213).

181 Steele 1920, 223, n. 10 (from the Oxford SF7, cf. identical statement in the SF7 Sprenger 943, 18r; missing in Leiden Or. 749, which is an SF8); Manzalaoui 1974, 223.

182 On the mirror proper, see Forster 2006, 56-75.

183 Manzalaoui 1974, 175-184. Manzalaoui acknowledged his debt to Andries A. Verdenius (18761950), an early twentieth-century Dutch scholar who discovered traces of the Sirr al-Asrār in a 13th-century Dutch poem by Jacob van Maerlant and made the parallel between its contents and the Epistles of the Brethren of Purity (see Verdenius 1917, 27-39). Grignaschi, who had also noticed parallels between the Sirr and the Brethren in his earlier publications tried to dismiss Manzalaoui's findings but no critical edition of the Epistles of the Brethren of Purity was available at the time. The portrait of the ideal vizier is the sole parallel between the Sirr al-Asrār and the Epistles of the Brethren of Purity to be found in both SF and LF. Apart from this section, all the parallels are limited to LF. Cf. Manzalaoui 1974, 176. The additions to the Long Form for which parallels with the Epistles of the Brethren of Purity (Rasā’il Ikhwān al-Ṣafā') were discovered by Manzalaoui belong to a larger reediting in which most of the astrological material was also added. A specialist of the 
to indicate that the Long Form conforms to a certain mindset differing from the one found in the Short Forms. Keeping in mind the central role of the Octagon of Justice, differences between LF and SF might reflect a different organisation of government.

The eight verses of the Octagon of Justice, and the eight books of the Short Form, would point to a composition in eight-books as the original version of the text. In fact, insistance on number eight reappears throughout the Sirr al-Asrār. A section (pp. 108-114 Sirr-Badawī) on an electuary in eight parts composed by eight physicians is inserted between the recommendations on baths and advice on the propitious time for medical bleedings and the drinking of medicines. ${ }^{184}$ "Aristotle" after referring to a book of his composition "On Water" and another one "On Simple remedies, potions, balms and onguents according to the traditions of the Rūm [i.e. the Romans or the Byzantines], Indians, Persians and Ancient Greeks (yūnāniyyin)" explains that people differ on the inventor of the panacea, ascribing it to either Adam or Asclepius (Sirr-Badawī, p. 107). The pompous sentence "the honorable eight sages who studied the hidden sciences - the secret of creation, what is above physics, from void, full and the limit ${ }^{185}$ - agreed on the compo-

Epistles concluded that there was a single authorship for the Sirr al-Asrär and the Epistles, cf. alTuraykī 1973.

184 The reference to eight physicians is reminiscent of a famous "ogdoad" of physicians found in a romanticized biography of Galen preserved in its fullest version in the Choicest Maxims and Best Sayings, by the Fatimid author al-Mubashshir ibn Fātik (composed in 1048). The spurious ogdoad, starting with Asclepius I and ending with Galen, is somehow related to a late Alexandrian text ascribed to one "John the Grammarian" (whose medical commentaries to Galen were wide-spread). The ogdoad was also known to Ishaq ibn Ḥunayn (d. ca 910) who made use of it in his Ta'rikk al-ațibbä', from which it passed in various subsequent works. The parallel with the ogdoad of physicians in the Ta'rikh al-ațibb $\vec{a}$ ' was noticed by Steele (1920, xlvi) via a quotation from Ibn al-Nadīm's Fihrist. The spurious Galenic biography was studied by Swain 2006, 395-433. The ogdoad borrows the idea of an Asclepiad genealogy from the Pseudo-Hippocrates' Letter II (also found in the London manuscript, see supra sections I.1 and I.2 of this paper). Another series, this time of nine physicians, appears (with Andromachus the Elder and the Young instead of Asclepius I and II) as a literary motif used in the preface and the illustrations of the Book of the Theriac (Kitāb al-Diryāq), a late avatar of the Pseudo-Galenic Ad Pisonem said to be transmitted according to the summary (purportedly?) made by the Alexandrian John Philoponus or another Alexandrian physician who shared the widespread nick-name of John the Grammarian. Interestingly, Bacon has nine remedies (see Steele 1920, 103 and 276) where LF has only eight. According to Hunayn ibn Ishāq, who owned a copy, the Arabic version of the Ad Pisonem was probably translated by Ibn al-Bițīq from Syriac, on a text provided to him by Job of Edessa, who had translated it from Greek (before 832 CE). On the Ad Pisonem, see Leigh 2013; Richter-Bernburg 1969. Hunayn's epistle on the translations of Galen was edited twice, by Bergsträsser 1925, and Mohaghgheg 2001 (the Ad Pisonem is $n^{\circ} 83$ in both editions). The names of the physicians in the Sirr al-Asrār's ogdoad have been corrupted, modified and corrected through the times by copyists borrowing from these lists (Ishāa b. Hunayn, the Arabic Ad Pisonem and related works, such as Yahyā al-Naḥwīs commentary of Galen's Electuaries, Fì al-ma jūnāt, sc. the Ad Pisonem or possibly de De antidotis [MS St Petersburg, Saltykova-Stchedrina, cf. Dorn n 123, copied 993 AH]). Cf. Richter-Bernburg 1969, 90 for the names of the authors of theriacs according to the Arabic Ad Pisonem.

185 Al-nihāya would need to be emended into al-lānihāya ("the infinite"). 
sition of this sublime medicine and they divided it into eight parts (al-hukamä' al-jilla al-thamāniyya al-ladhīna ațla 'ū 'alā al-ulūm al-khafiyya min sirr al-khalīqa wa mā ba'd al-țabí' a min al-khalā' wa al-milà' wa al-nihāya, ittafaqū 'alā tarkīb hadhā al-dawā' al-jalīl wa qasamūhu thamāniyyat aqsām)" makes transparent allusion to the Sirr al-khaliqa and to the Metaphysics, further pointing to Ibn al-Bițīq and early ninth-century Abbasid circles as involved in the Pseudo-Aristotelian forgery that is the Sirr al-Asrār. The eights remedies are supposed to form, once taken together, a panacea. As with the theriac of the Ad Pisonem, the base ingredient of each recipe should be honey. The echoes of works related to the preparation of the theriacs raise the possibility that the section on the eight remedies was actually part of what Grignaschi considered the missing sections on "the antidotes of poisons" and "the properties of the animals," announced in the table of contents of some Short Form manuscripts but missing from the preserved text. ${ }^{186}$ Finally, yet another instance of a symbolical use of the number eight was discovered by Manzalaoui in what he calls an "analogue" (not an exact literary parallel) to the section on Hygiene in the Sirr in the Pseudo-Ghazālì's Counsel for Kings (Nāṣiḥat al-Mulūk), where the Sasanid vizier Buzurgmihr gives a list of eight pieces of advice related to the eyes, the body, the heart, etc. ${ }^{187}$

The comparison of the Physiognomy chapter preserved in the London manuscript has allowed us to establish that the manuscript should not be seen as a simple "forgery." The parallels between the London Physiognomy and both the Long and the Short Forms in some specific details confirms its value as a witness of the text, as was already understood by Manzalaoui and by Grignaschi. Grignaschi's hypothesis, namely that the London Physiognomy belonged to a Kitāb al-Qānūn used in the process of compiling the Sirr al-Asrār, will be hard to establish without the discovery of new fragments of the Qānūn. Among the questions raised by these parallels are the availability of the Qanūn to Abū Bakr al-Rāzì or the anteriority of the latter, and the possibility that Rāzì's own files and archives were used and compiled during the process of composing the Sirr al-Asrārr. ${ }^{188}$ Alternately, if the Kitāb al-Qānūn could be traced to Ibn al-Bițīq, we may wonder if it was known to Rāzī - who used Ibn al-Bițrīq's in his medical writings - as can be seen from the quotations in the Kitāb al-Hāwi (the Liber Continens of the Western medieval physicians). ${ }^{189}$

186 Rāzī vaguely mentions "Ibn al-Bițrīq in his book on poisons.” Richter-Bernburg 1969, 111-215, gives the parallels between the Arabic Ad Pisonem and Rāzī's Hâ̄wī in his commentary to the text.

187 Manzalaoui 1974, 221.

188 The parallels with Abū Bakr al-Rāzì’s physiogomical section in the Ad Mansorem (al-Tibb al-Manșūrī) were noted as early as Förster, cf. Manzalaoui 1974, 227, adding the hypothesis that Rāzī may have used the Sirr.

189 No critical edition of Rāzī's opus magnus, the Kitāb al-Hāầ, is available. A searchable version of the text (based on the Hyderabad edition [1955-1970] or on the pirate version of it published in Beirut 2000) is hosted on www.alwaraq.net. Unfortunately, none of the paper editions I have seen offered an index. An automatized search on the "alwaraq" website for Ibn al-Bițīq's quotations in the $H \bar{a} w \bar{\imath}$ turns more than twenty results. 
Unfortunately, Rāzì’s works were almost entirely lost, because of his reputation as an atheist, his strong advocacy of philosophy, and his attacks on the theory of prophecy. ${ }^{190}$ Nevertheless, Steele and Badawī showed that traces of Rāzì were everywhere in the medical contents of the Sirr al-Asrār. Steele in particular noticed several parallels between the medical sub-sections of the Sirr and the works of Rāzī, and a full comparison will be needed. ${ }^{191}$ Among these parallels, the chapter of the Sirr on anatomy, which Steele traced to a treatise by the Pseudo-Diocles of Carystus, was known to the seventh-century Paul of Aegina, a medical authority regularly quoted by Rāzī. ${ }^{192}$ A literal parallel can be further noticed between Rāzī's Tịbb al-Rūhāañ̄ and the Sirr al-Asrār in the quote ascribed to Hippocrates according to which "one should eat to live and not live to eat." ${ }^{193}$ As already mentioned, Grignaschi remarked that a paragraph on "spiritual medicine (țibb rūḥānī)" concludes the section on Hygiene in the Long Form (albeit missing in Badawī, see Ali/Fulton in Steele 1920, 216-217 where it follows the panacea and paragraphs on cupping and the appropriate time for taking remedies - according to astrological configurations). ${ }^{194}$ The paragraph on spiritual medicine addresses mental diseases and the efficiency of music in curing them, echoing Pythagoras on the role of music in conveying the harmonious melodies produced by the celestial spheres. Another hidden reference to Rāzī appears at the end of the section on baths, when "Alexander" is being told that should he follow the advice, he will not be in need of a physician. But if borrowings from Rāzì can be detected throughout the Sirr al-Asrār, its philosophical and astrological contents seem rather alien to anything ascribed to him. The constant reference to astrology in the inserted medical sections were possibly added to some genuine Rāzī material, and the numerous references to titles of his works may eventually turn out to be attempts to ascribe to him theories entirely foreign to his way of thinking. ${ }^{195}$

190 A list of his books was drawn up by al-Bīrūnī, who lived a century after Rāzī. The traditional religious formulas and invocations in the Tỉbb al-Rūhānī strike me as possible late additions. Alternately, the fact that the book was dedicated to a Samanid prince may have obliged the author to a certain degree of formality.

191 See Steele 1920, xlvi (de viperis); xl (on the "poison maiden"); lxiii (physiognomy); xlv (de divisione corporis; de conservantibus sanitatem; de cibis); 273-274; 277.

192 Steele 1920, xliv; 272-273. See the recent study of the text by Pormann 2004, 50-56. Pormann's analysis of the quotations of Paul in Rāzĩ enabled him to state that the latter often reformulates his model.

193 The maxim is common in medical literature, see Manzalaoui 1974, 232-233.

194 Grignaschi 1976, 43. Manzalaoui 1974, 169, lists the manuscripts from where the "spiritual medicine" section is missing. Steele 1920, 217.

195 In the same vein, the Ismaili propagandist Ḥamīd al-Dīn al-Kirmānī (d. after 1020 CE) used Rāzīs Tỉbb al-Rūhānī thoroughly to compose a refutation of it and of the thinking of Rāzì's in general. See Al-Kirmānī 1977. The title is plagiarizing the Arabic version of Pythagoras' Golden Verses (al-aqwāl al-dhahabiyya) in Arabic. 
To emphasize the likeliness of the role of Ibn al-Bitrīq in the composition of the Sirr al-Asrār, an element of the preface can be related to works he translated. The legendary story of the discovery of the Sirr al-Asrār by Ibn al-Bițīq in a Greek temple is paralleled by yet another such legend, this time in the Pseudo-Hippocratic Signs of Death ( $f \bar{i}$ 'alāmāt al-mawt), for which a commentary or paraphrase seems to have been composed by Ibn al-Bițīq. ${ }^{196}$ According to Ibn Juljul, Ibn al-Bițrīq's father was a practicing physician while his son focused on philosophy more than on medicine. ${ }^{197}$ If true, the father's translations - made at a time when translators were simply considered as low-level employees of the chancellery whose names were not worthy to be mentioned - could well have passed under the son's name, who by all means would certainly have inherited his father's archives, so some of the medical and scientific sections of the Sirr may belong to either one of them. Ibn al-Bitrīq's name is attached to the lost translation of Plato's Timaeus but also to that of a number of Aristotelian works: On Heaven, the Meteorology, and possibly some of Aristotle's works on animals (which include the History of Animals, the Generation of Animals and the Parts of Animals). ${ }^{198}$ As Ibn al-Bitrīq's translation of an Aristotelian work on zoology has not been identified, ${ }^{199}$ we cannot know for sure if the bibliographers were not confusing the famous Aristotelian books with the sections on the animals in the Pseudo-Aristotle's Physiognomy, or even with Ibn al-Bitrīq's contributions on the knowledge of poisons and on the "types of crawling animals (ajnās al-hasharāt)" (Fihrist, p. 317 Flügel/p. 379 Tajaddod). Possibly related is also a paragraph on the vices and virtues that were seen as characteristic of various animals which follows directly the portrait of the ideal vizier in Book IV and has been shown to bear echoes of Galen's On Character Traits (Greek Peri Ethôn, Latin De moribus, Arabic Fū quwā al-nafs and Kitāb al-akhlāq). ${ }^{200}$

196 Mourad 1939, 41-43. The Pseudo-Hippocratic “On the Signs of Death ( $f \bar{i}$ 'ālamāt al-mawt)" is also known under the title "On pustules ( $f$ ì al-buthūr)."

197 Ibn Juljul, Țabaqāt al-ațibbā', 67 (ed. F. Sayyid). Ibn Abī Ușaybi‘a, 'Uyūn al-anbā', vol. I, p. 205 (ed. Müller) judged Ibn al-Bițīq's translations as weak, refering to him as a lạținī who had no knowledge of ancient Greek (i.e. of Ionian, Dorian and/or Attic versus Byzantine Greek ?). Endress 1966, 94, may be right when he interprets the sentence as meaning that Ibn al-Bițīq knew only the modern script and orthography but not the uncial one, however, the role of his father at al-Manșūr's court (r. 754-775) and his own position in al-Ma'mūn's circle points to the fact he certainly grew up at the Abbasid court and was for this reason not trained in the classical curriculum in the same way his father had been. Oddly enough, the Leiden MS (Or. 749, fol. 78r) reads rūmānī.

198 On the works ascribed to Ibn al-Bițīq, see Dunlop 1959; Endress 1966, 89-98. Echoes of Plato's Timaeus and Republic or that of Aristotle's Meteorology are noticed by Steele and Manzalaoui throughout the Sirr al-Asrār.

199 Stylistic comparisons led Endress 1966, 113-115, to reject the attribution of the translations from Aristotelian books on zoology we possess to Ibn al-Bițīq. Brugman and Drossart Lulofs 1971, in their edition of the Generation of the Animals, and Kruk 1978, in her edition of the Parts of the Animals, have agreed with Endress' findings.

200 Manzalaoui 1974, 198-199, further pointing to the parallels with Plato's Republic, which is certainly (with the Timaeus) one of the sources of inspiration of Galen in this treatise. The title Kitāb 
The portrait of the ideal vizier, whose relation with the philosopher-king of Plato's Republic VI has long been noted, is in turn likely to stem from Hunayn's translation of an epitome of the Republic which may well have been Galenic. ${ }^{201}$

Ibn al-Bitrīq and Job of Edessa's association situates the composition of at least some parts of the Sirr al-Asrār to the first quarter of the ninth-century and earlier. ${ }^{202}$ The association of the two scholars, whose backgrounds made them more at ease in Greek and Syriac than in Arabic, in an environment where Persian was used between members of the court on the same level as Arabic, could argue, in my opinion, for the awkard syntax often encountered in the earliest versions of the Sirr, mainly represented by Short Form witnesses. Al-Ma'mūn's court would also be a place where Persian and Indian treatises on administration and government could be discussed. Despite the little we know about Ibn al-Bițīq, the contents and the context of the Sirr al-Asrār led modern authorities such as Badawī and Van Ess to accept the attribution to Ibn al-Bitrīq. This does not imply of course that everything we read about Ibn al-Bitrīq in the introduction of the Sirr should be taken for granted. ${ }^{203}$ But the majority of the philosophical and medical themes found in the Sirr can be paralleled with one or the other of the translations ascribed to him or to his father. Some striking formulas could even possibly reflect his Christian background: “...think about what Cain did to Abel his brother...” (Steele, Secretum, 247; cf. Sirr-Badawī, 149) or “...and I left this composite, earthly temple (haykal) to corruption and annihilation...” (Steele, Secretum, 261; cf. Sirr-Badawī, 165). ${ }^{204}$

To conclude on the value of the London manuscript for future studies, the internal evidence lines up perfectly with the dating of the manuscript that is provided in the colophon, which may well have been copied by a modern copyist who tried to remain faithful to his model. Whether this copyist was an 18th-century figure ordered to make a book "look old," or someone in early 20th-century Tehran working for a bookseller and antiquarian who specialized in fakes and facsimile reproductions should be further investigated by specialists in codicology. As far as its scientific examination is concerned, discarding an ancient artefact as a "fake" without fully analyzing its contents does not hold up outside of the auction room. Scientific methods describe and

al-Akhlāq li-Jālīnūs (Galen's Ethics) is the title found in the Cairo manuscript (MS Dār al-kutub, Akhlāq 290, 191-235) edited by Kraus 1937.

201 Manzalaoui 1974, 198-199.

202 Job of Edessa's dates are not debated, but those of his younger contemporary Ibn al-Bițīq (d. ca 840) are more obscure because of the confusion made by several authors between him and his father. The date corresponds with the rising popularity of physiognomical treatises. Polemon's name is mentioned by al-Jāḥiz (d. 255/869) and al-Ya'qūbī (d. 284/897), cf. Hoyland 2006, 312; Thomann 2003.

203 Forster 2006, 12, n. 10; cf. Badawī, Sirr al-Asrār, introd., 33-39 and Ess (van) 1991, 411. Endress 1966, 92, notes however that Ibn al-Bitrīq is mentioned as a member of the expeditions sent in quest of books to the Byzantine Empire by al-Ma'mūn. The legendary overtones of the preface of the Sirr al-Asrār should be seen as reflecting the taste of the day.

204 Manzalaoui 1974, 221, notes that the expression is in the (Arabic) New Testament. 
examine objects from different angles which all have their own specific value. To give but one example, Galen of Pergamon (129-216) had to publish his own bibliography (under the title “On My Own Books", Lat. De libris propriis) to counter the number of forgeries under his name on the markets of Rome and Alexandria, but there is no doubt that any such text, if extant, would inform us about the philosophical and medical debates of his time.

\section{Appendix : Arabic text of the Physiognomy chapter in MS Leiden, Or. 749 (SF8) and the variants of MS Berlin, Sprenger 943 (SF7).}

MS Leiden, Or. 749, fols. 106v17-108r7

بابن في الفر اسة

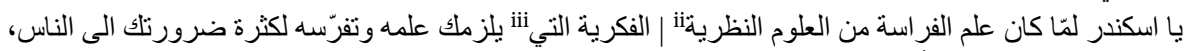

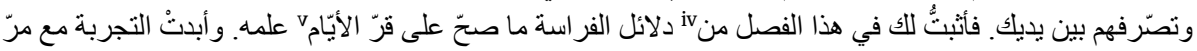

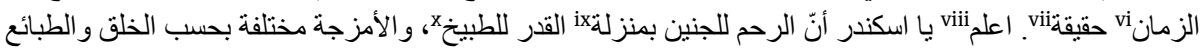

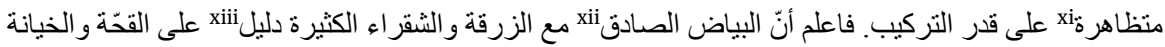

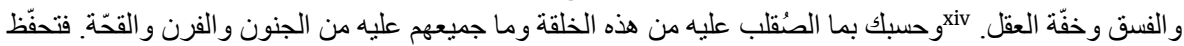

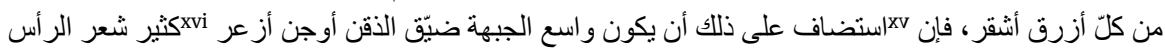

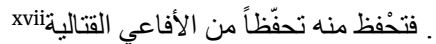

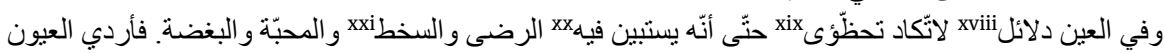

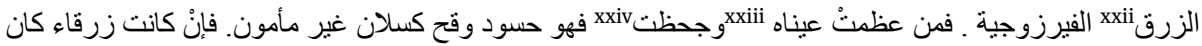

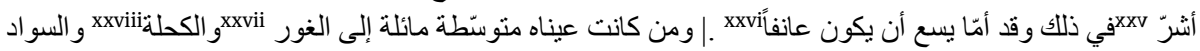

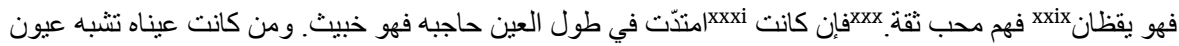

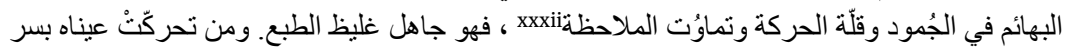

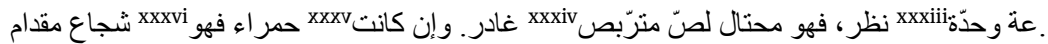

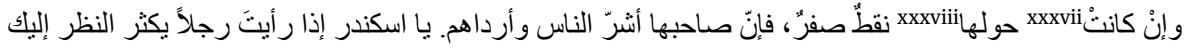

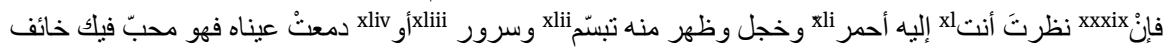

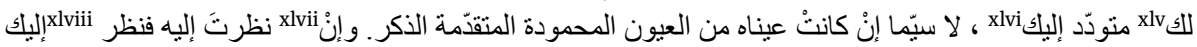

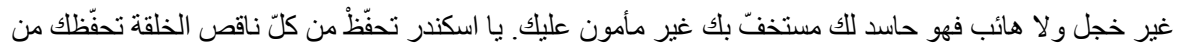
عدوّك.

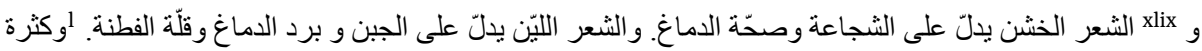

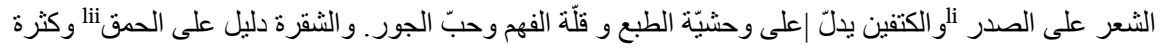

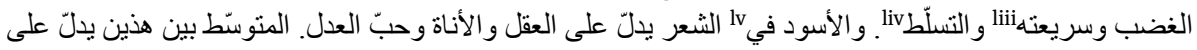

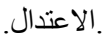

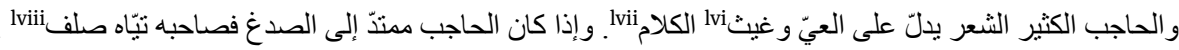

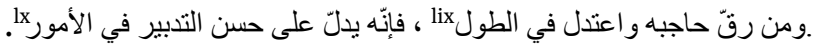
lxi[.... 108r7-8] 
MS Leiden, Or. 749, fols. 106r1-106v16

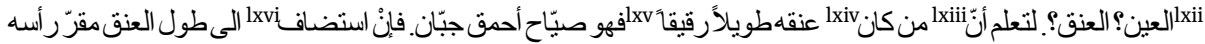

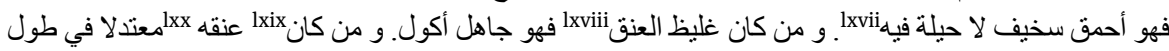

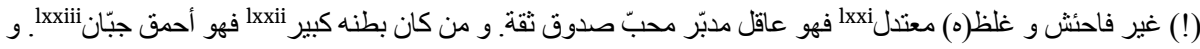

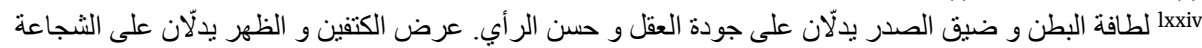

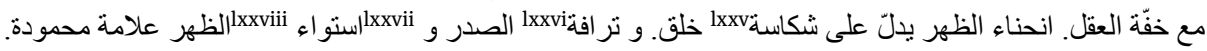

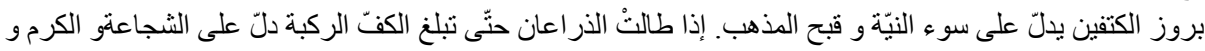

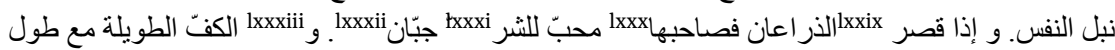

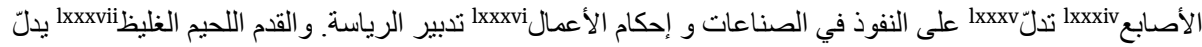

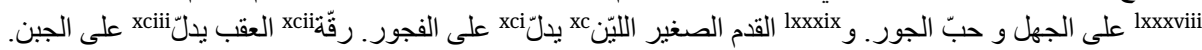

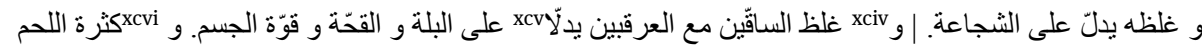

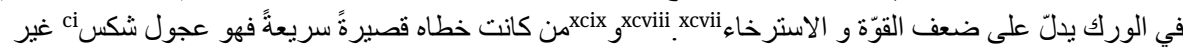

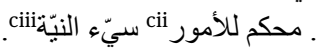

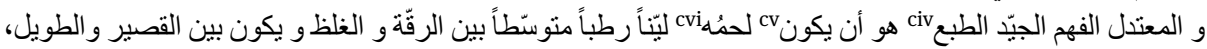

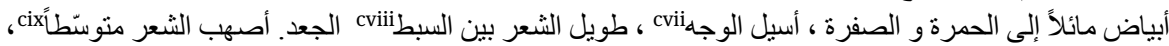

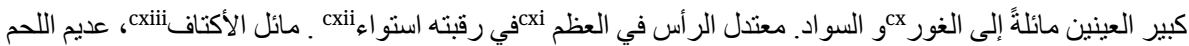

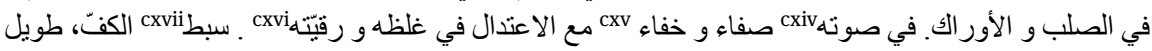

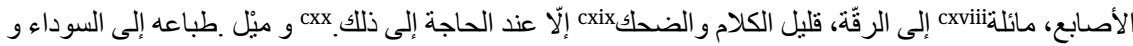

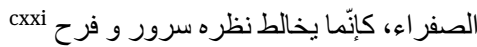

\section{Notes:}

i القول B [= MS Berlin, Sprenger 943, fols. 16r-18r].

ii النظرية اللطيفة B.

iii الذية B.

iv من omitted in B.

v على الزمان B.

vi الأيام B.

vii حقيقته ان شاء الله تعالى B. B.

viii قد علمت B.

ix مثل B.

X للطبخ B.

xi منضادة B.

xii الساطع B.

xiii دليلة B.

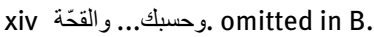

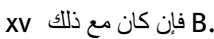

xvi أوجن أزعر : أو كان Bل

xvii القتالية omitted in B.

xviii يا اسكندر دلائل العيون B.

xix تحظيك B. تصفيك B.

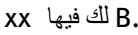

xxi الغضب B. 
xxii فاردي العيون الزرق واردي الزرق B.

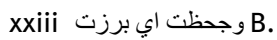

xxiv MS Leiden : جحضت.

Xxv اشد B.

xxvi وقل ما بسلم ان يكنون عيونا BxV B.

xxvii الغورة B.

xxviii و الكحل B.

xxix يقضان B.

$x x x$ The whole sentence is missing from the Berlin manuscript.

xxxi MS Leiden : فإنْ كانت dittography.

xxxii وتماوُت الملاحظة omitted in B.

xxxiii وخفة

xxxiv مترَبص omitted in B.

xxxv فإن كانت العينان B.

xxxvi فصاحبها B.

xxxvii كان B.

xxxviii حو اليها B.

xxxix,$B$.

xl أنت omitted in B.

xli فأحمر B.

xlii وظهر منه تبسّم ولا تريده فيمر.

xliii وسرور omitted in B.

xliv و B.

xlv خائف منان B.

xlvi منودّد إليك منك مانك omitted in B.

xlvii فرد النّ B.

xlviii ونظر B.

xlix ورونظّ B.

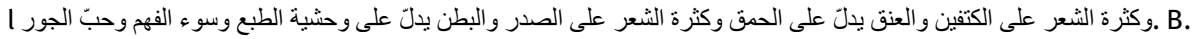

li MS Leiden : الهرر

lii الحمق و omitted in B.

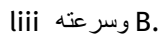

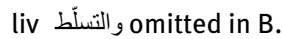

Iv من B.

Ivi العيّ و غيث omitted in B.

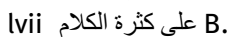

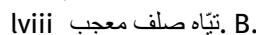

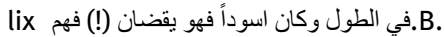

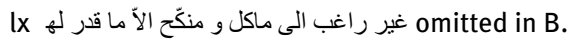

Ixi What comes here in the Leiden manuscript is the beginning of the Onomancy. Instead of the Onomancy, the Physiognomy is followed in the Berlin manuscript with the heading of Book VII "On Medicine (al-Maqāla al-sābi a fi al-țibb)." What should have followed the sentence on the eyebrows is, according to the Berlin manuscript, the sections on the nose, forehead, lips, teeth, face, temples, ears, the voice and way of speaking, the movements and way of sitting (MS Berlin, Sprenger 943, foll. 16v16-17v1, i.e. about the length of one side of a folio). At the end of the Physiognomy section on $108 \mathrm{r} 7$, the word karrir ("repeat, reiterate") is visible as well as on the last line of the folio, possibly a copyist's note after he realized his mistake.

Ixii An accident in the binding (or already in that of the archetype used by the copyist) of the Leiden manuscript resulted in some accidents in the order of the parts and of the disappearance of 
the sections between the eyebrows and the neck. None of the folios in the Leiden manuscript gives the catchword العين "al- "ayn" which would be expected to come before the beginning of folio 106. It is not entirely impossible that a paleographical accident resulted in that العنق was misunderstod and copied العين and in fact the reading al-'ayn seems the result of added dots by another hand on what was initially العنق "al-"unq." The length of the lacuna between the two remaining parts of the text in the Leiden manuscript (see Table 3) would correspond to one side of a folio.

lxiii لا تعلم ان omitted in B.

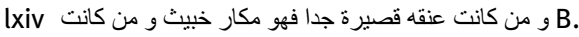

lxv طويلة رقيقة B. The use of 'neck' in the feminine is also attested in the London Physiognomy, cf. supra Table 1, [K.10].

Ixvi MS Leiden: استظاف. The expression istadāfa ilā appears already at the beginning of the text. Cf. Kazimirski, Dictionnaire, vol. II, p. 147, ẓāf and ẓüf mean 'the neck's skin,' a possible reason for the confusion of the copyist?

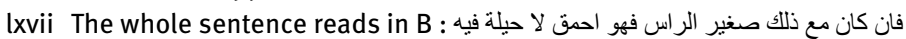

lxviii و من كانت عنقه غليظة B.

lxix كانت B.

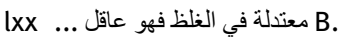

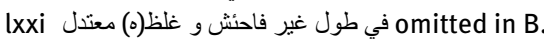

Ixxii كبير B.

lxxiii جاهل جبان B.

Ixxiv gomitted in $B$.

lxxv شراسة B.

Ixxvi و النزاقة B. B.

lxxvii الصدر و omitted in B.

lxxviii استواي B.

Ixxix قصرت B.

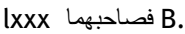

lxxxi جبار محبّ للثرّ B.

lxxxii جبان omitted in B.

Ixxxiii , omitted in B.

lxxxiv الأصابع الطول B.

lxxxv بدل B.

lxxxvi و و تنديير B. The و is missing in the Leiden MS.

Ixxxvii اللحيمة الغليظة تصنة B.

Ixxxviii تدلّ B.

Ixxxix g, omitted in B.

xc الصغيرة اللينّة B.

xci تدل

xcii رو روقة B.

xciii تدلّ

xciv, omitted in $B$.

xcV يدل B.

xcvi, omitted in B.

xcvii و و الاسترخاء omitted in B.

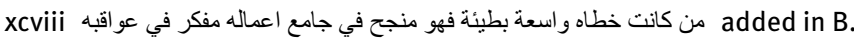

xcix, omitted in $B$.

C سريعة قصيرة B.

ci شكس omitted in B.

cii الامور B. 
ciii سيّء النيّة remitted in B. الامور repeated in B (dittography).

civ The phrase و المعتدل الفهم الجيّّ الطبع ene corresponding to the title of one of the ideal portrait in Rāzì (see supra section IV.2), is entirely missing from the text of the Berlin manuscript.

CV هو أن يكون omitted in B.

cvi من كان لحمُ ان مهنه B.

cvii الخد B.

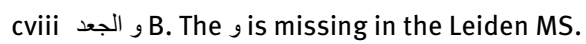

cix متوسنطاً omitted in B.

CX الغورة B.

Cxi في العظم Cxitted in B.

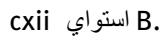

cxiii مائل الأكتاف النئ omitted in B.

cxiv صورته B. A (modern ?) correction mark in the form of two parentheses around the rā’ is visible.

CXV MSS : صفاو خفان

Cxvi دقته B.

Cxvii بسط

Cxviii مائلا B.

cxix و والضحك B omitted in B.

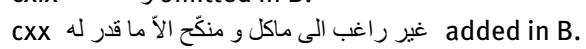

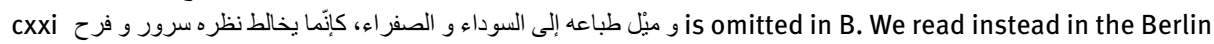

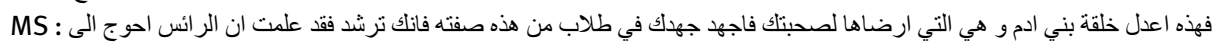

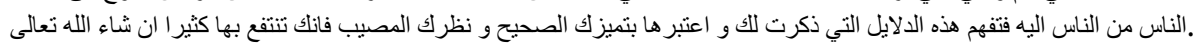
In the Leiden MS, this element comes on fol. 99r, directly before the title of the 'gate' on Hygiene ("Fì al-rutba al-husnā fĩ tadbīr al-jism," literally "On the good preservation in the bodily regime"). It appears in Book VII, "On Wars" (foll. 95r-103r) after the vizier's portrait (95r ult.-96v), the 'gate' on the scribes (foll. 98r-98v, cf. Book V of Sirr-Badawī, p. 144), that on the administrators and the tax-collectors (foll. 98v-99r, cf. Book VII of Sirr-Badawī, p. 146). The interpolation of an element of the Physiognomy at this place in the Leiden manuscript may be the result of a wrongly inserted marginalia, but the issue deserves further comparisons with the other Short Form manuscripts. In the Long Form and the London Physiognomy, this element forms part of the Physiognomy, cf. Sirr-Badawi 118.15-16 and London Physiognomy, supra Table 1, section [I.].

\section{Bibliography}

Abdel-Messih, E. 1969. "Al-Farabi, livre de concordance entre les opinions des deux sages, le divin Platon et Aristote". In: Parole de l'Orient 5, 305-358.

Abū Ma'shar. n.d. [ca. 1920?]. Kitāb al-Muhaqqiq al-Mudaqqiq al-Yūnānī, ed. 'T̄sā al-Bābī al-Ḥalabī et al. Cairo.

Anawati, G. 1955. "Sources grecques de la philosophie politique de l'Islâm”. In: La Revue du Caire 34, 60-70.

André, J. 1981. Anonyme Latin. Traité de Physiognomie, Paris.

Aouad, M. 1989. “La Théologie d’Aristote et autres textes du Plotinus Arabus”. In: R. Goulet (ed.), Dictionnaire des Philosophes Antiques, vol. 1, 541-590.

Arberry, A. J. 1950. The Spiritual Physick of Rhazes. London.

Arberry, A. J. 1953. “More Niffar””. In: Bulletin of the School of Oriental and African Studies 15(1), 29-42.

[Avicenna], al-Shaikh al-Ra' is Abu Ali Al-Husain Bin 'Abdullah Bin Sina. 1982. Al-Qanun Fi'l-Tibb.

Book I. New Delhi. 
Badawī, 'Abd al-Raḥmān. 1954. al-Ușūl al-Yūnāniyya li-l-Nazariyyaāt as-Siyāsiyya fĩ al-Islām, Pars Prima, Cairo.

Badawī, 'Abd al-Raḥmān. 1954. Sirr al-Asrār: see Badawī, 'Abd al-Raḥmān. 1954. al-Ușūl al-Yūnāniyya li-l-Nazariyyaāt as-Siyāsiyya fĩ al-Islām.

Balīnas al-Ḥakīm. 1979. Sirr al-Khalīqa wa șan'at al-țabī'a (Pseudo-Apollonios von Tyana, Büch über das Geheimnis der Schöpfung und die Darstellung der Natur), ed. U. Weisser, Aleppo.

al-Bayhaqī, Ẓahīr al-Dīn. 1935. Tatimmat Șiwān al-ḥikma, ed. M. Shafī‘, Lahore.

al-Bayhaqī, Ẓahīr al-Dīn. 1946. Ta'rīkh ḥukamā' al-islām [=Tatimmat Șiwān al-ḥikma], ed. M. Kurd 'Alī, Damascus.

al-Bayhaqī, Ẓahīr al-Dīn. 1994. Tatimmat Șiwān al-ḥikma, ed. R. 'Ajam, Dār al-Fikr al-Yūnānī.

Beeston, A. F. L. 1954-1956. “An Ancient Druze Manuscript”. In: The Bodleian Library Record 5, 285-290.

Bergsträsser, G. 1925. Hunain ibn Ishāq. Über die syrischen und arabischen Galen-Übersetzungen. Leipzig.

Bizzarri, H. 0. 2010. Secreto de los secretos. Poridat de las poridades: Versiones castellanas del Pseudo-Aristóteles Secretum Secretorum. València.

Brockelmann, C. 1898. "Beiträge zur Geschichte der arabischen Sprachwissenschaft". Zeitschrift für Assyriologie 12, 29-46.

Brugman, J., and Drossart Lulofs, H. J. 1971. Aristotle. Generation of the Animals, The Arabic Translation Commonly Ascribed to Yahya ibn al-Bitriq. Leiden.

Cottrell, E. (in press). "An Arabic Manuscript of the Pseudo-Hippocratic Letters," forthcoming in the proceedings of the XXIXth International Conference on the History of Arabic Sciences [University of Aleppo, 3rd-5th Nov. 2009].

Cottrell, E. 2016. "Sïrat Buqrāṭ̂̃ al-mașādir al-'arabiyya: ḥayātuhu, rasā’iluhu, wa al-qasam al-mašhūr [The Life of Hippocrates in Arabic Sources: Biography, Letters, and the Famous Oath]" [in Arabic]. In: P. Koetschet \& P. Pormann (eds.), La Construction de la Médecine arabe médiévale. Beirut, 131-142.

Daiber, H. 1986. The Ruler as Philosopher. A new interpretation of al-Färäbì's view. Leiden.

Daiber, H. 1991. "The Ismaili Background of Fārābī’s Political Philosophy. Abū Ḥātim ar-Rāzī as a forerunner of Fārābī”. In: U. Tworuschka (ed.), Gottes ist der Orient - Gottes ist der Okzident, Festschrift für Abdoldjavad Falaturi zum 65. Geburtstag. Köln, 143-150.

Daiber, H. 2009. Catalogue of Microfilms and Offprints from Arabic Manuscripts in Manuscripts Libraries in the Daiber Collection IV (privately published by the author; available at the Library of Leiden University).

De Smet, D. 1995. La Quiétude de l'Intellect. Néoplatonisme et gnose ismaélienne dans l'œuvre de Hamîd ad-Dîn al-kirmânî ( $X^{\mathrm{e}} / X l^{\mathrm{e}}$ s.). Leuven.

De Smet, D. 2012. Les Epîtres des Druzes, Leuven.

Dunlop, D. M. 1959. “The Translations of Al-Bițrīq and Yaḥyā (Yuḥannā) b. al-Biṭrīq". In: Journal of the Royal Asiatic Society 91(3-4), 140-150.

Endress, G. 1966. Die arabischen Übersetzungen von Aristoteles' Schrift De Caelo. PhD dissertation, University of Frankfurt.

Ess, J. (van). 1991-1997. Theologie und Gesellschaft. Berlin.

Fahd, T. 1966. La Divination arabe, Leiden.

Filius, L. S. 1999. The Problemata Physica, Attributed to Aristotle: The Arabic Version of Hunain Ibn Ishāq and the Hebrew Version of Moses Ibn Tibbon. Leiden.

Förster, R. 1893. Scriptores Physiognomici, Leipzig.

Forster, R. 2006. Das Geheimnis der Geheimnisse. Die arabischen und deutschen Fassungen des pseudo-aristotelischen Sirr al-asrär/Secretum Secretorum, Wiesbaden.

Gaster, M. 1908. "The Hebrew version of the "Secretum Secretorum." A Mediæval treatise ascribed to Aristotle. II. Translation". In: Journal of the Royal Asiatic Society 40(1), 111-162 and 40(4), 1065-1084. 
Gätje, H., and Daiber, H. 1965. "Die arabische Handschrift Chester Beatty 4183 und das Kitāb Sirr al-Asrār”. In: Der Islam 42, 71-78.

George, A. 2010. The Rise of Islamic Calligraphy. London.

Ghaly, M. 2009. "Physiognomy: A Forgotten Chapter of Disability in Islam. The Discussion of Muslim Jurists". Bibliotheca Orientalis 66(3-4), 162-198.

Ghersetti, A. 1999. Il Kitāb Arisțātāalīs al-faylasūf fĩ l-firāsa nella traduzione di Ḥunayn b. Ishạāq. Rome-Venice.

Ghersetti, A. 2007a. "The Istanbul Polemon (TK Recension): Edition and Translation of the Introduction”. In: S. Simon, Seeing the Face, Seeing the Soul. Polemon's Physiognomy from Classical Antiquity to Medieval Islam. Oxford, 465-486.

Ghersetti, A. 2007b. "The Semiotic Paradigm: Physiognomy and Medicine in Islamic Culture". In: S. Swain, Seeing the Face, Seeing the Soul. Polemon's Physiognomy from Classical Antiquity to Medieval Islam. Oxford, 281-308.

Grignaschi, M. 1967. “Le Roman épistolaire classique”. Le Muséon 80,1-64.

Grignaschi, M. 1976. “L’Origine et les métamorphoses du Sirr al-Asrār”. In: Archives d'histoire doctrinale et littéraire du Moyen Âge 43, 7-112.

Grignaschi, M. 1982. "Remarques sur la formation et l'interprétation du Sirr al-Asrār". In: W. F. Ryan \& C. B. Schmitt, Pseudo-Aristotle. The Secret of Secrets, Sources and Influences. London, 3-33. Gorak, J. 1991. The Making of the Modern Canon. Genesis and Crisis of a Literary Idea. London. Gutas, D. 1986. "The Spurious and the Authentic in the Arabic Lives of Aristotle". In: J. Kraye, C. B. Schmitt, \& W. F. Ryan (eds.), Pseudo-Aristotle in the Middle Ages: The theology and other texts. London, 15-36.

Gutas, D. 2012. “Platon: Tradition arabe”. In: R. Goulet (ed.), Dictionnaire des Philosophes Antiques, vol. Va. Paris, 852-853.

Hoyland, R. 2006. "Polemon's encounter with Hippocrates and the Status of Islamic Physiognomy". In: Jerusalem Studies in Arabic and Islam 32, 311-326.

Hoyland, R. "A New Edition of the Leiden Polemon". In: S. Swain (ed.), Seeing the Face, Seeing the Soul. Polemon's Physiognomy from Classical Antiquity to Medieval Islam. Oxford, 329-342.

Ḥunayn ibn Ishāq. 1970. Libro de los Buenos Proverbios, ed. H. G. Sturm, The Libro de los Buenos Proverbios. A Critical Edition. Lexington.

Ḥunayn ibn Isḥāq. 1985. Ādāb al-falāsifa, ed. 'Abd al-Raḥmān Badawi. Kuwait.

Ibn Abī Ușaybi'a, 1882-1884. 'Uyūn al-anbā fĩ țabaqāt al-ațibbā', ed. A. Müller. Königsberg. Ibn Juljul. 1955. Ṭabaqāt al-ațibbā' wa-l-ḥukamā', ed. Fū'ad Sayyid. Cairo.

Ibn al-Nadīm. 2009. Fihrist, ed. Aymān Fū'ad Sayyid. London.

Ibn al-Nadīm. 1971. Fihrist, ed. Riḍa Tajaddod. Tehran.

Jorati, H. 2014. Science and Society in Medieval Islam: Nasir al-Din Tusi and the Politics of Patronage. New Haven.

Kahl, 0. 2015. The Sanskrit, Syriac and Persian Sources in the Comprehensive Book of Rhazes. Leiden.

Kasten, L. A. W. 1957. Seudo-Aristóteles, Poridat de las Poridades. Madrid.

al-Kirmānī, Ḥamīd al-Dīn. 1977. al-Aqwāl al-Dhahabiyya, ed. Șahlān al-Sāwī. Tehran.

Kraus, P. 1937. "Kitāb al-Akhlāq li-Jālīnūs”. In: Majallat Kulliyyat al-Ādāb/Bulletin of the Faculty of Arts [Cairo], 5(1), 1-51.

Kruk, R. 1978. The Arabic version of Aristoteles' Parts of Animals (books XI-XIV of Kitäb al-Hayawān). A Critical Edition with Introduction and Commentary. Leiden.

Legge, F. 1921. Philosophumena or the Refutation of All Heresies formerly attributed to Origen, but now to Hippolytus.... London.

Leigh, R. A. 2013. On Theriac to Piso. Attributed to Galen. PhD dissertation, University of Exeter.

Manzalaoui, Mahmoud. 1974. "The Pseudo-Aristotelian Kitāb Sirr al-Asrār. Facts and Problems". In: Oriens 23/24, 147-257. 
Mardam Bak, Khalīl. n. d. Dīwān 'Alī ibn al-Jahm. Beirut.

Meredith-Owens, G. M. 1955-1956. "A Tenth-Century Arabic Miscellany”. In: British Museum Quarterly 20, 33-34.

Meyerhof, M. 1948. "Alī al-Bayhaqī’s Tatimmat Șiwān al-Ḥikma”. In: Osiris 8, 122-217.

Mohaghgheg, M. 2001. Risālat Ḥunayn bni Isḥāq ilā 'Alī bnī Yahyā fĩ dhikr mā turjima min kutub Jālīnūs. Tehran.

Montgomery, J. E. 2013. Al Jahiz: In Praise of Books. Edinburgh.

Moraux, P. 1951. Les Listes anciennes des ouvrages d'Aristote. Louvain.

Mourad, Y. 1939. La Physiognomonie arabe et le Kitāb al-Firāsa de Fakhr al-Dīn al-Rāzī. Paris.

Peters, F. E. 1968. Aristoteles Arabus. The Oriental Translations and Commentaries of the Aristotelian Corpus. Leiden.

Pingree, D. 1970. “Abū Ma'shar”. In” Dictionary of Scientific Biography. New York, vol. 1, 36-37.

Plessner, M. 1925. "Review of A.S. Fulton et al., Secretum Secretorum". In: Orientalistiche Literaturzeitung 11/12, 912-920.

Pormann, P. 2004. The Oriental Tradition of Paul of Aegina's Pragmateia. Leiden.

al-Rāzī, Abū Bakr. 1987. al-Manșūrī fĩ al-Ṭibb, ed. Ḥāzim al-Bakrī al-Șiddiqī. Kuwait.

Repath, I. 2007. "The Physiognomy of Adamantius the Sophist”. In: S. Swain (ed.), Seeing the Face, Seeing the Soul. Polemon's Physiognomy from Classical Antiquity to Medieval Islam. Oxford, 487-547.

Richter-Bernburg, L. 1969. Eine arabische Version der pseudogalenischen Schrift De Theriaca ad Pisonem. PhD dissertation, University of Göttingen.

Rodionov, M. A. 1995. Rasā'il al-hikma. Saint-Petersburg.

Rosenthal, F. 1947. The Technique and Approach of Muslim Scholarship. Rome.

Rosenthal, F. 1974. "Plotinus in Islam: The Power of Anonymity". In: Atti del Convegno Internazionale sul Tema: Plotino e il Neoplatonismo in Oriente e in Occidente. Rome, 437-446.

Rudolph, U. 1989. Die Doxographie des Pseudo-Ammonius. Stuttgart.

Salvador Martínez, H. 2010. Alfonso X, the Learned: A Biography. Leiden.

Savage-Smith, E. (ed.). 2003. Magic and Divination in Early Islam. Aldershot.

Sezgin, F. (ed.). 1999. Abū Nașr (...) al-Fārābī. Various philosophical treatises selected and reprinted. Frankfurt.

Sezgin, F. 1974. Geschichte des Arabischen Schriftums. Band 5. Mathematik bis ca. 430 H. Leiden. al-Shahrazūrī, Shams al-Dīn. 1976. Nuzhat al-Arwāh, ed. S. Khurshīd Ạ̣mad. Hyderabad.

Soudavar, A. 1999. "The Concepts of 'al-Aqdamo Asahh' and 'Yaqin-e Sābeq', and the Problem of Semi-Fakes”. In: Studia Iranica 28(2), 255-273.

Spitzer, A. I. 1982. "The Hebrew translation of the Sod ha-Sodot and its place in the transmission of the Sirr al-Asrär". In: W. F. Ryan \& C. B. Schmitt, Pseudo-Aristotle. The Secret of Secrets. Sources and Influences. London, 34-54.

Steele, R. (ed.). 1920. Roger Bacon. Secretum Secretorum. Oxford.

Steigerwald, D. 1999. “La pensée d'al-Fārābī (259/872-339/950): son rapport avec la philosophie ismaélienne". In: Laval Théologique et Philosophique 5(3), 455-476.

Swain, S. 2006. "Beyond the limits of Greek biography: Galen from Alexandria to the Arabs". In: B. McGing \& J. Mossman (eds.), The Limits of Ancient Biography. Swansea, 395-433.

Swain, S. (ed.). 2007. Seeing the Face, Seeing the Soul. Polemon's Physiognomy from Classical Antiquity to Medieval Islam. Oxford.

Tabbaa, Y. 1991. "The Transformation of Arabic Writing: Part I, Qur’ānic Calligraphy”. In: Ars Orientalis 21, 119-148.

Tamer, G. 2001. Islamische Philosophie und die krise der Moderne. Leiden.

Tamer, G. 2004. "Politisches Denken in pseudoplatonischen arabischen Schriften," Mélanges de l'Université Saint-Joseph 57, 303-335.

Tannery, P. 1844. “Notice des Fragments d'Onomatomancie arithmétique”. In: Notices et Extraits de la Bibliothèque Nationale 31(2), 231-260. 
Thomann, J. 2003. “La tradition arabe de la physiognomonie d'Aristote”. In: R. Goulet (ed.), Dictionnaire des philosophes antiques, Paris: CNRS Editions, Supplement I, 496-498

Turaykī, A. 1983. Sirr al-asrār li-ta'sīs al-siyāsa wa-tartīb al-riyāsa, li-lkhwān al-Ṣafä' wa-Khillān al-Wafä', second edition. Beirut.

Ulrich, E. 2002. "The Notion and Definition of Canon". In: L. M. McDonald \& J. A. Sanders, The canon debate: On the origins and formation of the Bible. Peabody.

Van Bladel, K. 2004. "The Iranian Characteristics and forged Greek Attributions in the Arabic Sirr al-Asrār”. Mélanges de l'Université Saint-Joseph 57, 151-172.

Van Bladel, K. 2009. The Arabic Hermes. Oxford.

Verdenius, A. A. 1917. Jacob van Maerlant's Heimelijkheid der Heimelijkheden. Amsterdam.

Wallis Budge, E. A. 1896. The Life and Exploits of Alexander the Great Being a Series of Translations of the Ethiopic Histories of Alexander by the Pseudo-Callisthenes and Other Writers. London.

Wallis Budge, E. A. 1913. Syrian Anatomy, Pathology and Therapeutics, or: The Book of Medicine. London.

Walzer, R. 1985. Al-Farabi on the Perfect State. Oxford.

Weisser, U. 1980. Das „Buch über das Geheimnis der Schöpfung“ von Pseudo-Apollonios von Tyana. Berlin.

Wickens, G. M. 1962. "Nasir al-Din Tusi on the Fall of Baghdad: a Further Study”. Journal of Semitic Studies 7(1), 23-35.

Witkam, J. J. 2007. Inventory of the Oriental Manuscripts of the Library of the University of Leiden, vol. 1, Or. 1-Or. 1000. Leiden.

Zimmermann, F. 1986. "The Origins of the So-Called Theology of Aristotle". In: Kraye et al., PseudoAristotle in the Middle Ages. London, 110-240.

Zysk, K. G. 2015. The Indian System of Human Marks. Leiden. 
